\title{
The Economic Origins of the Seventh Amendment
}

\author{
Matthew P. Harrington *
}

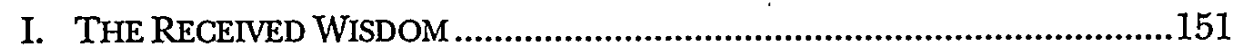

II. THE “VERY ESSENCE OF LIBERTY” ......................................................155

III. THE JURY IN THE COLONIES ............................................................160

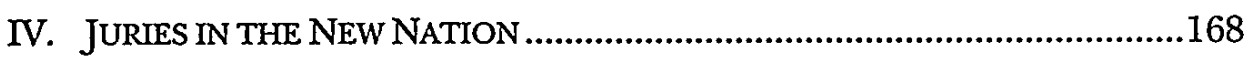

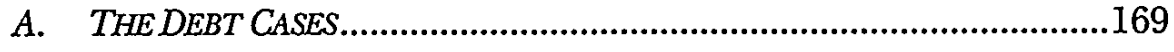

B. STATE COURT JURIES AND PRIZE CASES .........................................176

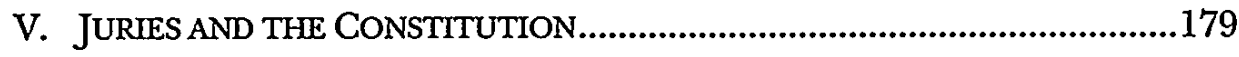

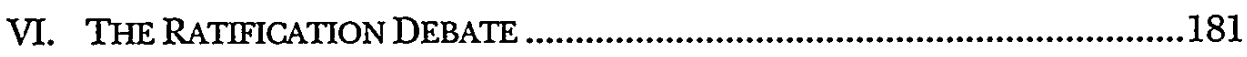

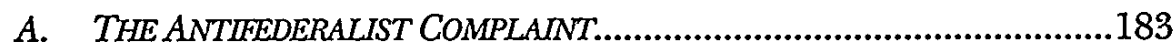

1. Protection Against Abuse by Government Officials ..............185

2. Protection Against Unjust Legislation .................................186

3. Protection Against Biased or Corrupt Judges........................187

4. Protection of Economic Rights ..........................................188

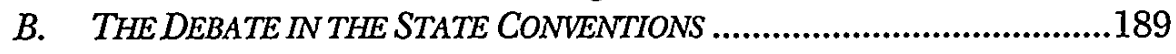

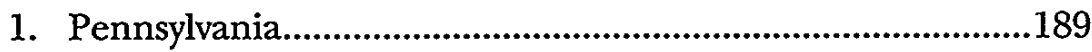

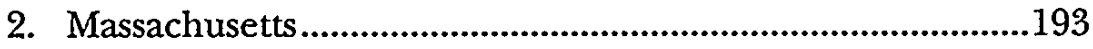

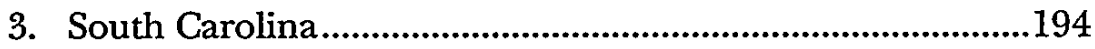

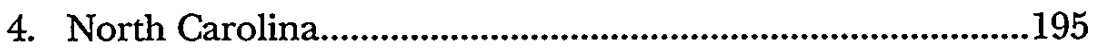

5. Virginia.............................................................................196

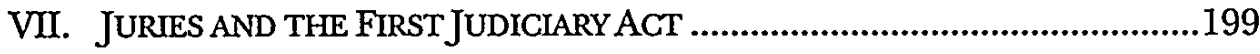

A. CREATING THE COURTS .............................................................200

B. TRIAL BY JURY AND APPEALS OF FACT............................................203

C. ADMIRALTY, EQUTTY, AND THE COMMON LAW.................................204

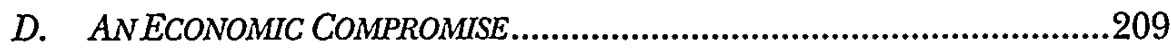

Assistant Dean, George Washington University Law School. S.J.D. (Pennsylvania), J.D. (Boston), B.Th. (McGill). 
VIII. THE JUDICIARY BILL AND MADISON'S AMENDMENTS ........................210

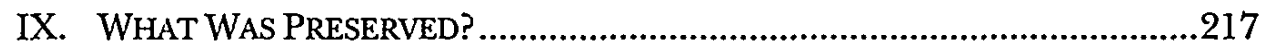

X. Of Justice StORY AND His CRITICS.............................................229 
In Suits at common law, where the value in controversy shall exceed twenty dollars, the right of trial by jury shall be preserved....

\section{U.S. CONST. amend. VII.}

For over two hundred years, Americans have remained devoted to the institution of trial by jury. Indeed, at this point in its history, the jury is an almost uniquely American institution-at least in civil cases. It has been largely abandoned almost everywhere in the world, even in England itself. ${ }^{1}$ In the United States, however, the jury continues to occupy a special place in the judicial process. This is in spite of the fact that civil juries have repeatedly been the object of attacks by critics who regard them as an obstacle to efficiency in the disposition of cases, ${ }^{2}$ irrational in their decisionmaking process, ${ }^{3}$ or incompetent to determine the increasingly complex legal and scientific issues that are more frequently part of modern civil litigation. ${ }^{4}$

One of the more difficult questions facing those engaged in complex litigation today is whether a particular cause of action is triable by jury. This is because in deciding whether to empanel a jury in a particular case, federal courts are limited to applying a "historical test." This test requires that courts look to the character of the plaintiff's cause of action and decide whether it is of a type that would have been tried in the common law courts in England in 1791 . If so, the action is triable by a jury today. ${ }^{5}$ As the Supreme Court has

1. "In England, a series of restrictions reduced the use of juries from one hundred percent of civil trials in 1854 to two percent a century later." Marc Galanter, The Civil Jury as Regulator of the Litigation Process, 1990 U. CHI. LEGAL F. 201, 202 (citing SIR PATRICK DEVLIN, TrIAL BY JURY 129-33 (1966)); see also J.H. BAKER, AN INTRODUCTION TO ENGLISH LEGAL HISTORY 109 (1990); James Driscoll, The Decline of the English Jury, 17 AM. Bus. L.J. 99, 99 (1979). Civil juries are similarly scarce in Canada and Australia. Galanter, supra, at 202-03.

2. See, e.g., David W. Peck, The Future of the Trial Lawyer, 40 J. AM. JUDICATURE. Soc. 38, 42 (1956) (accusing the civil jury of being the "bottleneck" which is "the cause of all the delay which has come to characterize the courts").

3. See, e.g., John G. Kester, Are Lawyers Becoming Public Enemy Number One?, GT. REV., Spring 1984, at 4, 8 (complaining that "[c]ivil litigation is often an opportunity for juries to play Robin Hood and redistribute wealth"); see also JEROME FRANK, COURTS ON TRIAL: MYTH AND REALITY IN AMERICA JUSTICE 1008-45 (1950) (accusing the jury of being "irrational" in its decision-making)

4. See, e.g., Abraham Chayes, The Role of the Judge in Public Law Litigation, 89 HARV. L. REV. $1281,1303 \mathrm{n} .93$ (1976) (" $[\mathrm{T}] \mathrm{he}$ impulse that accounts for the volume of personal injury litigation is not the demand of the parties for an adjudication under law, but the plaintiff's desire for access to a jury where the governing legal rules are at odds with popular sentiment.").

5. See, e.g., Balt. \& Carolina Line, Inc. v. Redman, 295 U.S. 654, 657 (1935) (noting that the right of trial by jury "is the right which existed under the English common law when the [Seventh] Amendment was adopted"); Dimick v. Schiedt, 293 U.S. 474, 476 (1935) ("In order to ascertain the scope and meaning of the Seventh Amendment, resort must be had to the 
defined the test, a court must first ask "whether we are dealing with a cause of action that either was tried at law at the time of the founding or is at least analogous to one that was." If the claim would have been tried at law, the court must then ask "whether the particular trial decision must fall to the jury in order to preserve the substance of the common-law right as it existed in 1791."

The problem with the Supreme Court's historical test is that it is based on a fundamental misconception about the purposes of the Seventh Amendment. In other words, to ponder whether English courts in 1791 would have tried a particular cause of action to a jury is to ask the wrong question. This is because the historical test is entirely without warrant in the historical record. In fact, there is no evidence that the framers of the Seventh Amendment intended to "preserve" for all time the right to jury trial as it existed in England in 1791. Indeed, there is no evidence that the framers of the Seventh Amendment ever agreed on a substantive rule at all. On the contrary, it is far more likely that the Seventh Amendment was precatory in nature-designed to enshrine a commitment to general principles in the constitutional text-without codifying a black-letter rule setting forth when juries would be required in particular cases. ${ }^{8}$

Over the years, the Supreme Court has erred by reading far too much into the text of the Seventh Amendment and failing to take into account the fact that the amendment was itself the result of a long process of conflict and compromise. Rather than representing a consensus on the scope of the right to a civil jury trial, the Seventh Amendment was really the climax of the long struggle over the right of the jury to find both law and fact in civil cases, and was designed to achieve a compromise between those who believed that the jury should have unfettered power to decide both law and fact and those who sought to allow judges to impose some limits on the jury's power to decide the whole of a case. ${ }^{9}$

In the eighteenth century, juries had the power not just to find fact, but to say what the law should be. This meant that juries were empowered to not only declare "what happened," but what rules of law should apply. ${ }^{10}$ In the

appropriate rules of the common law established at the time of the adoption of the consitutional provision in 1791."). The historical test has its origins in an opinion rendered by Justice Joseph Story while on circuit in 1812. See United States v. Wonson, 28 F. Cas. 745, 750 (C.C.D. Mass. 1812) (No. 16,750) (holding that federal courts should rely on English law to determine whether the First Amendment requires a jury in any particular case).

6. Markman v. Westview Instruments, Inc., 517 U.S. 370, 376 (1996).

7. Id.

8. See infra text accompanying notes 322-62 (describing Congress's attempts to fashion a right to jury trial in federal court).

9. Id.

10. The law-finding function of the English and American jury is set forth in more detail in Matthew P. Harrington, The Law-Finding Function of the American Jury, 1999 WIS. L. REV. 377 [hereinafter Harrington, Law-Finding]. 
years preceding the American Revolution, the jury's ability to say what the law should be was considered a sure defense against royal oppression. English and American juries repeatedly stood as a barrier to arbitrary rule by the Crown, protecting the citizenry against abuses by royal officials. ${ }^{11}$ After the Revolution, however, unrestrained juries created serious obstacles to the new nation's commercial and economic development. Using their lawfinding function, confederation era juries often upset long-held commercial expectations by refusing to bring in verdicts in favor of British creditors in debt cases or by condemning property owned by allies in numerous prize cases brought during the revolutionary war. Foreign governments repeatedly complained about the mistreatment of their citizens by American juries, but attempts to control jury verdicts went for naught. ${ }^{12}$ Political and commercial elites soon worried that unrestrained juries would irrevocably damage the new nation's standing in the world. While some political leaders claimed that arbitrary jury verdicts would bring the nation into war against its will, a far more pressing concern was that the jury's law-finding function had the potential to damage the nation's commercial reputation. Economic interests were convinced that foreigners would not invest in a society whose legal institutions appeared arbitrary or capricious. They saw the jury as an obstacle to economic progress and sought some means by which its power might be curtailed. This concern was one part of the growing unease with populist government in general, and helped convince many that a new, more predictable, legal regime was necessary if the new nation was to survive. ${ }^{13}$

The absence of any provision for civil jury trials in the Constitution moved concerns about juries to the forefront of the debate over the future of the new nation. Already suspicious about the scope and breadth of the powers to be given the new government, antifederalists complained that the framers of the Constitution had debased one of the most cherished defenses against governmental oppression. Supporters of the Constitution attempted to rebut this argument by asserting that the right to a jury trial in the several states differed so greatly that it was "too difficult" to draft a single constitutional provision that would adequately address the diversity of jury practice which then existed. The opposition was so intense that it forced supporters of the Constitution to agree to propose amendments once the new Congress convened. ${ }^{14}$

In the end, it was left to the first Congress to address the ongoing conflict over jury trials. In framing the first Judiciary Act, Congress struck a

11. 3 WilliaM BLACKSTONE, COMMENTARIES $* 379$.

12. See infra text accompanying notes $104-49$ (describing difficulties involving foreign citizens in obtaining favorable verdicts from American juries).

13. See infra text accompanying notes $145-49$ (discussing political and commercial leaders' concerns about the powers of unfettered juries).

14. See infra text accompanying notes 163-267 (describing antifederalist complaints about lack of guarantees for civil juries in the text of the Constitution). 
compromise along economic lines, allowing juries to determine cases in which the national government was indirectly concerned, while eliminating juries in cases that had a direct impact on the nation's revenue and commerce. Though imperfect in many ways, this trade-off accommodated the strong federalists' desire to limit the jury's law-finding function, while allowing weaker federalists to acquiesce in the creation of an extensive system of lower federal courts. As a result, by the time James Madison brought forth his amendments to the Constitution in June 1789, the controversy over the right to trial by jury in civil cases had already been resolved. Although most antifederalists (and even some federalists) believed that some explicit protection for civil juries needed to be enshrined in the constitutional text, the diversity of state practice made agreement on any specific formula impossible. Relying on the compromise already embodied in the Judiciary Act, the first Congress merely recommended that the right to trial by jury be "preserved."

Consequently, the Supreme Court's reliance on the historical test has become an unnecessary impediment to the implementation of the Seventh Amendment's jury trial guarantee. Indeed, attempting to discern a substantive rule in the text of Seventh Amendment without reference to the economic compromise contained in the first Judiciary Act is but an idle exercise. Although the Amendment was designed to reinforce the founders' commitment to the principle of trial by jury in civil cases, it did not define the precise scope of the right. The most that could be said of the Amendment is that it was intended to ensure that the people would be adequately represented in all the branches of their government. The Amendment also obliged the courts of the republic to respect the verdict of the jury in those cases in which juries were ultimately empaneled. It did not, however, attempt to define either the types of cases in which juries were required or the range of issues that must be put to them. In the end, the Seventh Amendment was the result of political calculation. It was designed to neutralize antifederalist complaints, while at the same time avoiding the need to say specifically what rights were actually to be enforced. ${ }^{16}$

This Article will show that the Supreme Court's historical test does not accord with the history surrounding the adoption of the Seventh Amendment. First, it will examine the origins of the struggle over the jury's law-finding function in both England and the colonies and discuss the consequences of the law-finding function for the adjudication of civil cases in the early national period. Second, it will describe how the problems in foreign relations and economic development caused by the widespread use

15. See infra text accompanying notes 276-319 (discussing economic compromise reached in the first Judiciary Act).

16. See infra text accompanying notes 363-422 (discussing Madison's sources and motives in drafting the Seventh Amendment). 
of juries led to a commitment on the part of many of the founders to seek some means by which civil juries could be controlled. Third, it will demonstrate that the Seventh Amendment was never meant to stand on its own. Rather, it will show that the Seventh Amendment can be properly viewed only in the context of the Judiciary Act of 1789 , which was itself a structural compromise based on economic considerations.

This Article will conclude by showing that the Supreme Court's reliance on the so-called "historical test" is actually ahistorical, and that the Seventh Amendment imposes no requirement that juries in civil cases be tied to pre1791 English practice. On the contrary, an examination of the circumstances surrounding the passage of the Amendment leads to the conclusion that the first Congress intended to allow the right to a civil jury to develop in accordance with a functional approach that would take into account the limitations and abilities of the jury as well as the types of cases in which such juries might be empaneled.

\section{THE RECEIVED WISDOM}

Over the years, courts and commentators have struggled to determine precisely what Madison had in mind in proposing the Seventh Amendment, and what, particularly, the Amendment sought to "preserve." The Supreme Court has traditionally held the view that the Seventh Amendment was designed to "preserve" the right to trial by jury "which existed under the English common law when the amendment was adopted. ${ }^{.17}$ In the Court's view, the Amendment imposes a historical test. In determining whether a jury should be empaneled in a particular case, a trial court must be guided by the practice of English courts in 1791: "If a jury would have been impaneled in this kind of case in 1791 English practice, then generally a jury is required by the seventh amendment. If the case is one of those in which a jury would not have sat-in England in 1791-then none is required ...."18 Under the historical test, therefore, "English practice in 1791 determines all." 19

The origin of the Supreme Court's jurisprudence in this area can be traced to Justice Story's opinion in United States $v$. Wonson. ${ }^{20}$ Wonson involved a suit by the United States to collect a penalty under the Embargo Act of 1808. ${ }^{21}$ After a district court jury found for the defendant, the United States attempted to obtain a second jury trial in the circuit court. ${ }^{22}$ Story held that

17. Markman v. Westview Instruments, Inc., 517 U.S. 370, 376 (1996) (quoting Balt. \& Carolina Line, Inc. v. Redman, 295 U.S. 654, 657 (1935)).

18. Charles W. Wolfram, The Constitutional History of the Seventh Amendment, 57 MINN. L. REV. 639,640 (1973).

19. Id.

20. 28 F. Cas. 745 (C.C.D. Mass. 1812) (No. 16,750).

21. Act of Jan. 9, 1808, 2 Stat. 453 (1808).

22. Wonson, $28 \mathrm{~F}$. Cas. at 745. 
the Seventh Amendment's "re-examination clause" prohibited an appellate court from reviewing facts found by a lower court except in accordance with the common law. ${ }^{23}$ Story noted that New England practice permitted subsequent jury trials in common-law courts, but he nonetheless rejected the practice on the federal level. ${ }^{24}$ It was "[b]eyond all question," Story argued, that "the common law here alluded to [in the re-examination clause] is not the common law of any individual state, (for it probably differs in all), but it is the common law of England, the grand reservoir of all our jurisprudence. ${ }^{25}$ Story then asserted in dicta that the test for determining whether a jury trial is available is determined by English, rather than American, precedents. ${ }^{26}$

This historical test is seductive in its simplicity, however. In the early years, at least, the apparent similarity between common-law actions in England and America might have allowed for a relatively straightforward application of the test, because much of the litigation would have involved common law contract or real property actions. ${ }^{27}$ Yet, with the merger of law

23. Id. at 750.
24. Id. at 748.
25. Id. at 750 .
26. Id. at 750 . The Supreme Court itself has consistently reaffirmed the rule expounded in Wonson. For an example of this, see Thompson v. Utah, 170 U.S. 343, 350 (1898). Consequently, there are two significant facts accompanying this conclusion. The first is that the right to a jury trial is dependent on English practice. Although a few cases have hinted that American practice might be relevant to the discussion, none has ever authorized a substantial departure from the English rules. See, e.g., Cont'l Ill. Nat'l Bank \& Trust Co. v. Chi., R.I. \& Pac. Ry. Co., 294 U.S. 648,669 (1935) (“[The Seventh Amendment's] guaranty has always been construed to mean a trial in the mode and according to the settled rules of the common law, including all the essential elements recognized in this country and England when the Constitution was adopted."); Patton v. United States, 281 U.S. 276, 288 (1930) ("That [the Seventh Amendment] means trial by jury as understood and applied at common law, and includes all the essential elements as they were recognized in this country and understood in England when the Constitution was adopted, is not open to question."). Secondly, the historical test is "temporally static." Wolfram, supra note 18 , at 641 . The governing principles are those which were in effect at the time the Amendment was adopted in 1791. See Ross v. Bernhard, 396 U.S. 531, 534 (1970) (basing its holding, to some extent, on a reference to the common law at the time of the Amendment's adoption); Dimick v. Schiedt, 293 U.S. 474, 476 (1935) (resorting to the common-law rules already established in 1791).

27. For example, between 1785 and 1800 , at least $50.6 \%$ of reported cases in the King's Bench involved contract claims, such as suits for assumpsit, debt, or covenant. Douglas King, Complex Civil Litigation and the Seventh Amendment Right to a Jun Trial, 51 U. CHI. L. REV. 581, 599 (1984). Another 16\% involved actions concerning real property, such as claims in ejectment or trespass. "Tort" claims, such as trespass on the case, trover, or detinue, made up another $10 \%$. $I d$. The remainder of the cases involved replevin or actions quo warranto. Id.

The similarity was illusory to some extent, however. The common law had been introduced at different times in each of the colonies so that, by the founding of the Republic, it was often difficult to say how much of the common law was in force in any particular state. Moreover, while there was some similarity in common-law practice generally, process and procedure varied greatly. Such differences were instrumental in convincing Congress to order that "the forms of writs and executions, ... and modes of process" in the federal courts be the 
and equity in the Federal Rules of Civil Procedure ${ }^{28}$ and the increase in new statutory causes of action, modern civil litigation has become increasingly complex and often bears little relationship to litigation in the common-law courts of the 1790s. Extinguishing the line between equity and common law, ${ }^{29}$ allowing for joinder of multiple claims and parties, ${ }^{30}$ and eliminating the requirement that parties plead down to a single issue ${ }^{31}$ has meant that even the most routine action for damages can involve a dizzying number of issues and problems for juries to resolve. The appearance of new remedies created by various federal statutes which do not easily fit within the old common-law/equity dichotomy has further complicated attempts to apply the historical test. ${ }^{32}$ Modern securities, antitrust, and patent cases have become nightmares of complexity, often involving multiple (and sometimes inconsistent) claims, large numbers of plaintiffs and defendants, and reams of discovery. Consequently, courts must often sift through days, months, and sometimes years of testimony from expert witnesses, make highly technical factual determinations, and attempt to equate the nature of the defenses and remedies available to the various parties to those available at common law.

Nonetheless, while the historical test may have established a relatively bright line in determining which cases are triable by jury and which are not, its main problem is its failure to take into account either the changing role of the judge and jury or the increasing variety of causes of action available in our modern court system. In other words, the historical test has very little to say about which kinds of cases are best left to be determined by judges alone and which by jury. Indeed, the nation's legal history has been continually dotted by movements to eliminate, or at least limit, the kinds of cases which are referred to juries for decision. ${ }^{33}$ Many believe that some means other than jury trials should be devised to resolve the increasingly complex issues raised by modern litigation. ${ }^{34}$ In this view, juries are not sophisticated

same as that used in the courts of the states. Act of Sept. 29, 1789, § 2, 1 Stat. 93 (1789) (regulating the processes of the courts in the United States).

28. See Larry L. Teply \& Ralph U. Whitten, Civil Procedure 46-47 (1994) ("The principal purposes of the Federal Rules of Civil Procedure were similar to those of the [nineteenth century] codes: (1) merging law and equity, (2) simplifying and limiting pleading, (3) broadening claim and party joinder, (4) permitting amendments to be made more freely, and (5) liberalizing the rules governing variances between pleading and proof.").

29. FED. R. CIV. P. 2 ("There shall be one form of action to be known as a 'civil action.").

30. FED. R. CIV. P. 18(a), 19-25.

31. FED. R. CIV. P. 8(e)(1).

32. It is not all that clear, of course, that the distinction between common law and equity was ever easy to determine. The precise lines between the two have always been subject to dispute, at least at the margins.

33. See generally CARL T. BOGUS, WHY LAwSUITS ARE GOOD FOR AMERICA 88-94 (2001) (discussing claims that the jury is not competent to handle sophisticated products liability cases).

34. See Mark Curriden, Putting the Squezze on Juries, A.B.A. J., August 2000, at 52 (discussing 
enough to resolve difficult technical issues and thus must be discarded. Moreover, the continued erosion of distinctions between law and equity in the now-merged federal system makes it difficult to separate those cases that require the exercise of judicial "discretion" from those that merely require the "fact finding" abilities of a jury. Notwithstanding these concerns, however, courts continue to adhere to a historical approach to the civil jury trial clause.

For these and other reasons, the traditional view is not without its critics, and a number of commentators have put forth alternative readings of the clause. ${ }^{35}$ Among the most recent is that suggested by Akhil Amar in his book, The Bill of Rights. Professor Amar asserts that the Seventh Amendment was designed to "preserve" state-law rules governing the manner and mode of conducting jury trials. According to Amar, the "best reading" of the Seventh Amendment is this: "[ $\mathrm{I}] \mathrm{f}$ a state court entertaining a given commonlaw case would use a civil jury, a federal court hearing the same case . . must follow-must preserve-that state-law jury right." ${ }^{\text {"36 }}$ Although Amar admits that this interpretation is "not free from doubt," he contends that the Seventh Amendment was meant to establish a rule of "dynamic conformity" with respect to federal court jury procedure. The amendment was designed, he says, to provide a "floor and not a ceiling" which "shifts as state law shifts." ${ }^{38}$ Accordingly, whether a particular case is one that is tried to a jury depends on whether such a case is triable by jury in the courts of the state in which the federal court sits. In essence, federal court jury rules would be wholly dependent on those of the states.

While of some interest, Professor Amar's thesis is without any real support in the historical record. Although he claims that both federalist and antifederalist writers support the theory of dynamic conformity, ${ }^{39}$ the evidence points in exactly the opposite direction. For example, although a few federalists assured their audience that the civil jury rules "will be conformable to the local laws," required that result. Most simply believed that Congress would do so in an

attempts to limit jury verdicts).

35. An especially good critique of the historical test can be found in Stanton D. Krauss, The Original Understanding of the Seventh Amendment Right to Jury Trial, 33 U. RICH. L. REV. 407, 445-78 (1999).

36. AKHIL Reed AMAR, The Bill of Rights: CREATION AND RECONSTRUCTION 89 (1998).

37. Id.

38. Id.

39. See id. at 90 (detailing examples of how both groups of writers support his theory).

40. 2 Jonathan Elliot, The Debates, in the SEveral State Conventions, ON the ADOPTION OF THE FEDERAL CONSTITUTION, AS RECOMMENDED BY THE GENERAL CONVENTION AT PHILADELPHIA, IN 1787, at 112 (1827) [hereinafter ELLIOT'S DEBATES] (statement of Christopher Gore, Mass.); see also 4 ELLIOT'S DEBATES, supra, at 150 (statement of Gov. Samuel Johnston, N.C.) ("[T] rial will probably be, in each state, as it has been hitherto used in such state, or otherwise regulated as conveniently as possible....") (emphasis added). 
effort to allay the fears of an already concerned public. As for the antifederalists, almost all of their invective was directed at the fact that the Constitution lacked the rule contended for by Amar. ${ }^{41}$ Indeed, the only writer who discussed the subject of dynamic conformity at any length was Alexander Hamilton. However, Hamilton sought to show that none of the proposed amendments concerning civil juries was workable precisely because they would have resulted in a dynamic nonconformity in federal cases. In Hamilton's view, nonconformity in jury practice would produce "capricious" results and was "of itself sufficient to indispose every wellregulated judgment towards it." 42

Of far more importance, however, is the fact that no one in the first Congress appears to have read Madison's jury trial amendment to require conformity with state law. Furthermore, no one in either House-both of which made several alterations to the amendment-moved to alter the language so as to make the principle of dynamic conformity explicit. Finally, there is simply no evidence that any federal judge ever understood the Seventh Amendment to "preserve" state court jury trial rules. Indeed, as one commentator has noted, " $[\mathrm{N}]$ o federal official has ever-even implicitlyendorsed a dynamic conformity understanding of the Jury Trial Clause."

In fact, neither Story's historical test nor Amar's theory of dynamic nonconformity accurately reflect the true intent of the Seventh Amendment's drafters. On the contrary, the original understanding of the Seventh Amendment can only be found by examining the debate over the law-finding function of the civil jury. We now turn to that debate.

\section{THE "VERY ESSENCE OF LIBERTY"}

The jury was a well-established feature of the English judicial system long before the first American colonies were established. Although the earliest juries may have performed an administrative function, it is clear that by the twelth century, juries came to operate as a dispute resolution mechanism, supplanting the older forms of trial by ordeal or battle. ${ }^{44}$ The

41. See infra notes 217-20, 264-80 and accompanying text (describing antifederalist complaints about the Constitutio's failure to provide a guarantee for jury trials in civil cases).

42. The FEderalist No. 83 (Alexander Hamilton).

43. Krauss, supra note 35 , at 441 .

44. There is some dispute about the exact origins of the earliest juries. One view finds the origins of the jury in the Anglo-Saxon courts of the early Middle Ages and was associated with "the 'Anglo-Saxon' liberty that distinguished England from the Continental absolutist Romanlaw regimes." Mike MacNair, Vicinage and the Antecedents of the Jury, 17 LAw \& HIST. REV. 537, $539-40$ (1999). From a very early point in its history, this theory holds, the jury functioned as a judicial body composed of "laymen, who decided both factual and normative questions, or at least decided the form of proof (testimony, documents, compurgation, ordeal, or battle) that would settle the dispute." Id. An alternate view, however, holds that the jury had a testimonial, rather than a judicial, function, particularly in matters relating to the public fisc. Juries were, in other words, groups of "citizens summoned by royal command to testify about property 
rise of the jury system provided the Crown with an efficient means of resolving judicial disputes. At the same time, however, the widespread use of juries in both civil and criminal cases had "the unsalutory effect of teaching Englishmen to rule themselves." ${ }^{.45}$ Long years of service on both grand and petit juries gave the average Englishman an education in self-government, ${ }^{46}$ so that by the seventeenth century, men of modest property holdings were well-prepared to challenge the Crown, allowing Blackstone to argue that juries of the "middle rank" were "the best investigators of truth and the surest guardians of public justice."

There is perhaps a bit of exaggeration in Blackstone's words. The jury did not always stand as a bulwark against royal oppression. During the Tudor period, the criminal jury was a poor defense against royal judges intent on coercing a guilty verdict. In serious criminal cases, such as state trials for treason, juries were packed with members who were carefully selected or bribed to bring in the desired verdict. ${ }^{48}$ Judges also frequently intimidated juries with threats of fine or imprisonment if they dared to bring in a "false" verdict. ${ }^{49}$ As a result, juries could usually be relied upon to deliver verdicts in accordance with the Crown's wishes. Indeed, one Tudor-era jury later admitted to rendering a verdict "full sore against their conscience," but they feared "for safety of their goods and lives, which they were well assured to

arrangements, local customs, and taxable resources in each neighborhood of the realm." Stephan Landsman, The Civil Jury in America: Scemes from an Unappreciated History, 44 HASTINGS L.J $579,582-83$ (1993). According to this theory, the jury functioned as an informational tool, with jurors themselves giving testimony about the nature of their community. Using this testimony (one product of which was the Domesday Book of 1085-1086), the Crown was able to accurately assess property available for taxation as well as establish more efficient schemes for local governance. Id. at 583. The leading proponent of this theory was Heinrich Brunner in his book, DIE ENTSTEHUNG DER SCHURGERICHTE (1872).

45. Landsman, supra note 44 , at 588 .

46. Stephen K. Roberts, Juries and the Middling Sort: Recruitment and Performance at Devon Quarter Sessions, 1649-1670, in Twelve GOOD MEN AND TRUe 182 (J.S. Cockburn et al. eds., 1988); see also P.G. Lawson, Lawless Juries? The Composition and Behaviour of Hertfordshire Juries, 1573-1624, in TwELEVE GOOD MEN AND TRUE, supra, at 133 (describing jurors as having modest property holdings).

47. 3 WILlLAM BLACKSTONE, COMMENTARIES $* 683$.

48. W.R. CORNISH, THE JURY 128 (1968). Jury packing remained a problem even two centuries later. See generall' Jeremy Bentham, THE ElEmENTS of THE ART OF PACKING, AS Applied to Special JuRies (1821). See also Attorney General v. Horne (Tooke's Case), 20 St. Trials 651, 685-92 (K.B. 1777) (describing the Crown's attempt to pack a jury in a sedition case).

49. Judges accomplished this through the writ of attaint. See JAMES B. THAYER, A PRELIMINARY TREATISE ON EVIDENCE AT THE COMMON LAW 137-60 (1898). The use of the writ was a natural outgrowth of the fact that the early juries were supposed to come to court with some personal knowledge of the circumstances of the case. Id. A judge who suspected a jury of being "false" ordered other jurors empaneled to give another verdict. Id. If the second jury reached a different conclusion, the second verdict was substituted for the first, and the original jury was fined or imprisoned for violating their oaths. $I d$. 
lose, in case they had acquitted [the defendant]. ${ }^{, 50}$

There were a series of notable exceptions to the rule, however. In several celebrated political trials, juries stood against the Crown and acquitted defendants accused of treason. For example, in 1554, a jury refused to convict Sir Nicholas Throckmorton for his part in Wyatt's antiCatholic rebellion, although it was subsequently punished quite severely. ${ }^{51} \mathrm{~A}$ century later, another jury acquitted Sir John Lilburne, a leader of the Levellers, for his part in exciting opposition to Cromwell's regime. ${ }^{52}$ The verdicts in both cases were probably not based on reasonable doubt, for the evidence against both Throckmorton and Lilburne was quite strong. Rather, the jury's verdicts are best seen as "manifestations of tides of strong antiGovernment feeling among the populace of London at the time when the trials took place. ${ }^{53}$ Still, the conduct of the juries in both in these cases was notable precisely because it was so out of character. The verdicts resulted in the development of a belief in the jury as a defender of liberty although the jury had proved itself over time to be quite otherwise.

Another series of notable criminal cases in the years leading up to the Glorious Revolution solidified the jury's place in the popular imagination. As opposition to the Crown's attempt at prerogative rule increased during the latter part of the seventeenth century, Parliament paved the way for limiting the judges' power to punish juries with passage of a resolution declaring that "the late precedents in fining and imprisoning juries for giving in their verdict was illegal. . . ."54 The following year, the decision in Bushell's Case, in which the Court of Common Pleas prevented a judge from punishing a jury for failing to bring in a verdict in accordance with his instructions, assured the judges' defeat. ${ }^{55}$ A few years later in 1681, a grand

50. The King v. John Fisher, I St. Trials 395, 402 (Oy. \& Ter. 1535).

51. The King v. Nicholas Throckmorton, I St. Trials 869, 900-02 (Oy. \& Ter. 1554). An account of the rebellion and the aftermath can be found in D.M. LOADES, TWO TUDOR CONSPIRACIES 97 (1965).

52. The King v. John Lilburne, 4 St. Trials 1269, 1404-05 (Oy. \& Ter. 1649). A fuller account of Lilburne and the Levellers' activities can be found in G.E. AYLMER, THE LEVELLERS IN THE ENGLiSh Revolution 9-55 (1975); see also CHRISTOPHER Hill, A CENTURY OF REVOLUTION 135 (1961).

53. W.R. CORNISH, THE JURY 129 (1968).

54. JOHN Milward, THE DiaRy OF JOHN Milward SEPTEMber 17TH, 1666 TO MAY 8TH, 1668, 170 (Caroline Robbins ed., 1938).

55. The King v. Edward Bushell, 124 Eng. Rep. 1006, 1007 (C.P. 1670). The case arose after William Penn and William Mead were prosecuted for disturbing the peace by holding an unlawful assembly. Penn and Mead had preached a sermon to several hundred Quakers in the middle of a public street. The only question before the jury, therefore, was whether a meeting of this kind was a disturbance of the peace. The judge in the case ordered the jury to find that it was. The jury refused to do so, and granted an acquittal in spite of repeated threats from the judge. An enraged court then imprisoned the jurors for several months until most paid a fine. Four jurors refused to pay, however, and one of them finally obtained a writ of habeus corpus in the Court of Common Pleas. Chief Justice Vaughan discharged the writ and freed the jurors. In 
jury stood against the Crown in Shaftesbury's Case, refusing to indict the Earl of Shaftesbury on a charge of treason. ${ }^{56}$ The climax was reached in the Seven Bishop's Case, in which a jury refused to convict a group of Anglican bishops on a charge of seditious libel. ${ }^{57}$

The protection provided by the criminal jury was augmented by the willingness of civil juries to hold government officials accountable in trespass for wrongs committed against the citizenry. For example, in Entick $v$. Carrington ${ }^{58}$ and Wilkes $v$. Wood, ${ }^{59}$ civil juries brought in large damage awards against crown officers after they improperly used their position to intimidate critics of the government.

Together, these cases instilled in the public a belief in the jury as a defender of liberty. ${ }^{60}$ To a great extent, this confidence was misplaced,

so doing, Vaughan struck a blow for the independence of the jury. He asserted that jurors must be free to render a decision on the basis of their own independent knowledge of the relevant facts and witnesses without penalty. It would be "absurd," he said, to permit a judge to fine a jury for going against the evidence, when "the better and greater part of the Evidence may be wholly unknown to him." More importantly, Vaughan argued, the verdict in a criminal case is a general verdict, and thus one could never really know how the jurors had applied the law to the facts in their own minds. Bushell's Case was thus instrumental in freeing the jury from judicial coercion.

56. The King v. Anthony Earl of Shaftesbury, 8 St. Trials 759, 759 (K.B. 1681).

57. The Trial of the Seven Bishops, 12 St. Trials 183 (K.B. 1788). This case is said to be "the most memorable state trial recorded in the British annals." 4 THOMAS BABINGTON MACAULAY, THE HISTORY OF ENGLAND FROM THE ACCESSION OF JAMES II 195, 312 (Belford Clark ed., 1884). In April 1687, James II promulgated his now-famous Declaration of Indulgence, in which he announced an intent to guarantee free exercise of religion to Protestant Dissenters and Roman Catholics. James then proceeded to annul a series of statutes which impinged on the freedom to worship publicly or which required a religious test to hold public office. Although controversial, James II reissued the Declaration in April 1688, and ordered that it be read in all churches throughout the realm. The Archbishop of Canterbury, along with six other Anglican bishops, drafted a petition in which he urged the king to reconsider. The bishops argued that the king was not constitutionally empowered to unilaterally dispense with the statutes of the realm. The petition excited passions throughout England, and the bishops were eventually tried for publishing a seditious libel in the King's Bench. The jury brought in a verdict of not guilty, setting off a chaotic round of celebration among the populace that lasted through the night Seven Bishops, 12 St. Trials at 183. A popular account of the entire controversy is found in 4 MACAULAY, supra, at 312-56.

58. 95 Eng. Rep. 807 (K.B. 1765). John Entick authored a series of pamphlets that members of the government thought libelous. $I d$. at 810 . Lord Halifax, Secretary of State, issued a warrant authorizing Entick's arrest and the seizure of his papers. Entick sued the "messengers" of the Crown in trespass. Id. at 807 . The jury awarded Entick $£ 300$ in damages. Id. at 811 .

59. 98 Eng. Rep. 489 (K.B. 1763). John Wilkes was a member of Parliament who authored a series of pamphlets under the pseudonym "The North Briton." Id. at 493 . In Number 45 of the series, Wilkes sharply criticized a speech made by the king. Id. A warrant was issued for his arrest, and both Wilkes and his papers were seized. Wilkes sued and recovered a verdict against the messengers in the amount of $£ 1000$, a startling sum for the time. Id. at 493 . A separate suit against Lord Halifax resulted in a verdict of $£ 4000$. Id. The case is thought to be one of the first in which a jury was allowed to award punitive damages.

60. See generally SIR JOHN HAwES, THE ENGLISH-MAN's RIGHT (1630) (asserting the 
however. After all, most of these cases involved causes of great political moment, and public opinion influenced the juries' verdicts. Indeed, the verdicts themselves are best seen as judicial manifestations of widespread opposition to Crown policies, an opposition that was already being felt in other ways in English society. ${ }^{61}$ Nonetheless, by the end of the seventeenth century, the public came to regard the jury as one of the surest defenses against oppression by government officials. And, to the extent that the Crown attempted to use treason trials as a device for suppressing opposition, the jury was able to provide a good deal of protection. ${ }^{62}$

The essence of the jury's protective function was its ability to render in a "general verdict," that is, a verdict in which the jurors "take upon themselves to determine... the complicated question of fact and law" and "find a verdict absolutely either for the plaintiff or defendant. ${ }^{n 63}$ Thus, in a criminal case, law and fact were compounded into a single verdict of guilty or not guilty, with the result that the jury's verdict was essentially unreviewable. This meant that juries might ignore the law as stated by the judges and acquit based on their own collective sense of justice. ${ }^{64}$ In civil cases, on the other hand, juries were "free to apply whatever standard they wish [ed]," creating legal obligations on the basis of community norms. ${ }^{65}$ Immunizing the jury from sanctions for failing to return a desired verdict had the effect of

superiority of juries over all other methods of trial); WILLIAM WALWIN, JURIES JUSTIFIED (1651) (same); Thomas Williams, The Excelling and PRAEHEMinence of tHe LAW OF ENGLAND 1819 (1680) (asserting that trial by jury "is grounded upon so many circumstances of Equity and Indifference for the avoiding all corruption and sinister affection, that greater caution cannot be devised by Man").

61. In the Earl of Shaftesbury's Case, in particular, Macaulay relates that the Crown's prosecution foundered because the facts allegedly giving rise to the crime were committed in the City of London. 1 MacaulaY, supra note 57, at 244. This meant that the Crown had no ability to pack the grand jury because the Sheriff of London was chosen by the citizenry, who were all "zealous Whigs." Id. at 244-45. The grand jury's refusal to indict so enraged the Crown that it initiated an action in the King's Bench to have the city's charter declared forfeit to the Crown. Id. at 248.

62. That the jury was somewhat successful in this regard can be witnessed by the fact that by the eighteenth century, the Crown had all but abandoned treason trials as a means of suppressing opposition. Sedition trials soon became the weapon of choice. Rather than risk an acquittal on a treason charge, royal officials resorted to using prosecutions for sedition as a tool for punishing critics of the government. Doing so meant getting around a jury, but the judges were up to the task. Lacking power to punish juries who failed to bring in the desired verdict in treason cases, judges soon took upon themselves the power to decide the essential question in sedition cases: "Did the words or publication amount to sedition or not?" The jury was left to decide only the fact of publication or utterance. The decision as to whether the words were seditious remained a "question of law" for the judges. By the end of the eighteenth century, this device, too, came under fire from many quarters. See, e.g., Rex. v. Shipley (The Dean of St. Asaph's Case), 21 St. Trials 847, 1034-35 (K.B. 1783) (utilizing this reasoning).

63. 3 WILLIAM BLACKSTONE, COMMENTARIES *378.

64. See, e.g., Rex v. Lilburne, 4 St. Trials 1270, 1379-82 (Oy. \& Ter. 1649) (convicting Lilburne contrary to the stated law).

65. BRUCE H. MANN, NEIGHBORS AND STRANGERS 71 (1987). 
making it a bulwark against arbitrary government. The jury became "irresponsible" in that it was free to render a verdict guided only by its collective conscience. ${ }^{66}$

\section{THE JURY IN THE COLONIES}

In England, the struggle over the jury's power to return a general verdict was essentially political in nature. The ability to free a man accused of some offense against the Crown, or to assess damages against the king's ministers for violating the rights of a subject, was the primary means by which the common people were able to combat royal oppression. In the colonies, on the other hand, the struggle over the right to trial by jury took on a new dimension. Although the jury remained an important defense against royal abuse, the American colonists soon looked to the jury as an important weapon in the fight for economic self-determination.

Every American colony provided for a right to jury trial in the supreme or superior court. ${ }^{67}$ Yet one of the most intriguing aspects of the early American jury is that it possessed the power not only to find fact, but to determine the law as well. In fact, the latter part of the eighteenth century is notable for a remarkable consensus on the power of the jury to say not only "what happened" in a particular case, but what law might be applied. ${ }^{68}$ The power to bring in a general verdict effectively made juries "the chief assessors of legal claims and the primary enforcers of legal rights for their communities." ${ }^{69}$ The jury brought a shared consensus about right and wrong that was not always in accord with traditional common-law principles. Its power over fact and law meant that it was instrumental in maintaining the moral and economic structure of the community. Juries were thought to be desirable precisely because of the expectation that they would apply "the same standards in their deliberations that the litigants themselves would apply in similar cases involving others, which is to say standards shaped by a

66. Theodore F.T. PluCKNETt, A CONCISE History OF THE COMMON LAW 137 (5th ed. 1956).

67. James I's 1606 charter to the Virginia colony may be read as incorporating a right to trial by jury. By 1624, it appears that jury trials were readily available in Virginia for both civil and criminal actions. The Massachusetts Body of Liberties guaranteed the same right in 1641 . MASSACHUSETTS BODY OF LIBERTIES $\$ 29$ (1641), reprinted in 5 SOURCES AND DOCUMENTS OF THE UNITED STATES CONSTITUTION 46, 51 (Swindler ed., 1975). Jury trials came to the middle colonies via the Duke of York's Laws, which provided for panels of six or seven in most cases, and a majority vote was sufficient to bring in a verdict. Where a crime was punishable by death, the jury was to be composed of twelve and the verdict was to be unanimous. DUKE OF YORK's LAwS (Sept. 22, 1676), in CharTer of William PENN AND LAWS OF THE Province OF PENNSYlVANIA 3, 34 (John Blair Linn ed., 1879) [hereinafter CHARTER AND LAws of PENnsylvania]. William Penn's Laws Agreed Upon in England provided that all trials in Pennsylvania should be by a jury of twelve. Id. at $100,117,154$.

68. See supra note 10 (providing a reference to Matthew Harrington's research on the lawfinding function of a jury).

69. Landsman, supra note 44 , at 592. 
template of common beliefs and expectations as to how neighbors should treat one another." ${ }^{, 70}$ Jurors thus determined legal issues against the background of community norms and performed "a mediating function between law and society." 11

The jury's law-finding function involved more than the power to "nullify" unpopular laws, although that was certainly a function of the power. Rather, the jury's law-finding function was far more comprehensive and permitted the jury to bring in a verdict "in the teeth of both law and facts." This meant that both civil and criminal juries might take upon themselves the power to bring in a verdict contrary to the judges' instructions. The fact that judicial devices for setting aside the verdict were quite limited reinforced the jury's relative supremacy on questions of law. As a result, by the latter part of the eighteenth century, the jury had assumed a paramount position in the colonial judicial structure, with the result that the jury's lawfinding function was regarded as an essential protection against government abuse. In a series of well-publicized cases before the Revolution, the jury was hailed as a fundamental check on the abuses of the Crown. The most celebrated of these cases was the sedition trial of John Peter Zenger in $1734 .^{73}$ The refusal of colonial juries to convict Zenger and other defendants

70. MANN, supra note 65 , at 71 .

71. Id. at 75.

72. Horning v. District of Columbia, 254 U.S. 135, 138 (1920).

73. For a brief discussion of the Zenger case, see A BRIEF NARRATIVE ON THE CASE AND TRIAL OF JOHN PETER ZENGER, PRINTER OF THE NEW YORK WEEKLY JOURNAL (S.N. Katz ed., 1963). While the Zenger trial is more frequently associated with the principle of freedom of the press, it is perhaps more significant for the impact on the colonial belief in the jury's lawfinding function. Zenger accused New York's governor, William Cosby, of corruption and misfeasance in office. After three separate grand juries refused to indict, New York's attorney general commenced a prosecution for libel by information. Andrew Hamilton took up Zenger's defense. During the trial, Hamilton sought to introduce evidence that Zenger's article was true, and thus not actionable under the law. The court rejected Hamilton's proffered defense. Chief Justice De Lancey insisted that "the jury may find that Zenger printed and published those papers, and leave it to the Court to judge whether they are libelous; you know this is very common; it is in the nature of a special verdict, where the jury leave the matter of law to the Court." Id. at 78. Hamilton, of course, opposed to the idea of leaving the legal question to the judge. Instead, he insisted upon the jury's right to bring in a general verdict:

I know... the jury may do so; but I do likewise know they may do otherwise. I know they have the right beyond all dispute to determine both the law and the fact, and where they do not doubt of the law, they ought to do so.... [L] eaving it to the judgment of the Court whether the words are libelous or not in effect renders juries useless.

Id. In the event, the jury was allowed to bring in a general verdict, and Zenger was acquitted. Larry D. Eldridge, Before Zenger: Truth and Seditious Speech in Colonial America, 1607-1700, 39 AM. J. LEGAL HIST. 337, 357 (1995). Zenger's trial is credited with virtually ending common-law sedition prosecutions in the colonies. Id. After Zenger, there appear to have been less than onehalf dozen sedition trials and only two convictions. Grand juries were, it seems, reluctant to indict, while petit juries refused to convict. Albert W. Alschuler \& Andrew G. Deiss, A Brief History of the Criminal Jury in the United States, 61 U. CHI. L. REV. 867, 873-74 (1994); see also 
charged with libeling government officials enabled them to serve as a singularly potent defense against arbitrary rule, much like their English predecessors.

The jury also served as a means by which the colonists could restrict the operation of the various "navigation acts," a series of statutes designed to secure compliance with England's intricate system of trade barriers and tariffs. ${ }^{74}$ The purpose of the acts was to make England a trade entrepot for the colonies as well as to aid in the growth and maintenance of English shipping. ${ }^{75}$ The acts were designed to eliminate foreign shipping in the colonies, control the importation of certain enumerated commodities, and strengthen England's hold over the colonial market. In general, the acts restricted trade between England and the colonies to goods carried in English bottoms, while the export of certain commodities, such as tobacco, sugar, cotton, indigo, and ginger was restricted to British destinations. The navigation acts also laid heavy tariffs on certain commodities and imposed severe fines on violators. Many colonists regarded the acts as a serious drag on the colonial economy and used various means to circumvent them. As a result, by the early part of the eighteenth century, the most important problem facing the imperial government was devising a means by which the colonists could be forced to trade within the imperial pattern.

Bringing violators to justice turned out to be an especially difficult problem. In England, violations of the navigation acts were tried in the Exchequer Court using juries. ${ }^{76}$ In the colonies, however, it quickly became apparent that common-law juries could frustrate the enforcement of the

LEONARD W. LeVY, EMERgenCE OF A Frfe PRESs 17 (1985) (indicating that the Zenger case was basically the last of its kind); Harold L. Nelson, Seditious Libel in Colonial America, 3 AM. J. LEG. HIST. 160, 170 (1959) (arguing that trials for seditious libel ended following the Zenger trial).

74. The principal navigation acts were:

12 Car. 2, c. 18, 5 Stat. 246 (1660) (encouraging and increasing of shipping and navigation).

14 Car 2, c. 11, 5 Stat. 393 (1662) (preventing frauds, and regulating abuses in his Majesty's customs).

15 Car. 2, c. 7, 5 Stat. 449 (1663) (encouraging trade).

25 Car. 2, c. 7, 5 Stat. 792 (1672) (encouraging Greenland and Eastland trades and securing the plantation-trade).

7 \& 8 Will 3, c. 22, 7 Stat. 103 (1696) (preventing frauds, and regulating abuses in the plantation trade).

A fuller discussion of the purpose and operation of the navigation acts can be found in Matthew P. Harrington, The Legacy of the Colonial Vice-Admiralty Courts (Part I), 26 J. MAR. L. \& CoM. 581, 591-95 (1996) [hereinafter Harrington, Vice-Admiralty Part $\prod$ ].

75. See, e.g., LAWrence A. HARPER, THE ENGliSH Navigation LAws 19-33 (1933) (discussing the purposes of the navigation acts).

76. Attorney General v. Brown, 145 Eng. Rep. 1018, 1018 (Ex. 1796) (resulting in the forfeiture of a vessel in a jury trial); Mitchell qui tam v. Torup, 145 Eng. Rep. 764, 764 (Ex. 1766) (same); Scott qui tam v. A'Chez, 145 Eng. Rep. 702, 702 (Ex. 1743) (same). 
revenue laws by simply refusing to convict those accused. ${ }^{77}$ Juries exercised this power without reservation. Indeed, one Massachusetts governor complained that "[a] Custom house officer has no chance with a jury," despaired that "a trial by jury here is only trying one illicit trader by his fellows, or at least by his well-wishers." ${ }^{79}$ The situation became so bad that Maryland's Governor Francis Nicholson sought advice on how a jury might be punished for bringing in an incorrect verdict. He feared that without such a weapon at the government's disposal, "the King will not have justice done to him about illegal trade. ${ }^{~} 80$ Charles Carroll offered his opinion in a

77. Various colonial officials complained about the partiality of colonial juries. As early as 1695, Edward Randolph, Surveyor General of the Gustoms, wrote Maryland Governor Francis Nicholson of his desire to go to England to obtain personal instructions from the Lords of Trade as how best to suppress the illegal trade taking place between Pennsylvania, Maryland, and Virginia. He was particularly discouraged by the inability of the Crown to get convictions in the common-law courts:

I find that by the partiality of Juryes \& others I can obtain no cause for his [Majesty] upon the most apparent Evidences in the Courts of Record holden in these Severall plantacons, ... and as yet no Remedy appeares for regulating such apparent breaches of the Severall Acts of Trade ....

Letter from Edward Randolph to Governor Francis Nicholson (May 20, 1695), in 20 ARCHIVES OF MARYLAND 236 (May 20, 1795). A later letter to the Board of Trade from Governor Nicholson echoed Randolph's complaints noting that "[ $t]$ he country juries will hardly ever find against [illicit traders]." Letter from Sir Thomas Lawrence to the Board of Trade, in CALENDAR OF STATE PAPERS, COlONIAL SERIES AMERICA AND WEST INDIES, JANUARY, 1693 to 14 MAY, 1696, at No. 1916 (1903) [hereinafter CSP: COL.]. Whether Randolph's complaints about juries in trade cases were justified remains in some doubt, however. Between 1692 and 1695, Maryland juries acquitted in five of six cases brought for violation of the navigation acts and tried in the common-law courts. DAVID R. OWEN \& MichaEL C. TOLLEY, THE COURTS OF ADMIRALTY IN AMERICA: THE MARYLAND EXPERIENCE, 1634-1776, at 274-289 (1995). Some have argued, however, that this record may be simply the result of Randolph's lack of preparation for the cases. HARPER, supra note 75, at 195 (noting that "we should disregard the cases in which [Randolph] was involved because of his tendency to fail to produce the evidence required to sustain a verdict"); see also Letter from Lionel Copley to the Board of Trade (Dec. 21, 1692), in CSP: COL., supra, at No. 371 (criticizing Randolph's "rude and insolent behaviour" in court).

Others echoed Randolph's complaints, however. As late as 1764, Massachusetts's Governor Bernard advised the Board of Trade that

the reason for putting [trade] causes into a course of trial without jury, undoubtedly arose from an apprehension that the juries in these causes were not to be trusted. The force of this reason may have abated, but I cannot think that it is wholly destroyed; no candid man, I believe, will take upon him to declare, that an American jury is impartial and indifferent enough, to determine equally upon frauds of trade.

Letter from Governor Bernard to the Board of Trade (1764), reprinted in WINFRED TREXLER ROOT, THE RELATIONS OF PENNSYLVANIA WITH THE BRTISH GOVERNMENT, 1696-1765, at 126 n.136 (1912).

78. Erving v. Cradock, 1 Quincy 553, 556-57 n.4 (1761).

79. Letter from Governor Francis Bernard to the Lords of Trade (Aug. 21, 1761), reprinted in Erving v. Cradock, 1 Qunicy at 556-57 n.4.

80. Letter from Governor Francis Nicholson to the Lords of Trade (Mar. 18, 1696), in 
letter to Nicholson, suggesting that verdicts adverse to the Crown might be overcome through greater use of the "appeal."

[I]n this Country, there ought to be greater latitude allowed in assigning Errors, and the merits of the Cause to be more inquired into by the Judges before whom an Appeal or Writ of Error is brought, than in England; Because some of our Judges and some of our Juryes ... do oftentimes Judge according to the Affection or disaffection they have for the person plaintiff or Defendant, and not according to the Merit of the Cause or the Law that Arises on the pleadings thereof. ${ }^{81}$

Carroll believed that the problem of biased juries might be solved by allowing appellate courts to adopt the appeal. This mode of proceeding had its origins in the ecclesiastical courts and would have allowed the reviewing court to rehear both the law and the fact, thus reversing a verdict whenever the judges believed the jury was mistaken as to either. ${ }^{82}$

The difficulties inherent in using common-law courts to try trade cases eventually forced the Crown to look elsewhere for a solution. It found one in the creation of a system of vice-admiralty courts for the colonies. ${ }^{83}$ While admiralty courts had a long history in England, their jurisdiction had generally been limited to resolving traditional commercial maritime cases, such as suits for seamen's wages as well as collision and cargo damage. Using admiralty courts to try what would have been common-law jury cases in England was controversial, because admiralty courts did not use juries. Indeed, they were regarded as a foreign invention and roundly condemned for their tendency to subvert the rights of the colonists. ${ }^{84}$ Nonetheless, shortly after the arrival of the first vice-admiralty judges in the colonies, local customs officers began to bypass the common-law courts in favor of the viceadmiralty courts in order to avoid trying trade cases to a jury. The practice

CSP: COL., supra note 77, at No. 2303. Nicholson referred, of course, to the writ of attaint, the traditional means of punishing juries for bringing in a "false" verdict. The rise of the writ of attaint is described at length in 1 WILLIAM HOLDSWORTH, A HISTORY OF ENGLISH LAW 337-42 (1926).

81. Letter from Charles Carroll to the Governor and Council (May 21, 1696), in 20 ARCHIVES OF MARYLAND 439.

82. The appeal had a long history in English law in both the maritime and equity courts as well. Far from being a mere procedural device, the appeal had its origins in "the aspiration to do full justice between the parties." Mary Sarah Bilder, The Origin of the Appeal in America, 48 HASTINGS L.J. 913, 931 (1997) (quoting ROBERT E. RODES, JR., ECCLESIASTICAL ADMINISTRATION IN MEDiEVAL ENGLAND: THE ANGLO SAXONS TO THE REFORMATION 142 (1977)).

83. 7 \& 8 Will. III, c. 22, 7 Stat. 103 (1696) (preventing fraud and regulating plantation trade). For a more thorough discussion of the creation and workings of the colonial viceadmiralty courts, see Matthew P. Harrington, The Legacy of the Colonial Vice-Admiralty Courts (Part II), 27 J. MAR. L. \& COM. 323, 332 (1996) [hereinafter Harrington, Vice-Admiralty Part II].

84. Harrington, Vice-Admiralty Part II, supra note 83, at 332-37 (describing controversy over use of admiralty courts to try violations of trade laws). 
infuriated the colonists, who reacted by obstructing the work of the admiralty courts in trade cases. ${ }^{85}$ As time went on, the colonists repeatedly denounced the extensive jurisdiction of the courts of admiralty in America. Among the courts' most vociferous critics was John Adams, who frequently appeared before the Massachusetts vice-admiralty court, and who decried "the Brand of Infamy, Degradation and Disgrace fixed upon every American" by the vice-admiralty's power to try trade cases without a jury. ${ }^{86}$

That colonial vice-admiralty courts had jurisdiction over breaches of the navigation acts was a constant source of irritation to American traders. However, Parliament continued to fan the flames throughout the 1760s. In the Sugar Act, ${ }^{87}$ Parliament not only expanded the category of cases triable in the vice-admiralty, it also altered the burden of proof in trade cases. Merchants whose vessels were seized by customs officers now had the burden of proving that they were not involved in smuggling. Moreover, if a merchant was successful in carrying that burden, the Sugar Act allowed the vice-admiralty judge to "certify" that probable cause existed for the seizure, thus immunizing the customs house officer from damages for wrongful arrest. ${ }^{88}$ No doubt the most onerous provision of the Sugar Act, however, involved the creation of a new vice-admiralty court in Halifax, Nova Scotia. This new court had jurisdiction over all cases arising from violations of the trade or revenue acts, regardless of where the offense took place. This meant that customs or naval officers could carry a seized vessel to Halifax, even though the seizure occurred in a place as distant as Georgia or South Carolina. As a result, many merchants faced the prospect of losing their property because they could not afford the costs of defending it in such a remote place. ${ }^{89}$ Rhode Island's General Assembly objected to these new provisions, declaring that " $[t]$ he extensive powers given ... to the courts of vice admiralty, in America, have a tendency, in a great measure, to deprive the colonists of that darling privilege, trials by juries, the unalienable birthright of every Englishman; and subjects the inhabitants here to other

85. Opposition to the creation of the vice-admiralty courts was intense, and many colonial officials took steps to obstruct the courts' work. In Rhode Island, the governor refused to administer the oath of office to the new admiralty judge, thus rendering his commission a dead letter. Connecticut's governor refused to recognize a judge's commission on the grounds that it was an infringement of the colony's charter. South Carolina's admiralty judge complained bitterly about the fact that the government in that colony obstructed his work. In the Bahamas, on the other hand, the governor openly denounced the admiralty judge's commission and the judge was forced to flee for his life. For their part, Pennsylvania's colonial officials repeatedly conspired to frustrate the work of the court whenever possible. RooT, supra note 77, at 97-103.

86. John Adams, Draft of Argument in Sewell v. Hancock (Oct. 1768-Mar. 1769), reprinted in 2 The LeGal PAPERS OF JOHN ADAMS 194, 200 (L. Kinvin Wroth \& Hiller B. Zobel eds., 1965).

87. 4 Geo. 3 , c. 15 (1764).

88. Id.

89. CARL UBBELOHDE, THE VICE-ADMIRALTY COURTS AND THE AMERICAN REVOLUTION 5054, 60-63 (1960) (detailing merchants' complaints about jurisdiction of the Halifax court). 
great hardships and intolerable expenses" to the point that "we are unhappily distinguished from our fellow subjects in Britain."

The Stamp Act ${ }^{91}$ added to the controversy by extending the jurisdiction of the vice-admiralty courts. The Act, which had little to do with maritime commerce, required that revenue stamps be affixed to all sorts of legal papers. In addition, revenue officials had the choice of trying violations of the Act in either the common-law or vice-admiralty courts. The Stamp Act was thus a completely new extension of the traditional admiralty jurisdiction of the vice-admiralty courts, because it essentially gave vice-admiralty judges power to hear cases involving violations of inland revenue laws, in addition to that existing under their already-novel jurisdiction in trade cases. ${ }^{92}$ The colonists were incensed. The Stamp Act Congress of 1765 reacted by declaring that "trial by jury is the inherent and invaluable right of every British subject in these colonies," and that "the said act, and several other acts, by extending the jurisdiction of the courts of admiralty beyond its ancient limits, have a manifest tendency to subvert the rights and liberties of the colonists." 94

The denial of jury trials in this fashion became a major source of friction between the colonists and the English government in the years leading to the Revolution. Merchants and traders in several colonies attempted to shut down the vice-admiralty, or at least make it impossible for customs officers to bring cases against violators of the navigation acts. They also enlisted the aid of common-law judges and juries. Through writs of prohibition issuing out of common-law courts, merchants in Rhode Island were able to bring the work of the vice admiralty to a halt for over two years. ${ }^{9 \overline{5}}$ Envious of Rhode Island's success, Massachusetts's merchant community decided to take similar action. In August 1761, Governor Bernard advised the Board of Trade of a plot by several merchants to bring suit against customs officers for trespass in the common-law courts in an effort to harass and intimidate royal officials into giving up enforcement of the navigation acts. Bernard warned the Board that "these actions have an immediate tendency to destroy the Court of Admiralty and with it the

90. Petition of the Governor and Company of Rhode Island to the King (Nov. 29, 1764), in 6 Records of THE COLONY OF RHOdE IsLaNd AND Providence PLANTATIONS IN NEW ENGLAND 414, 415 (John Russell Bartlett ed., 1861) (1764); see also Stephen Hopkins, The Rights of the Colonies Examined, reprinted in 6 RECORDS OF THE COLONY OF RHODE ISLAND AND Providence Plantations in New England, supra, at 416, 422 (complaining of the "unbounded encouragement and protection" given to informers by the Sugar Act).

91. 5 Geo. 3 , c. 12 (1765).

92. Harrington, Vice-Admiralty Part II, supra note 83, at 332-37.

93. Resolutions of the Stamp Act Congress, art. VII (1765).

94. Id. at art. VIII.

95. Memorial of John Andrews, Judge of the Court of Vice Admiralty for Rhode Island (June 13, 1763), in 6 RECORDS OF THE COLONY OF RHODE ISLAND AND PROVIDENCE PLANTATIONS IN NEW ENGLAND, supra note 90, at 371. 
Custom house, which cannot subsist without that Court."96

By the early 1770s the controversy had come to a head. In 1774, the First Continental Congress declared that "the respective colonies are entitled to the common law of England, and more especially to the great and inestimable privilege of being tried by their peers of the vicinage, according to the course of that law. ${ }^{.97}$ In 1775, the Second Continental Congress's Declaration of the Causes and Necessity of Taking up Arms asserted that Parliament had deprived the colonists "of the accustomed and inestimable privilege of trial by jury, in cases affecting both life and property." ${ }^{\text {"98 }}$ Prominent in the "[h]istory of repeated injuries and usurpations" recited by the Declaration of Independence was that George III had "combined with others" to deprive the colonists "in many cases of the Benefits of trial by Jury" and transported them "beyond Seas to be tried for pretended offences." ${ }^{, 99}$

In the end, the conflict over the law-finding function of the colonial jury was more than merely political. It was, in fact, part and parcel of the ongoing struggle for economic self-government being waged on a variety of levels in every colony. Thus, the jury's power to declare both law and fact had an economic dimension that is often overlooked. While efforts to limit the jury's law-finding function in criminal cases went a long way toward solidifying political opposition to the Crown, the ability to find both law and fact in civil cases was equally important to the colonists' struggle for economic independence. Consequently, to the extent that the Crown was successful in restricting the jury, it tightened its hold on the colonial economy. As might have been expected, however, success in this endeavor merely added an economic component to the ongoing ideological struggle between the Crown and the colonies.

By the time of the Revolution, therefore, the jury had become a symbol of the colonists' drive for self-government. Its law-finding function made it ground zero in the battle between the king's ministers and colonial leaders. Like their English forebears, the colonists looked upon the jury as an important weapon in combating royal oppression. In criminal cases, the colonists were able to use the jury as a shield against royal abuse. In civil cases, on the other hand, the jury functioned as a sword by which the colonists struck back at attempts to limit their economic development. In the end, although they were unable to combat unpopular laws in Parliament, Americans used the jury to nullify legislation. "Victimless"

96. Letter from Governor Francis Bernard to the Board of Trade (Aug. 6, 1761), reprinted in Erving v. Craddock, 1 Quincy 553, 555 n. (Mass. 1761).

97. Statement of Violations of Rights (Oct. 14, 1774), in 1 JOURNALS OF THE CONTINENTAL CONGRESS 1774-1789, at 69 (Worthington Chauncey Ford ed., 1904) [hereinafter JCC].

98. Declaration of the Causes and Necessity of Taking up Arms (July 6, 1775), in 2 JCC, supra note 97 , at 140 .

99. THE DECLARATION OF INDEPENDENCE para.19 (U.S. 1776). 
crimes, like sedition and smuggling, were essentially unenforceable because they lacked public support. In the case of the trade laws, this meant that the entire system of customs and revenue verged on collapse. The Crown was forced to devise means to bypass the common-law courts in an attempt to avoid having to prosecute such cases before juries. The result was an inexorable downward spiral: unpopular legislation went unenforced by juries, which meant that more unpopular legislation was enacted to remedy the problems created by the first. The colonists' grievances were thus compounded, until a break with the mother country was inevitable. ${ }^{100}$

\section{JURIES IN THE NEW NATION}

In the 1770s, the jury emerged as a symbol of the struggle for independence. Its reputation as a defender of liberty meant that it was destined to occupy a prominent place in the creation of the new state governments. Indeed, the attachment to the jury was such that every state constitution guaranteed the right to trial by jury in both civil and criminal cases. ${ }^{101}$ Nonetheless, the esteem in which the jury was held appeared to wane somewhat during the Confederation period, at least as far as men of property or substance were concerned. The jury's power to find law as well as fact seemed less attractive to those who also worried about the power increasingly held by populist elements in state governments. Political elites came to regard the jury's law-finding function as an undesirable aspect of the judicial system, and thus began to seek some means by which juries might be restrained-at least in certain civil cases. There was, to be sure, still a strong ideological attachment to the jury's law-finding power in criminal cases, and no self-respecting patriot would have suggested otherwise. Yet, in a rather ironic twist, an increasingly powerful segment of the community came to view the civil jury's law-finding function as an obstacle to the new nation's economic and commercial development. Many erstwhile Revolutionaries worried about the impact arbitrary decisions of civil juries would have on America's relations with foreign powers, particularly in prize and debt cases. ${ }^{102}$

100. To be sure, the causes of the American Revolution were manifold. In the larger scheme of things, the complaints about the jury were merely one part of an extensive catalogue of grievances over revenue and trade laws, taxation, representation, and royal abuse.

101. The right to jury trial in civil cases was continued in all thirteen of the new states by express provision in the state constitution or by statute. See GA. CONST., art. 61 (1777); MD. CONST., art. 3 (1776); MASS. CONST., art. 15 (1780); N.H. CONST., art. 20 (1784); N.J. CONST., art. 22 (1776); N.Y. CONST., art. 41 (1777); PA. CONST., art. 14 (1776); VA. CONST., sec. 11 (1776); N.C. CONST., art. 9 (1776); S.C. CONST., art. 41 (1778) (each of these state constitutions expressly provides for the right to trial by jury).

102. Infra text accompanying notes 148-49. 


\section{A. THE DEBT CASES}

The problem of debt loomed large during the nation's early years, causing particularly difficult problems for the courts of the Confederation. The source of the difficulty lay in the revolution in credit relations occurring between British merchants and Virginia planters in the middle part of the eighteenth century. Hard currency was scarce in the rural economy, so large farmers financed the harvest on credit, using future crops as collateral on loans for the building materials and goods they needed at that time. Two groups of British merchants were primarily involved in this trade. Located mainly in London and Bristol, English merchants extended credit to American farmers who shipped grown crops to England on consignment. When the crops were sold, the merchants deducted the sums necessary to satisfy the planters' debt and returned the surplus (if any) to Virginia. ${ }^{103}$ In this way, Virginia farmers were able to obtain large extensions of credit backed by the crops in their fields. Farmers in other states soon followed the Virginians into debt, so that by the time of the Revolution, American indebtedness to British merchants amounted to approximately $£ 4,930,656$. The five southern states accounted for eighty-three percent of the total. Virginia farmers alone were liable for forty-five percent. ${ }^{104}$

The outbreak of war with the American colonies was a catastrophe for British merchants. Colonial debtors naturally refused to pay their debts, leaving their creditors without any recourse. Suing for payment was an impossibility because the courts in many colonies closed when hostilities began. Even where the courts remained open, British creditors were effectively prevented from maintaining a suit for debt because the laws of both England and the various states prohibited citizens of an enemy from suing in the courts of their adversaries. State legislatures added to the

103. See Wythe Holt, "To Establish Justice": Politics, the Judiciary Act of 1789, and the Invention of the Federal Courts, 1989 DUKE L.J. 1421, 1430-35; see also Emory G. Evans, Planter Indebtedness and the Coming of the Revolution in Virginia, 19 WM. \& MARY Q. (3d Ser.) 511 (1962); Jacob M. Price, The Rise of Glasgow in the Chesapeake Tobacco Trade, 1707-1775, 11 WM. \& MARY Q. (3d Ser.) 179 (1954).

104. Samuel Flagg Bemis, Jay's TREATY: A Study in Commerce and Diplomacy 140 (162). Bemis provides the following account of Colonial Debt to the British:

\begin{tabular}{lrlr} 
& \multicolumn{3}{c}{ BRITISH DEBT IN 1790 } \\
STATE & AMOUNT & STATE & AMOUNT \\
Virginia & $2,305,408$ & Pennsylvania & 229,452 \\
South Carolina & 687,953 & New York & 175,095 \\
Maryland & 517,455 & Rhode Island & 49,208 \\
North Carolina & 379,344 & Connecticut & $\mathbf{2 8 , 6 5 3}$ \\
Massachusetts & 287,982 & New Hampshire & $\mathbf{2 1 , 7 9 5}$ \\
Georgia & 247,781 & New Jersey & 524 \\
& & TOTAL: & $£ 4,930,656$
\end{tabular}


creditors' difficulties by passing a series of laws confiscating British property. Confiscation not only prevented the enemy from using its wealth to prosecute the war, it also provided a source of revenue to state governments desperately in need of money to pay wartime expenses. Most of these statutes applied only to real or personal property, although some confiscated debts as well. ${ }^{105}$ States also passed statutes specifically designed to prevent British creditors from recovering debts. Maryland and Virginia allowed debtors to discharge their debts by making payments into the state treasuries using paper money. ${ }^{106}$ The rapid depreciation of colonial currency made tender in paper money an attractive option because it allowed debtors to pay a vastly depreciated amount to satisfy their debts. ${ }^{107}$ Maryland, Virginia, North Carolina, and New Hampshire closed their courts to British creditors. $^{108}$ Pennsylvania and New York suspended executions on judgements for debt. ${ }^{109} \mathrm{New}$ York also suspended the right of British creditors to have interest accrued during the war. ${ }^{110}$

The subject of debt thus became one of the primary points of contention during the peace negotiations in 1781-1783. The British cabinet twice rejected drafts of a peace treaty it thought contained inadequate protections for the rights of British merchants. ${ }^{111}$ For their part, the American commissioners negotiating the treaty were divided on the question. Benjamin Franklin was wary of the Confederation's power to force

105. Holt, supra note 103 , at 1437-38.

106. Act of Oct. 1780, ch. 5, $\S 12,1780 \mathrm{Md}$. Laws 12; Act of Oct. 20, 1777, 1777 Va. Laws. ch. 17 (permitting the sequestration of British property, enabling those indebted to British subjects to pay off debts, and directing the proceedings in suits where such subjects are parties).

107. The Virginia state treasury received $£ 275,554$ worth of paper money, with a sterling value of $£ 15,044$. Maryland received $£ 144,474$ in payment of debts amounting to $£ 86,744$ sterling. Virginia debtors thus obtained an $82 \%$ depreciation of their debts. Maryland's creditors did better, receiving $60 \%$ of the amount due. RICHARD B. MORRIS, THE FORGINC OF THE UNION, 1781-1789, at 197 (1987). In 1787, Rhode Island's Washington County Court heard more than twenty bills in equity for redemption of mortgages at its April term. The paper for the redemptions were brought into court "by the sackful." FRANK GREENE BATES, RHODE ISLAND AND THE FORMATION OF THE UNION 143-44 (The Faculty of Political Sci. of Columbia Univ. ed., AMS Press, Inc. 1967) (1898).

108. Act of Apr. 25, 1782, ch. 55, 1782 Md. Laws 55 (preventing suits on certain debts for a limited time); Act of Nov. 15, 1777, ch. II, § 101, 177 N.C. Laws 226 (1777) (establishing courts of law and regulating the proceedings therein); Act of July 12, 1782, ch. 22, 10 Va. Stat. 471, 472 (1782) (directing the mode of adjusting and settling the payment of certain debts and contracts); Act of May 6, 1782, ch. 44, 11 Va. Stat. 75 (1782) (repealing so much of a former act as suspended the issuing of executions upon certain judgments until December 1783).

109. Act of July 12, 1782, ch. 1, 1782 N.Y. Laws 499 (relating to debts due to persons within the enemies lines); Act of Mar. 12, 1783, ch. 53, § 3, 1783 Pa. Laws 138 (extending the provision repealing continental bills of credit and other bills as legal tender).

110. Act of July 12,1782 , ch. $1, \S 5,1782$ N.Y. Laws 499,500 (relating to debts due to persons within the enemies lines).

111. See Samuel Flagg Bemis, The Diplomacy of the American Revolution 213, 227, 233 (Ind. Univ. Press 1957) (1935) (detailing the British Cabinet's rejection to proposed peace treaties because of inadequate protection of British merchants' rights). 
states to comply with any provision in a treaty designed to coerce states into opening their courts to suits for British debts. ${ }^{112}$ John Jay and John Adams, on the other hand, "saw the debt issue from the standpoint of creditors and within the ethos of capitalism." ${ }^{113}$ They believed that "honesty as well as the burgeoning credit needs of the fledgling undeveloped nation demanded that contracts be honored without reference to the wartime conditions."114 In the end, the American commissioners agreed to language in Article 4 of the treaty declaring that "Creditors on either Side shall meet with no lawful Impediment to the Recovery of the full Value in Sterling Money of all bona fide Debts heretofore contracted." ${ }^{115}$ As for British property confiscated by the states, Article 5 of the treaty merely stated that Congress would "earnestly recommend" that such property be restored. ${ }^{116}$

As expected, the treaty's debt provisions caused an uproar when publicly revealed. Loyalists and British agents who returned to the United States after Cornwallis's surrender were attacked by mobs threatening violence to anyone who proposed to collect British debts. ${ }^{117}$ Many state legislatures followed the lead of the populace and expressed their displeasure with the treaty by passing a number of acts designed to frustrate enforcement of debt obligations. ${ }^{118}$ Massachusetts and Connecticut passed laws permitting juries to deduct wartime interest, while Pennsylvania allowed executions on judgments to be made only in three annual installments. ${ }^{119}$ Even when not barred by statute, creditors continued to find the state courts closed to their claims. The judges of the Georgia courts simply refused to entertain suits for British debts. ${ }^{120}$ In Virginia, the state courts placed cases

112. Holt, supra note 103 , at 1439.

113. Id.

114. Id.

115. The Definitive Treaty of Peace Between His Britannic Majesty and the United States of America, art. 4 (Sept. 3, 1783), reprinted in 2 HUNTER MILLER, 2 TREATIES AND OTHER INTERNATIONAL ACTS OF THE UNITED STATES OF AMERICA, 1776-1818, at 151, 154 (1931).

116. Id. at art. 5.

117. Holt, supra note 103 , at $1440-41$.

118. Id. at $1440-41,1446-47$.

119. Act of May 13, 1784, 1784 Conn. Acts 283 (relating to debts due to persons who had been and remained within the enemies power or lines during the war); Act of Mar. 11, 1785, ch. 24, 1785 Mass. Acts 252 (relieving debtors and preventing them from being obliged to pay interest on debts, if paid by January 1, 1777); Act of Dec. 23, 1784, ch. 169, § 2, 1783 Pa. Laws 412 (directing the mode of recovering debts made before January 1, 1777).

120. In 1783, Georgia Judge George Walton dismissed a writ filed in a British debt case. Other judges quickly followed suit. See Letter from George Hammond to Thomas Jefferson (Mar. 5, 1792), in 1 AMERICAN STATE PAPERS: FOREIGN RELATIONS 196 (Walter Lowrie \& Matthew St. Clair Clarke, eds., 1832-1861) [hereinafter ASP: FOR. REL.]; Letter from Thomas Jefferson to George Hammond (May 29, 1792), in 1 ASP: FOR. REL., supra, at 211. In 1792, a group of Georgia congressmen reported that no suit by a British creditor had resulted in a judgment either for or against a creditor. Letter from William Few et al. to Thomas Jefferson (Apr. 25, 1792), in 1 ASP: FOR. REL., supra, at 236. 
for pre-war debt on the so-called "British docket," where they languished for years without a hearing. John Tyler summed up the attitude of most Virginia judges, declaring "that he would preside at the Trial of no Cause, where a British Subject was plaintiff, and the Plea was [for debt]." commercial center like Philadelphia was not immune from the anger. In 1786, Lord Carmarthen, Britain's secretary of state, complained that Pennsylvania's lawyers, "dreading the resentment of some of the most violent among their Countrymen, have refused to engage in the recovery of these unpopular demands, and the Committee are well assured that not one Action for the payment of an old british debt has been prosecuted in this State." 122

Opposition to repayment of the British debts was more than just economic, however. Many Americans believed that the depredations suffered at the hands of the British during the war more than excused American obligations to pay British creditors. ${ }^{123}$ Americans pointed to the destruction wrought by the English armies, especially in the southern states, as justifying their refusal to pay. George Mason reported that he was repeatedly asked the same question: "If we are now to pay the Debts due to British Merchants, what have we been fighting for all this while?"124 The economic depression of the mid-1780s hardened attitudes even further. A succession of crop failures at home, combined with the collapse of the West Indies trade, meant that few debtors had any money available to retire prewar debts. ${ }^{125}$ For Virginians, in particular, opposition to repayment became an article of faith. Not only had British troops destroyed their lands and homes, the British had compounded the devastation by carrying off thousands of their slaves. The refusal to return the slaves or make good their loss remained an open sore for many Virginia farmers. Adding to the hostility was the refusal of the British to remove their troops from forts along the western frontier, from which they incited the Indians to acts of violence on American settlers. The unwillingness to return the slaves or evacuate the western posts convinced the majority of Virginia's citizens to oppose opening the courts to British plaintiffs. ${ }^{126}$

121. Letter from William Nelson, Jr. to Thomas Jefferson (Nov. 22, 1790).

122. Letter from Lord Carmarthen to John Adams (Feb. 28, 1786), reprinted in 31 JCC, supra note 97, at 786 (providing the state of the grievances complained of by Merchants and other British subjects having estates, property and debts due to them in the several States of America).

123. Holt, supra note 103, at 1443.

124. Letter from George Mason to Patrick Henry (May 6, 1783), in 2 THE PAPERS OF GEORGE MASON 1779-1786, at 771 (Robert A. Rutland ed., 1970).

125. Holt, supra note 103, at 1445.

126. Letter from Thomas Underwood to James Madison (Jan. 4, 1790), in 12 THE PAPERS OF JAMES MAdison 468 (Charles M. Hobson et al. eds., 1979) [hereinafter MADISON PAPERS]; Letter from Walter Jones to James Madison (Feb. 5, 1790), in 13 MADISON PAPERS, supra, at 28; Letter from Thomas Pleasants Jr. to James Madison (July 10, 1790), in 13 MADISON PAPERS, supra, at 269. 
As a result, the difficulties facing British creditors were manifold. Even when they were able to bring suit, juries presented a formidable obstacle to recovery. In a number of cases, juries simply refused to find a verdict in the creditor's favor. ${ }^{127}$ In those rare cases in which creditors succeeded in obtaining a judgment-usually because the suit was brought on a bondjuries deducted interest accrued during the war years even if there was no statutory authority for doing so. ${ }^{128}$ British authorities complained bitterly about the practice, but Thomas Jefferson explained that things were not so bleak as America's creditors painted them. "In one state,"Jefferson noted,

interest during the war is given in every case; in another it is given wherever the creditor, or any agent for him, remained in the country, so as to be accessible; and in the others, it is left to the courts and juries to decide according to their discretion and the circumstances of the case. ${ }^{129}$

The inability of creditors to receive full payment on their claims

127. Years later, Chief Justice Marshall, who himself represented a number of Virginia debtors in cases brought by British creditors, remarked on the fact that "a British debt could not be recovered" in Virginia's courts. Dunlop v. Ball, 6 U.S. (2 Cranch) 180, 182-84 (1804).

Though not a debt case, Bayard v. Singleton, 1 N.C. (Martin) 42 (1787), also demonstrates the hostility of those seeking to enforce rights derived from British subjects. Here, a North Carolina jury was presented with a suit by the daughter of a "Mr. Cornell," an Englishman who had owned property in the state before the Revolution. When hostilities between the Crown and the colonists broke out, Cornell took ship for New York, where he spent the war years living under British rule. Id. at 46 . In December 1777, Cornell executed a deed conveying his North Carolina property to his daughter. Id. This was in spite of the fact that a North Carolina statute had confiscated lands in the hands of British subjects. When the daughter (who had remained in North Carolina) brought suit to recover her father's lands, the jury found for the defendant. Id. at 48.

Similarly, in Moore v. Cherry, 1 S.C. (Bay) 269, 270 (1792), a series of juries in South Carolina repeatedly refused to award damages for the detention of a slave taken from a group of tories during the war years. On defendant's motion for a third trial, Chief Justice Rutledge despaired that "as this was a dispute about property taken during the war, it was best that there should be an end of it." Id. at 270 .

128. See, e.g., Foxcraft \& Galloway v. Nagle, 2 Dall. 132, 133 (Pa. 1791) (deducting seven and one-half years' interest); Hoare v. Allen, 2 Dall. 102, 103-04 ( $\mathrm{Pa} .1789$ ) (deducting wartime interest). Some creditors attempted to avoid having juries hear the case by presenting the court with a case stated. Even this was unsuccessful, however, as the judges themselves either disallowed the claim in its entirety or deducted wartime interest. See, e.g., Bordley v. Eden \& Court, $3 \mathrm{H}$. \& $\mathrm{McH}$. 167, 168 (Md. 1793) (refusing to award interest accrued during the revolution); Court \& Co. v. Vanbibber, 3 H. \& McH. 140, 144 (Md. 1793) (same); Dulany v. Wells, 3 H. \& McH. 20, 23 (Md. 1790) (holding that plaintiffs were not entitled to interest).

Massachusetts and Connecticut allowed courts to deduct wartime interest, however. Act of May 13, 1784, 1784 Conn. Acts 283 (relating to debts due to persons who had been and remained within the enemies power or lines during the war); Act of Mar. 11, 1785, ch. 24, 17831789 Mass. Acts 252-53 (relieving debtors and preventing them from being obliged to pay interest on debts, if paid by January 1,1777 ).

129. Letter from Thomas Jefferson to George Hammond (May 29, 1792), in 1 ASP: FOR. REL., supra note 120, at 201, 214. 
distressed political leaders in both England and the United States. First, the fact that juries were using their power to disallow interest on British debt was not necessarily a welcome development to Americans with commercial interests of their own. This is because certainty in the law was greatly desired by those who thought that the new nation's political stability depended on its commercial development. ${ }^{130}$ An economically advanced nation, able to provide prosperity for its people, would be secure from strife within and better able to withstand assaults from without. Consequently, many feared that the world's commercial traders would avoid doing business in the new American states if the nation's judicial system was regarded as backward. ${ }^{131}$ Such perceptions were bound to increase to the extent that commercial transactions might be altered or set aside by a jury. Americans' attachment to the right to trial by jury in civil cases raised precisely that specter. Moreover, the same populist juries that were impeding the collection of British debt might use their power to disallow unpopular or controversial claims brought by American merchants or traders at some time in the future. ${ }^{132}$

Of more immediate importance, however, was the fact that the impediments placed in the way of creditors' recovery endangered America's relations with foreign countries. ${ }^{133}$ The continuing refusal to honor the terms of the peace treaty came to have very real national security consequences: the British cited the failure of Americans to honor Article 4

130. See JENNIFER Nedelsky, PRIVATE PROPERTy AND THE Limits OF AMERICAN CONSTITUTIONALISM 22-25, 73-75 (1990) (describing the founding generation's concern with protecting property and commercial rights as a means of ensuring stability).

131. Id. at 73-74.

132. Indeed, that possibility seemed imminent when, between August 1784 and August 1786, Massachusetts saw a dramatic increase in debt suits involving a "huge percentage" of the male rural population. A total of six thousand actions for debt were instituted in Connecticut, involving more than twenty percent of the state's taxpayers. Vermont and New Hampshire saw similar increases in debt actions. DAVID P. SZATMARY, SHAYS' REBELLION: THE MAKING OF AN AGRARIAN INSURRECTION 29-30 (1980). There were "thousands of insolvencies" in New York, while six county courts in Virginia handled more than 18,500 cases, most of which were for debt. The fear that debt cases would lead to widespread unrest became one of the motivating factors in deciding to amend the Articles of Conferderation. PETER J. COLEMAN, DEBTORS AND CREDITORS IN AMERICA: INSOLVENCY, IMPRISONMENT FOR DEBT, AND BANKRUPTCY, 1607-1900, at $115,200-01$ (1974).

133. Even a cursory review of the extensive correspondence between ministers of the United States and Britain reveals that the subject of debt remained an obstacle to the normalization of relations well into the decade. See, e.g., Letter From George Washington to Gouverneur Morris (Apr. 7, 1790), in 1 ASP: FOR. REL., supra note 120, at 123 (detailing conversations with the Duke of Leeds concerning the inability of British debtors to recover debts and the complaints of Virginia planters over the refusal of Britain to make good on its promise to compensate for the loss of slaves); Letter from Sir George Hammond to Thomas Jefferson (Mar. 5, 1792), in 1 ASP: FOR. REL., supra note 120, at 193-200; Letter from Thomas Jefferson to Sir George Hammond (May 29, 1792), in ASP: FOR. REL, supra note 120, at 201-16; Letter from Sir George Hammond to Thomas Jefferson (Apr. 6, 1792), in ASP: FOR. REL, supra note 120 , at $200-01$. 
as the justification for their refusal to evacuate forts on the northern and western frontiers long after the signing of the treaty. ${ }^{134}$ The British thus effectively retained control of the lucrative fur trade, ${ }^{135}$ and George Washington was left to lament that they "should have so well grounded a pretext for their palpable infractions!" ${ }^{136}$ The ongoing dispute over the terms of the Treaty of Peace, along with Britain's failure to withdraw its forces from the western frontier, provided ample evidence of the difficulties for foreign relations posed by an uncontrolled jury. ${ }^{137}$ Indeed, the complications for the conduct of foreign relations that might be created by too great a reliance on juries in civil cases had already been demonstrated during the War for Independence, when state admiralty courts, in a

134. See 2 Elliot's DEBATES, supra note 40 , at 490 :

[T] he truth is,--and I am sorry to say it,- that in order to prevent the payment of British debts, and from other causes, our treaties have been violated, and violated, too, by the express laws of several states in the Union.... [I]t is acknowledged on all sides, that many states in the Union have infringed the treaty; and it is well known that, when the minister of the United States made a demand of Lord Carmarthen of a surrender of the western posts, he told the minister with truth and justice, "The treaty under which you claim those possessions has not been performed on your part; until that is done, those possessions will not be delivered up."

The question of pre-war debts was not closed until 1802, when the United States made a lump sum payment of $£ 600,000$ to the British government for the benefit of individual creditors. 3 INTERNATIONAL ADJUDICATIONS, ANCIENT AND MODERN: HISTORY AND DOCUMENTS 359-433 (John Bassett Moore ed., 1929-1936); BradFord PERkINS, The First Rapprochement: ENGLAND AND THE UNITED STATES, 1975-1805, at 138-41 (1955).

135. Letter from George Washington to The Marquis de Lafayette (Aug. 15, 1786), in 58 THE WRITINGS OF GeORGE WASHINGTON 518 (John C. Fitzpatrick ed., 1938) [hereinafter WASHINGTON WRITINGS]. After the war, the British evacuated garrisons along the Atlantic coast without much delay. The British refused to evacuate forts on Lake Champlain, and at Ogdensburg, Oswego, Niagra, Detroit, and Michilimackinac. The forts were originally retained to allow Canadian fur trappers to wind up their affairs. As time went on, however, the Canadians became more reluctant to give up the security the forts provided. 1 SAMUEL ELIOT MORISON, THE OXFORD HISTORY OF THE AMERICAN PEOPLE 374 (1972). To be sure, however, the British had other reasons for keeping the forts. After 1783, Britain abandoned her native American allies. Although the Six Nations continued to harass the American frontier, Canadian officials feared that the Iroquois would soon turn their attentions to Canada's poorly guarded western regions. Holding on to the forts was, therefore, essential to Canada's defense. The British government acceded to Canadian requests and held on to the forts until 1796. DESMOND MORTON, A MILTTARY HISTORY OF CANADA 49 (1985).

136. Letter from George Washington to John Jay (Aug. 1, 1786), in 28 WASHINGTON WRITINGS, supra note 135 , at $501,502$.

137. In discussing the need for federal jurisdiction over diversity cases some years later, Alexander Hamilton argued that special care must be taken in cases where the citizens of other countries were involved. Such care was, Hamilton said, "essential to the preservation of the public faith" as well as "the security of the public tranquility." THE FEDERALIST NO. 80 (Alexander Hamilton). After all, it was probable that "an unjust sentence against a foreigner, where the subject of controversy was wholly relative to the lex loci, would ... if unredressed, be an aggression upon his sovereign, [to the same extent] as one which violated the stipulations of a treaty, or the general law of nations." Id. 
concession to the revolutionary fervor of the times, abandoned centuries of traditional admiralty practice and instead utilized juries to try prize cases.

\section{B. STATE CoURT JURIES AND PRIZE CASES}

In time of war, governments frequently issued letters of marque to privateers authorizing them to cruise the high seas, seizing ships or other property belonging to the enemy. A captured vessel was "libeled" in the admiralty court of the captor's nation, where the question of "prize or no" was decided. If the captured vessel or cargo were found to be the property of a belligerent, the captor was entitled to a share of the proceeds. ${ }^{138}$

With the rise of privateering came the development of a complex, but relatively uniform, body of prize law. The most important feature of this law was its international character. Although modified by treaties in some respects, most maritime nations adopted identical rules for determining whether a particular capture was to be condemned as prize as well as the means for distributing the proceeds. ${ }^{139}$ Of necessity, therefore, prize courts were involved in the determination of important questions of international law. Whether a ship belonged to a belligerent, carried contraband goods, or belonged to a neutral were all issues having potentially explosive consequences. ${ }^{140}$

Like their English counterparts, the colonial vice-admiralty courts tried prize cases without the use of juries. The several wars between England and various European powers during the first half of the eighteenth century ensured that the colonial vice-admiralty courts were well acquainted with prize law and procedure. Indeed, between 1702 and 1763, approximately one-third of the vice-admiralty courts' dockets were taken up by prize cases. ${ }^{141}$ The assertion of prize jurisdiction by the vice-admiralty courts aroused little controversy in the colonies, mainly because no common-law court had ever been thought to have the right to hear prize cases. ${ }^{142}$

138. The right to the prize vested in the first instance in the government of the captor's nation. Beginning in the Middle Ages, however, governments authorized the granting of a portion of the proceeds to the captor as a reward for services rendered. 1 JAMES KENT, COMMENTARIES ON AMERICAN LAW 96 (Leonard W. Levy ed. , 1971) (1826).

139. A number of treatises were written during the seventeenth and eighteenth centuries describing the elements of prize law. Among the most famous of these was Hugo Grotius' $D e$ Jure Praedae Commentarius, published in 1604. Others included Charles Molloy's DE JURE MARITIMo ET NaVAli (1676), Richard Lee's A TREATISE OF CAPTURES IN WAR (1759), and Emmerich de Vattel's THE LAW OF NATIONS (1760).

140. The entire system of prize and privateering no doubt seems strange to the modern reader. Yet the arming of private vessels was an essential means of increasing the size of a nation's navy in wartime. Allowing both military and private vessels to seize enemy ships, and to keep a portion of the proceeds, was an incentive to an aggressive military endeavor.

141. Harrington, Vice-Admiralty Part II, supra note 83, at 330.

142. See, e.g., Sasportas v. Jennings \& Woodrop, 1 Bay 470, 475-76 (S.C. 1795) (holding that prize cases and their incidents belong exclusively to the admiralty). 
However, with the outbreak of war between England and the colonies, most colonial vice-admiralty courts ceased to function. This was mainly because their close connection with the enforcement of the revenue acts made the courts a prime target for the anger of the mob. Nevertheless, the need to dispose of prizes taken by privateers and ships of the Continental navy made it necessary that some court be vested with prize jurisdiction. As a result, in November 1775, Congress passed a resolution "recommending" that each state create a court for the adjudication of prize cases. ${ }^{143}$ However, in a move that was to have far-reaching consequences for the conduct of foreign relations, Congress also recommended that "all trials" in prize cases be "by a jury, under such qualifications as the respective legislatures shall seem expedient. ${ }^{\text {144 }}$

Providing for jury trials in prize cases certainly neutralized much of the invective hurled against the old vice-admiralty courts. Yet in bowing to the revolutionary spirit of the times, Congress and the states created a whole new set of problems: state court juries, lacking the expertise in the law of prize held by the vice-admiralty judges, often ignored well-established principles of the laws of nations and adjudged ships taken by local captains and crews to be lawful prize. Throughout the war years, therefore, both neutrals and allies complained that property belonging to their citizens had been unjustly condemned by state court juries. ${ }^{145}$ America's political leaders thus worried about the damage that uncontrolled juries were capable of

143. Resolution of Nov. 25, 1775, in 3 JCC, supra note 96, at 373-74.

144. Id. Most states set up courts in response to the congressional resolves. Some acted by creating new courts exclusively for prize cases, while others established admiralty courts with all the powers traditionally exercised by the admiralty in England. Still others simply continued the old vice-admiralty courts, albeit with new personnel. Harrington, Vice-Admirally Part II, supra note 83 , at 340 .

145. Two Massachusetts cases indicate the difficulties presented by juries.

In October 1781, The Nostra Seigniora was brought into Boston and sold, even before she was libeled in the state admiralty court. The vessel's Spanish owners contended that the ship and cargo were Spanish property and, thus, not liable to forfeiture. Nonetheless, a state court jury determined that the cargo was subject to forfeiture. On appeal, Congress ordered that the ship and cargo be restored to the owners, but the state court apparently refused to comply. The owners were forced to file an action for trover in the common-law court. After two more trials before juries, they were eventually awarded damages against the captors. See HENRYJ. Bourguinon, The First Federal Court: The Federal appellate Prize Court of the AMERICAN REVOLUTION 1775-1787, at 230-31 (1977) (discussing the Nostra Seigniora da Solidade e St. Miguel e Almas (Randall v. Doe).

Two years later, another Spanish ship, The St. Antonio, was taken near the mouth of the Mississippi River. The captors brought the ship into Boston, where a jury declared that the ship was British. This decision spawned a flurry of letters from French and Spanish diplomats, complaining of the treatment of allied and neutral vessels at the hands of American privateers. The Court of Appeals in Cases of Capture reversed the state court decree and ordered the vessel restored to her owners. The state court refused, and the owners were forced to sue for damages at common law, but their claim was rejected by a jury in the Massachusetts superior court. See id. at 231-35 (discussing the St. Antonio case). 
doing to the country's reputation at precisely the moment the nation needed its allies most.

Perhaps more important for the future of the right to trial by jury, however, was the fact that state court admiralty juries also frequently condemned property belonging to Americans. These verdicts were often the result of local bias or prejudice, favoring local captors against out-of-state merchants. Among the most famous examples of such verdicts are those rendered in the Lusanna ${ }^{146}$ and the Active cases. ${ }^{147}$ In both cases, American merchants fought for decades to have the verdict of a state court admiralty jury overturned.

The experience with juries in debt and admiralty cases thus left many of the founders with a firm belief that the role of juries in certain classes of cases needed to be carefully constrained. It was not merely that jury verdicts tended to cause conflict with foreign nations, although admiralty cases, in particular, had important foreign relations consequences. ${ }^{148} \mathrm{~A}$ far more

146. In the fall of 1777 , the brigantine McClary, a privateer outfitted in New Hampshire, captured the Lusanna, a ship owned by Elisha Doane and several other merchants from Massachusetts. After a trial in the New Hampshire admiralty court, a jury found for the captors. The Lusanna was thus condemned and sold. The Lusanna's owners took an appeal to Congress, which reversed the state court decree and ordered the vessel restored to her owners. The state court refused to comply with the congressional court's decree. The New Hampshire legislature entered the fray a few months later, denying that Congress or its courts had any power to reverse the verdict of a jury, and promising to resist any effort to put the congressional decree into effect. So things remained for almost twenty years. After the ratification of the Constitution and the creation of the new federal courts, Elisha Doane's administrators commenced an action in the New Hampshire district court seeking to have the decree of the congressional court enforced. The case eventually made its way to the United States Supreme Court, which held that the newly created federal courts had the power to enforce the decrees of the old congressional Court of Appeals and awarded damages to the Lusanna's owners. Penhallow v. Doane's Adm'rs, 3 U.S. (3 Dall.) 53 (1795).

147. In September 1778, Gideon Olmstead, a seaman from Connecticut, and several others were captured by the British and taken to Jamaica. From there, they were put aboard the sloop Active and made to assist in bringing the vessel to New York, which was then still in British hands. While en route, Olmstead and the others rose up against the British crew and took the vessel. They began to steer for Egg Harbor, New Jersey. When in sight of the harbor, they came upon the brig Convention, a Pennsylvania privateer, commanded by Thomas Houston. The Convention seized the Active and brought the sloop into Philadelphia, where she was condemned as prize to the crew of the Pennsylvania ship. The Connecticut men were given only one-fourth of the proceeds. Arguing that they were well-equipped to bring the Active safely into an American port, Olmstead and the others appealed to the Congress, which overturned the state court verdict. United States v. Peters, 9 U.S. (5 Cranch) 115, 118-120 (1809). George Ross, the admiralty judge, refused to comply with the congressional decree. Ross contended that "although the court of appeals have full authority to alter or set aside the decree of a judge [,] ... the finding of the jury in the cause does establish the facts in the cause without reexamination or appeal." Id. at 120. The judge then ordered that the state's share of the proceeds be turned over to the state treasurer. There matters stood for over twenty years, as Olmstead waged a determined effort to obtain compliance with the congressional decree. It took thirty years and repeated petitions in both the state and federal courts before Olmstead finally succeeded in obtaining compliance with the congressional court's decree. Id.

148. The comments in the state ratifying conventions indicate that the actions of juries in 
pressing concern was that the jury's law-finding function had the potential to damage the commercial affairs of a growing nation. Many in the commercial classes were convinced that foreigners would be unlikely to invest in a society whose legal institutions appeared unreliable or capricious. They worried that unrestrained juries, bringing a populist approach to the adjudication of commercial cases, would not present an environment conducive to foreign investment. ${ }^{149}$ They saw the jury as an obstacle to commercial progress, and thus cast about for some solution.

\section{JUREES AND THE CONSTITUTION}

The Constitutional Convention was originally scheduled to convene on May 14, 1787, but it was not until May 25 that enough delegates appeared in Philadelphia for the Convention to begin its work. ${ }^{150}$ In the interim, a series of meetings between delegates from Virginia and Pennsylvania convinced many delegates that any plan to amend the Articles of Confederation would be futile. As a result, when the Convention finally convened, Virginia's Edmund Randolph introduced a plan for a new national government. This "Virginia Plan" included a tripartite frame of government, consisting of a bicameral legislature, a "national executive," and a "national judiciary.",

the state courts were one of the primary purposes for eventually vesting federal courts with jurisdiction over admiralty and maritime claims. Governor Edmund Randolph's remarks in the Virginia convention were representative of the feelings of many:

Cases of admiralty and maritime jurisdiction cannot, with propriety, be vested in particular state courts. As our national tranquility and reputation, and intercourse with foreign nations, may be effected by admiralty decisions; as they ought, therefore, to be uniform; and as there can be no uniformity if there be thirteen distinct, independent jurisdictions,--this jurisdiction ought to be in the federal judiciary.

3 ELLIOT'S DEBATES, supra note 40, at 571; see also id. at 203 (statement of Gov. Edmund Randolph, Va.); id. at 532 (statement of James Madison, Va.).

149. See 3 Elliot's DEBATES, supra note 40 , at 538 :

The great desiderata are public and private confidence. No country in the world can do without them. Let the influx of money be ever so great, if there be no confidence, property will sink in value, and there will be no inducement or emulation to industry. The circulation of confidence is better than the circulation of money. Compare the situation of nations in Europe, where justice is administered with celerity, to that of those where it is refused, or administered tardily. Confidence produces the best effects in the former. The establishment of confidence will raise the value of property, and relieve those who are so unhappy as to be involved in debts. If this be maturely considered, I think it will be found that, as far as it will establish uniformity of justice, it will be of real advantage to such persons.

150. 1 MAX FarRand, ReCORDS OF THE FEDERAL CONVENTION OF 1787, at 1 (1966) [hereinafter FARRAND]. The Convention actually met from May 25 until September 17, 1787. Twelve States were represented; Rhode Island declined to attend.

151. Id. at 18-23. 
The Convention devoted most of its time that summer to debating the composition of the executive and legislative branches. It was not until these issues were settled that the delegates turned their attention to the problem of the national judiciary. Although the Convention quickly agreed to establish a "supreme national tribunal," many delegates were unwilling to support the creation of lower federal courts for fear that they would encroach upon the rights and powers of the states. They argued that state courts could be used to try federal cases in the first instance. The federal interest in uniformity would be assured by vesting jurisdiction over appeals in the Supreme Court. Others, however, argued that an extensive system of lower courts, having jurisdiction over important issues of national concern, was necessary if the new nation was to survive. ${ }^{152}$ The Convention ultimately settled on a compromise proposed by James Madison: rather than mandate the creation of lower federal courts, the Constitution would provide instead "that the National Legislature be empowered to institute inferior tribunals." 153 In so doing, the delegates succeeded in postponing the problem of whether to establish lower federal courts to another day. After an extensive debate, the Convention approved a final draft of the Constitution on September $17,1787 .{ }^{154}$ Article III of the new Constitution contained the provisions respecting the establishment of the judiciary. Among other things, Section 2 gave the federal courts jurisdiction over cases "arising under" the Constitution or laws of the United States, as well as admiralty matters and cases "between Citizens of different States." 155

It is important to note that in discussing the outlines of a national judiciary, the delegates paid very little attention to the right to a jury trial in

152. The original Virginia plan provided for "one or more supreme tribunals" along with an extensive system of lower federal courts distributed throughout the nation and empowered to hear and determine all "questions which may involve the national peace and harmony." Id. at 21-22. Little discussion attended this proposal and it was tentatively adopted on June 4, 1787, with the delegates agreeing to establish a "National Judiciary" consisting of "one supreme tribunal, and of one or more inferior tribunals." Id. at 95, 104-05. A day later, however, John Rutledge of South Carolina, aided by Roger Sherman of Connecticut, moved to reconsider the question. Id. at 118, 124. Rutledge argued that review of state court decisions by a federal supreme court would be enough to protect federal interests. State courts should be left to decide all cases in the first instance. National rights and uniformity of judgments would be preserved by allowing an appeal to the supreme national tribunal. Rutledge's proposal gained support from other delegates concerned about the expense of having a set of federal courts duplicating the work of state trial courts. James Madison opposed Rutledge's suggestion. Madison argued that the Supreme Court could not be an effective control over biased state court juries or judges. Unless it was willing to rehear the case in its entirety, the Supreme Court would, in the system proposed by Rutledge, be obligated to return the case to the state court for a rehearing. State courts would again control the result. The parties would then be required to bear the expense of a new trial and bring witnesses long distances to the place of retrial. Id. at $124-25$.

153. Id. at 125.

154. 2 id. at 644.

155. U.S. CONST. art. III, $\$ \S ~ 1-2$. 
civil cases. Indeed, it was not until September 12, 1787, almost four months after the Convention began, that Hugh Williamson of North Carolina "observed to the House that no provision was yet made for juries in Civil cases and suggested the necessity of it." 156 The question was briefly considered, but no action taken, for it was thought that "[ $t]$ here are many cases where juries are proper which cannot be discriminated" and that "the [national] Legislature may be safely trusted" to provide for them. ${ }^{157}$ Elbridge Gerry and Charles Pinckney made another attempt to insert a right to a civil jury into the final text of the Constitution three days later, on September 15. They moved that Article III be amended to provide that "trial by jury shall be preserved as usual in civil cases." well. Nathaniel Gorham despaired that the "constitution of Juries is different in different States and the trial itself is usual in different cases in different States," thus making it impossible to provide a general rule. ${ }^{159}$ Charles Cotesworth Pinckney urged the same objection, arguing that the inclusion of such a clause in the Constitution would be "pregnant with embarrassments." 160

As a result, the Constitution went to the states without explicit mention of the right to jury trial in civil cases. Although it contained a provision for jury trials in criminal cases, Article III did not guarantee a jury of the vicinage. ${ }^{161}$ Antifederalists seized on these omissions in an attempt to show that the framers had embarked upon a plan to subvert popular government. Although federalists repeatedly argued that Congress could be trusted to preserve the right to jury trial, most antifederalists urged rejection of the Constitution until the right was preserved in the document itself. ${ }^{162}$ The antifederalist opposition was so strong that in the end at least seven state ratifying conventions called for amendments to the Constitution guaranteeing the right to trial by jury in civil cases.

\section{THE RATIFICATION DEBATE}

The ratification debate took place in public houses as well as the public press. In the pamphlet war that began almost immediately after the Convention adjourned, the antifederalists raised doubts about a variety of constitutional provisions, and the judiciary article figured prominently in much of the criticism. Opponents complained that the Constitution's broad grant of jurisdiction to the federal courts would leave the state courts with

156. 2 FARRAND, supra note 150 , at 587.

157. Id. at 588.

158. Id. at 628 .

159. Id.

160. Id.

161. U.S. CONST. art. III, § 2, cl. 3.

162. See infra text accompanying notes $177-99$ (describing antifederalist objections to Constitution's lack of jury trial guarantee). 
very little to do. Among the complaints directed against the judiciary was that the immense powers given to federal courts would result in the eventual consolidation of all judicial power in the federal system. ${ }^{163}$ The courts' diversity jurisdiction also became a target because of the fear that citizens would be forced to litigate in courts far removed from their place of residence. ${ }^{164}$ Others complained about the expense that would be incurred in creating a new federal court system, ${ }^{165}$ while a few worried about the wisdom of giving federal judges life tenure. ${ }^{166}$ Without a doubt, however, the most serious charge leveled against the Constitution was that it abolished the right to trial by jury in civil cases.

The antifederalists were able to make this argument for two reasons. First, there was no mention of the right to civil jury trial anywhere in the Constitution itself. While Article III had made some provisions for jury trials in criminal cases, it was silent as to whether the same right was preserved in civil cases. ${ }^{167}$ Even more ominous, critics noted, was the fact that the judiciary article provided that the Supreme Court would have "appellate Jurisdiction, both as to Law and Fact." ${ }^{.168}$ Such a provision, they said, was clearly designed to displace the common law and introduce civil law modes

163. See, e.g., Essay of Brutus, N.Y. J., Feb. 14, 1788, reprinted in 2 THE CoMPLETE ANTIFEDERALIST 426, 427 (Herbert J. Storing ed., 1981) [hereinafter ANTI-FEDERALIST] (arguing that "as the general government acquires power and jurisdiction, by the liberal construction which the judges may give the constitution," the states will lose their rights, "until they become so trifling and unimportant, as not to be worth having").

164. See, e.g., Letter III (Oct. 10, 1787), in LETTERS FROM THE FEDERAL FARMER TO THE REPUBLICAN 22-23 (Walter H. Bennet ed., 1978) (warning that creating new courts would open "a new scene of expensive law suits" and allow "foreigners and citizens of different states to "drag each other many hundred miles into the federal courts"); see also Essay of Brutus, supra note 163, at 427 (discussing the dangers of concurrent jurisdiction).

165. Echoing sentiments expressed by Roger Sherman at the Philadelphia Convention, $A n$ Officer of the Late Continental Army warned that the new government would be expensive beyond any ever experienced: “[T] he judicial department alone, with its concomitant train of judges, justices, chancellors, clerks, sheriffs, coroners, excheators, state attornies and solicitors, constables, elc. in every state and every country in each state, will be a burden beyond the utmost abilities of the people to bear." An Officer of the Late Continental Army, INDEP. GAZETrEeR (Phila.), Nov. 6, 1787, reprinted in 3 ANTI-FEDERALIST, supra note 163, at 94 (emphasis in original); see also Centinel II, FREEMIAN'S J. (Phila.), Oct. 24, 1787, reprinted in 2 ANTI-FEDERALIST, supra note 163, at 149 (warning of the "enormous" expense that would result "if an inferior court, whose judges have ample salaries, be established in every county").

166. Brutus warned that those invested with the judicial power under the new Constitution would be placed "in a situation altogether unprecedented in a free country" in that they are "rendered totally independent, both of the people and the legislature." Essay of Brutus, supra note 163 , at $417-18$. Giving judges life tenure meant that " $[n]$ o errors they may commit can be corrected by any power above them, if any such power there be, nor can they be removed from office for making ever so many erroneous adjudications." Id.

167. See, e.g., Centinel I, INDEP. GazeTteer (Phila.), Oct. 5, 1787, reprinted in 2 ANTIFEDERALIST, supra note 163 , at 143.

168. U.S. CONST. art. III, $\$ 2$, cl. 2. 
of proceeding into the federal system. ${ }^{169}$ As a result, antifederalist writers seized on the omission to urge rejection of the Constitution.

\section{A. THE ANTIFEDERALIST COMPLAINT}

It is difficult to determine the precise motives of any of the participants in the ratification debate. It is also dangerous to assume that the antifederalists were monolithic in their outlook or aims. ${ }^{170}$ On one level, the desire for more certain protections for individual rights was clearly a function of many antifederalists' devotion to the ideals of the Revolution. Still, some of the antifederalist complaints concerning jury trials in civil cases were based, to some extent, on a desire to obtain political advantage in the ratification debate. There is, in fact, a great deal of evidence tending to show that the antifederalist complaint about the lack of a bill of rights was often a makeweight designed to attract broader support than other, more arcane or technical arguments might have done. Thus, while many of the Constitution's opponents possessed a deeply held Whiggish suspicion of centralized government, it is equally clear that a considerable portion of the opposition was motivated by the fact that its adoption portended a decrease in the power of the state governments and an attendant decline in their own political influence. ${ }^{171}$

169. Essay of a Democratic Federalist, PA. HERALD (Phila.), Oct. 17, 1787, reprinted in 3 ANTIFEDERALIST, supra note 163, at 58 (arguing that the proposed constitution effectively abolished trial by jury because it allowed appeals of fact). A more moderate view was stated by Richard Henry Lee:

[T] he jury trial is not secured at all in civil causes. Though the convention [has] not established this trial, it is to be hoped that congress, in putting the new system into execution, will do it by legislative act, in all cases in which it can be done with propriety. Whether the jury trial is not excluded [in] the supreme judicial court is an important question. By Art. 3, Sec. 2, [in] all cases affecting ambassadors, other public ministers, and consuls, and in those cases in which a state shall be a party, the supreme court shall have [original] jurisdiction. In all the other cases beforementioned, the supreme court shall have appellate jurisdiction, both as to law and fact.... By court is understood a court consisting of judges; and the idea of a jury is excluded. This court, or the judges, are to have jurisdiction on appeals, in all the cases enumerated, as to law and fact;... however, under the exceptions and powers to make regulations, congress may, perhaps, introduce the jury, to try the fact in most necessary cases.

RICHARd HENRY LEe, OBSERVATIONS LEAdiNG TO A FAIR EXAMINATION OF THE SYSTEM OF Government Proposed by tHe LATE Convention . . . IN A NuMBer of LeTters from the FEDERAL FARMER TO THE REPUBLICAN (1787), reprinted in 2 ANTI-FEDERALIST, supra note 163, at 244 (Lee's authorship is disputed).

170. See SAul CoRnel, THE OTHER Founders $51-120$ (2000).

171. See, e.g., Merrill Jensen, The Making of the AMERICAN CONSTItution 131 (1964) (discussing how the omission of a Bill of Rights alarmed opponents to the Constitution); JACK

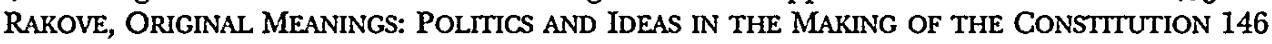
(1996) (noting several proposed constitutional provisions that the antifederalists considered tyrannical); ROBERT A. RUTLAND, THE ORDEAL OF THE CONSTITUTION 213 (1966) (noting the 
Those who raised objections to the new Constitution on the grounds that it failed to make adequate provision for jury trials in civil cases "struck a very responsive chord" in the public. ${ }^{172}$ That this is the case is evidenced by the fact that federalist writers were forced to devote a large part of their efforts to defending the reasonableness of that omission. Alexander Hamilton had to admit that " $[t]$ he objection to the plan of the convention, which has met with most success in this state, and perhaps in several of the other states, is that relative to the want of a constitutional provision for the trial by jury in civil cases." ${ }^{173}$ As a result, he devoted Federalist No. 83 entirely to the purpose of demonstrating that the lack of any mention of the right to jury trial in civil cases was not sufficient grounds for rejecting the entire document. ${ }^{174}$ Thomas Jefferson, who generally supported the Convention's efforts (although he remained rather aloof from the ratification debate), regretted the fact that the Convention had failed to provide adequate protection for "a trial by jury in all cases determinable by the law of the land." ${ }^{175}$ Jefferson rejected the idea that a lack of uniformity in the right to a civil jury trial meant that no provision should be made for it in the text of the Constitution. It was a "hard conclusion," he wrote, to say that "because some have been so incautious as to abandon this mode of trial, therefore the more prudent states shall be reduced to the same level of calamity." Rather, it would have been "much more just and wise to have concluded the other way that as most of the states had judiciously preserved this palladium, those who wandered should be brought back to it, and to have established the general right instead of general wrong."176

Whatever their motives, it is clear that in the end, the antifederalist critique captured the attention of the public mind, thus setting the terms of the ratification debate. It is also important to note that antifederalist support for the civil jury was far more substantive than an argument that civil juries were merely "a good thing." civil jury's law-finding function at the center of their critique, arguing that the unrestrained jury provided the surest and best protection for the citizen against arbitrary and unjust enforcement of the laws. In essence, the antifederalists recalled the jury's long history in both England and the

opposition to the Constitution at the New Hampshire convention).

172. Wolfram, supra note 18 , at 667-68.

173. THE FEDERALIST No. 83 (Alexander Hamilton).

174. Id.

175. Letter from Thomas Jefferson to Francis Hopkinson (Mar. 13, 1789), reprinted in THE PAPERS OF Thomas JefFerson 649 (Julian P. Boyd ed., 1957).

176. Letter from Thomas Jefferson to James Madison (Dec. 20, 1787), reprinted in THE PAPERS OF THOMAS JEFFERSON, supra note 175 , at 440.

177. Edith Guild Henderson, The Background of the Seventh Amendment, 80 HARV. L. REV. 289, 292 (1966); cf. Wolfram, supra note 18, at 670 \& n.85 (arguing that the "pyrotechnic style" used by all sides in the debate over the right to jury trial "should not be permitted to obscure the real substance of the arguments being made in favor of, and against, the civil jury trial"). 
colonies, highlighting its value as a bulwark of liberty. In their view, the jury was the most effective means by which the overreaching of judges, legislators, or the executive might be prevented. The fact that juries had long used their power to ignore or "rewrite" the law as stated by the judges was cited as a benefit rather than a burden on the legal system, for such a power tended to ensure that the law conformed to the will of the people. Indeed, it was precisely because juries would bring in decisions at odds with those of the judges that they were valuable as a means of ensuring that a judiciary populated by appointees with life tenure could still remain in touch with the founders' democratic ideals.

For many antifederalists then, the right to trial by jury was an essential defense against arbitrary rule and government corruption, and its omission from the text of the Constitution was a fatal flaw. Consequently, they used every opportunity to press for the inclusion of some guarantee for civil juries in the Constitution. They launched a two-fold rhetorical offensive. On a theoretical plane, they reminded Americans of the jury's grand history as a sure defense against arbitrary rule. On a more practical level, however, the antifederalists pointed out the very real economic and political consequences that would result from a failure to protect a right to trial by jury in civil cases. In making their arguments, antifederalists pointed to several specific instances in which they believed the civil jury was necessary to protect the rights of the individual. Each of these was integrally connected to the jury's power to find both law and fact.

\section{Protection Against Abuse by Government Officials}

Antifederalists argued that the jury was essential in cases involving suits between a citizen and the national government as well as suits brought by the government under the revenue laws. While the criminal jury remained the most obvious protection against an oppressive prosecution, the civil jury remained, they said, an essential weapon against arbitrary enforcement of the government's laws. A citizen's right to sue the officers of the government for violations of his rights was a nullity without the right to put the case to a jury of his peers. Antifederalists held up Entick v. Carrington and Wilkes $v$. Wood, two cases in which aggrieved citizens recovered substantial damages from royal officials who violated their rights, as vivid examples of the benefits of trial by jury in civil cases. ${ }^{178}$ The antifederalist writer known as the Democratic Federalist reminded his readers of a case in which a constable with a warrant to search for stolen goods "pulled down the clothes of a bed in which there was a woman and searched under her shift."

178. See supra notes 58-59 and accompanying text (describing Entick and Wilkes and their impact on the history of the right to jury trial in England).

179. Essay of a Democratic Federalist, PA. HERALD, Oct. 17, 1787, reprinted in 3 ANTIFEDERALIST, supra note 163, at 58, 61 (referring to Ward's Case, Reports of and Pleas of Assises at Yorke, 1581-1650, at 44 (1651)). 
was later able to obtain a judgment against him was used as evidence of the value of the jury in protecting the populace from government overreaching:

Suppose, therefore, that the military officers of Congress, by a wanton abuse of power, imprison the free citizens of the United States; suppose the excise or revenue officers . . commit similar or greater indignities, in such cases trial by jury would be our safest resource, heavy damages would at once punish the offender and deter others from committing the same. ${ }^{180}$

Without such a right, therefore, a "lordly court of justice" sitting without a jury would be more "ready to protect the officers of government against the weak and helpless citizens." "What refuge shall we then have," the Democratic Federalist asked, "to shelter us from the iron hand of arbitrary power?"181

\section{Protection Against Unjust Legislation}

A far more immediate concern, however, was the fear that the national government would utilize its legislative power to oppress the citizenry. Without specific protection for the jury, antifederalists argued, Congress might enact tax or revenue statutes that allowed a customs or excise officer to prosecute violations in federal courts without juries. Such an argument, of course, rekindled all the old complaints about the colonial vice-admiralty courts. Indeed, in the ill-fated North Carolina convention of 1788, James M'Dowall implied that the denial of jury trials under the Stamp Act was the primary cause of the Revolution:

What made the people revolt from Great Britain? The trial by jury, that great safeguard of liberty, was taken away, and a stamp duty was laid upon them. This alarmed them, and led them to fear that greater oppressions would take place. We then resisted. It involved us in war, and caused us to relinquish a government which made us happy in every thing else. The war was very bloody, but we got our independence. We are now giving away our dear bought rights. We ought to consider what we are about to do before we determine. ${ }^{182}$

While M'Dowall's rhetoric might have been a bit excessive, it revealed the fact that most antifederalists looked to the civil jury to exercise its lawfinding function and nullify tax laws that were considered unjust or unwise. ${ }^{183}$

180. Id.

181. Id. But cf. THE FEDERALIST No. 83, (Alexander Hamilton) ("[w]ilful abuses of a public authority, to the oppression of the subject, and every species of official extortion, are offences against the government; for which, the persons who commit them, may be indicted and punished according to the circumstances of the case.").

182. 4 ELLIOT'S DEBATES, surpa note 40, at 143.

183. To be sure, the antifederalist position on this point was quite subtle. For obvious reasons, it would not do to assert too directly the power of a jury to disregard laws enacted by a 


\section{Protection Against Biased or Corrupt Judges}

The antifederalists also urged the necessity of the civil jury as a means of preventing abuse of the citizenry by corrupt or incompetent judges. This argument was raised by Massachusetts's Elbridge Gerry during the brief discussion of civil juries at the Philadelphia Convention, when he "urged the necessity of Juries to guard agst. Corrupt Judges." 184 Gerry later attributed his refusal to sign the draft of the Constitution to the fact that the "rights of the Citizens were... rendered insecure... by the general power of the Legislature ... to establish a tribunal without juries, which will be a Starchamber as to Civil cases." ${ }^{255}$ Others echoed Gerry's concern. One Pennsylvania antifederalist warned that in the absence of a jury, the trial of "questions of property between man and man" would be occasioned by "oppression, injustice and partiality." ${ }^{186}$ Another Pennsylvanian went a bit further, however, and accused James Wilson of conspiring with the hated Judge Jeffreys to eliminate the right to a jury in civil cases and replace it with trial "by corrupted judges." ${ }^{\text {187 }}$ Still other antifederalists injected a bit of class warfare into the debate and argued that even the most honest judge posed a danger to the public unless he was properly restrained by a civil jury. Judges were, after all, usually members of the upper class and would have a "bias towards those of their rank and dignity. ${ }^{188}$ The jury, "therefore, preserves in the hands of the people, that share which they ought to have in the administration of justice, and prevents the encroachments of the more powerful and wealthy citizens." 189

In fact, both federalists and antifederalists agreed that the jury could serve as a check on judicial corruption. During the Pennsylvania ratifying convention, William Findley argued that "the Liberties of the People are always safest when Juries (who never go wrong by System) are called in and control the Conduct of the Judges." noted that while jurors might "return a mistaken, or ill founded verdict,"

democratic legislature. Nonetheless, antifederalists repeatedly juxtaposed Congress' power to levy taxes with the Constitution's failure to make explicit provision for the right to juries in civil cases. See, e.g., $3 \mathrm{id}$. at 218 (statement of James Monroe, Va.) (arguing powers of Congress are too broad); id. at 503, 512-13, 577-78 (statement of Patrick Henry, Va.) (arguing Congress would have the power to impose taxes and then abolish jury trials in revenue cases); $i d$. at 441 42 (statement of George Mason, Va.) (same).

184. 2 FARRAND, supra note 150 , at 587 .

185. Id. at 663.

186. 1 PENNSYLVANIA AND THE FEDERAL Constitution: 1787-1788, at 154 (John Bach McMaster \& Frederick D. Stone eds., 1888).

187. One of the People, INDEP. GAZETTEER (Phila.), Dec. 11, 1787.

188. Centinel II, FREEMAN'S J. (Phila.), Oct. 27, 1787, reprinted in 3 ANTI-FEDERALIST, supra note 163 , at 143,149 .

189. Id.

190. R. Carter Pittman, Jasper Yeates's Notes on the Pennsyluania Ratifying Convention, 22 WM. \& MARY. Q. 301, 311 (1964). 
their errors were unlikely to be "systematical" as would be the errors of a judge. ${ }^{191}$ Even Alexander Hamilton, who expended a great deal of effort in attempting to convince his readers that the lack of specific guarantees for the civil jury right did not imperil individual liberty, was forced to admit that the "strongest argument in its favour is, that it is a security... against corruption." After all, it was easier to corrupt a "standing body of magistrates than a jury summoned for the occasion."193 Moreover, even though it was possible to taint an individual jury (through selection by a sheriff intent on serving "the purpose of a party"), ${ }^{194}$ the jury system still operated as a significant deterrent to corruption of the legal system. After all, "where the jury have gone evidently wrong, the court will generally grant a new trial, and it would be in most cases of little use to practice upon the jury, unless the court could be likewise gained." ${ }^{195}$ In order to fix a trial, then, both judge and jury would need to be corrupted. In Hamilton's view, the jury provides a "double security," which preserves the "purity of both institutions." ${ }^{196}$ Nonetheless, Hamilton found that the obstacles to creating a uniform rule for jury cases precluded its inclusion in the Constitution itself.

\section{Protection of Economic Rights}

The antifederalists' greatest fear was that the new federal courts would try cases brought by British creditors to recover pre-Revolutionary War debts without empanelling juries. As noted above, British merchants had thus far experienced a great deal of difficulty in attempting to bring suits for debt in the state courts. The Constitution's grant of diversity jurisdiction now promised to open the federal courts to such claims and made the need for debtor protection even more urgent, especially since many antifederalists assumed that debtors would be forced to litigate debt cases in courts that were quite remote from their places of abode. Virginia's Richard Henry Lee was particularly troubled by the fear that creating an extensive system of lower federal courts would lead to

the vexatious and oppressive calling of citizens from their own country... to be tried in a far distant court, and as it may be without a jury, whereby in a multitude of cases, the circumstances of distance and expence may compel numbers to submit to the most unjust and ill-founded demand. ${ }^{197}$

191. 2 ElLIOT'S DEBATES, supra note 40, at 516.

192. THE FEDERALIST NO. 83 (Alexander Hamilton).

193. Id.

194. Id.

195. Id.

196. Id.

197. Richard Henry Lee $\&$ the Constitution, in 8 THE DOCUMENTARY HISTORY OF THE RATIFICATION OF THE CONSTITUTION 59, 66 (Merrill Jensen ed., 1976) [hereinafter DHRC]. 
Moreover, the fact that the Constitution prohibited the states from passing any law "impairing the Obligation of Contracts," or making "any Thing but gold and silver Coin a Tender in Payment of Debts," 198 made the right to a jury trial the debtor's last hope for relief from the claims of an aggressive creditor. ${ }^{199}$

It was this economic argument that was to assume center stage in many of the debates over the right to jury trial in the state ratifying conventions.

\section{B. THE DEBATE IN THE STATE CONVENTIONS}

When the proposed Constitution went before the state ratifying conventions in the fall of 1787 , antifederalists repeatedly decried the lack of specific guarantees for civil juries, particularly where economic rights were concerned. Federalists, on the other hand, issued vague assurances that Congress would protect the right to jury trial through legislation. As might have been expected, therefore, antifederalists repeatedly warned of the economic and political dangers that would ensue if the right to a civil jury was left unprotected. Indeed, the demand that juries be allowed to determine debt cases was raised repeatedly - though often subtly-in almost every state ratifying convention. For their part, federalists argued that eliminating juries in certain civil cases-most notably admiralty, debt and revenue cases-was essential to the nation's future commercial development.

\section{Pennsylvania}

In the Pennsylvania convention, the arguments over the supposed lack of a right to a jury trial and the reach of the federal courts' diversity and equity jurisdiction were closely tied together. Shortly after the convention began, James Wilson took the floor to defend the Constitution against the claim that it abolished the right to trial by jury. ${ }^{200}$ "It is very true," Wilson said, "that trial by jury is not mentioned in civil cases," but it "is very

198. U.S. CONST. art. $1, \S 10, \mathrm{cl} .1$.

199. This was because these two clauses were designed to put an end to the states' ability to pass "tender" laws and other debtor-friendly legislation. The scarcity of specie during the confederation caused many states to enact laws requiring creditors to accept the tender of state bills of credit in full payment of debts. States then proceeded to devalue these bills with repeated emissions of paper money. State legislatures also sought to protect debtors through the passage of "stay laws," prohibiting suits for debt or execution on judgments in debt cases. Tender and stay laws were attacked by commercial interests throughout the confederation period. The Contracts Clause was, therefore, designed to prevent states from passing laws altering the rights of creditors. The Tender Clause was designed to prevent states from requiring creditors to accept paper money in lieu of specie. See Stuart Bruchey, The Impact of Concern for the Security of Property Rights on the Legal System of the Early American Republic, 1980 WIS. L. REV. 1135, 1137-42 (describing concerns with tender and stay laws).

200. 2 ElLIOT'S DEBATES, supra note 40, at 450, 488. Wilson also defended Article III's grant of jurisdiction over diversity cases and suits against the states. Id. at 487-89, 491-93. 
improper to infer from hence that it was not meant to exist under this government." 201 Rather, Wilson noted, "[T] he manner of summoning jurors, their qualifications, of whom they should consist, and the course of their proceedings, are all different in different states." ${ }^{\text {"202 }}$ As a result, "it would have been impracticable, by any general regulation, to give satisfaction to all," because the convention "could not go into a particular detail of the manner that would have suited each." ${ }^{203}$ The convention was, therefore, forced to leave the matter to the Congress:

Where the people are represented, where the interest of government cannot be separate from that of the people,... the power of making regulations with respect to the mode of trial may certainly be placed in the legislature; for I apprehend that the legislature will not do wrong in an instance from which they can derive no advantage. ${ }^{204}$

More importantly, Wilson argued, "[B]y the Constitution of the different states, it will be found that no particular mode of trial by jury could be discovered that would suit them all." The task, he said, was best left to the judiciary, which would "make the regulations as agreeable to the habits and wishes of the particular states as possible. ${ }^{\text {205 }}$

In defending the Constitution's broad grant of jurisdiction to the federal courts, Wilson advanced the theory that the right to a jury trial in some civil cases had to be limited in order to protect the nation's economic future. Diversity and alienage jurisdiction were necessary, Wilson said, to prevent the states from frustrating the enforcement of debts through tender laws and instalment acts:

Is it not an important object to extend our manufactures and our commerce? This cannot be done, unless a proper security is provided for the regular discharge of contracts. This security cannot be obtained, unless we give the power of deciding upon those contracts to the general government. ${ }^{206}$

Wilson also suggested that juries were useful only when they were familiar with both parties. However, most of the cases falling within the federal courts' civil jurisdiction involved transactions which "extend beyond the bounds of any particular state," and which "depend either upon the law of nations ... or the general law of mercantile countries. ${ }^{207}$ As a result, he

201. Id. at 488 .

202. Id.

203. Id.

204. Id. at 488 .

205. 2 ELLIO'T'S DEBATES, supra note 40 , at 488.

206. Id. at 492.

207. Id. at 516 . 
said, "[I]t will not be pretended that [trial by jury] ought to be adopted" in such cases. ${ }^{208}$ Wilson concluded his argument by asserting that the Supreme Court's jurisdiction over fact was necessary to allow review of the decrees in admiralty matters, and he reminded his listeners of the difficulties caused for many American traders by the erroneous verdicts of state court juries in prize cases:

The jurisdiction as to fact may be thought improper; but those possessed of information on this head see that it is necessary. We find it essentially necessary from the ample experience we have had in the courts of admiralty with regard to captures. Those gentlemen who, during the late war, had their vessels retaken, know well what a poor chance they would have had when those vessels were taken in their states and tried by juries, and in what a situation they would have been if the Court of Appeals had not been possessed of authority to reconsider and set aside the verdicts of those juries. ${ }^{209}$

The antifederalists responded to Wilson's assertions with the charge that the Philadelphia Convention intended to subvert the rights of the people and introduce a new mode of proceeding. As proof of the Convention's grand design, they noted that "the trial by jury, which is the grand characteristic of the common law, is secured by the constitution, only in criminal cases. ${ }^{210}$ The antifederalists also pointed to Article III's grant of jurisdiction "both as to Law and Fact" for further proof, noting that:

[t] he only mode in which an appeal from law and fact can be established, is, by adopting the principles and practice of the civil law; unless the United States should be drawn into the absurdity of calling and swearing juries, merely for the purpose of contradicting their verdicts, which would render juries contemptible and worse than useless. ${ }^{211}$

Finally, they noted, the new federal courts would "decide on all cases of law and equity, which is a well known characteristic of the civil law."212 The fact that these same courts would also have jurisdiction over admiralty matters was proof beyond doubt of the Convention's duplicity; for such cases "are matters belonging exclusively to the civil law, in every nation in Christendom. ${ }^{\text {213 }}$ The mode of proceeding thus contemplated would impose

208. Id.

209. Id. at 493 .

210. The Address and Reasons of Dissent of the Minority of the Convention of the State of Pennsylvania to Their Constituents, (Dec. 18, 1787), reprinted in 3 ANTI-FEDERALIST, supra note 163 , at 159.

211. Id.

212. Id.

213. Id. at 160 . 
"monstrous expence and inconveniences" that will "prove intolerable to the people of this country." 214 The eventual result, the antifederalists argued, would be "the loss of the invaluable right of trial by an unbiased jury, so dear to every friend of liberty." 15

The antifederalists also pointed to the dangers for poor citizens posed by the federal courts' equity jurisdiction. They feared that "rich and wealthy suitors would eagerly lay hold of the infinite mazes, perplexities and delays, which a court of chancery ... would furnish him with, and thus the poor man being plunged in the bottomless pit of legal discussion, would drop his demand in despair. ${ }^{216}$ Chancery jurisdiction was particularly controversial in Pennsylvania where equity cases were tried in the common-law courts using juries. Allowing federal courts to try equity matters without juries opened the door to numerous ejectment actions and title claims by land speculators with large investments in Pennsylvania's western lands. In the antifederalists' view, poor farmers stood to be the losers if the wealthy were given a new device for asserting their claims. ${ }^{217}$

Pennsylvania's antifederalists insisted that the Constitution needed to be altered to limit the power of the national government. Consequently, they put forward a series of resolutions designed to ameliorate what they regarded as the consolidating tendencies of the Constitution. They urged that a bill of rights specifically enumerating the liberties of the people be included in the Constitution to prevent oppression by the national government. Among the liberties to be secured were the "unequivocal establishment of the writ of habeas corpus, jury trial in criminal and civil cases, by an impartial jury of the vicinage or county, with the common law proceedings, for the safety of the accused in criminal prosecutions; and the liberty of the press, that scourge of tyrants." ${ }^{218}$ The resolutions thus largely formed a draft bill of rights modeled along the lines of that contained in the Pennsylvania Constitution of $1776 .{ }^{219}$ The convention's federalist majority ensured that all these proposals were quickly rejected, however, and the constitution was ratified on December $12,1787 .^{220}$

214. Id.

215. The Address and Reasons of Dissent of the Majority of the Convention to their Constituents (Dec. 18, 1787), reprinted in 3 ANTI-FEDERALIST, supra note 163, at 157.

216. $\quad l d$.

217. Id. at 158 .

218. Id. at 157 .

219. The dissenters also proposed alterations to the jurisdiction of the federal courts. They suggested limiting federal court jurisdiction to cases involving ambassadors, admiralty matters, cases where the United States was a party, suits between States, and between a State and citizens of other States or a foreign country. The courts' criminal jurisdiction would be limited to such crimes as were expressly enumerated in the Constitution. The idea was to prevent the federal courts from having the power to affect individuals directly. Id.

220. Minutes OF THE CONVENTION OF PENnsylvania, Which COMMENCEd AT Philadelphia, on Tuesday, the Twentieth Day of November, One Thousand Seven 
The arguments of Pennsylvania's antifederalists became models for supporters of the constitution elsewhere, as antifederalists in other states took up the claim that the Constitution was defective without a bill of rights. The inability of the federalists to adequately defend the Constitution without concrete protections for individual rights required a shift in strategy. In order to obtain ratification by the other state conventions, the federalists were eventually required to admit the necessity of amendments containing explicit protections for individual rights.

\section{Massachusetts}

New England was to be the next battleground. ${ }^{221}$ A great part of the debate in Massachusetts centered on the question of whether the Constitution ought to include a bill of rights. The antifederalists argued that the Constitution was defective because it failed to protect the right to trial by jury. While much of the discussion focused on the lack of appropriate protections for juries in criminal cases, several speakers apparently argued that the omission of any mention of a right to jury trial in civil causes risked resurrecting all the same dangers and problems created by the colonial viceadmiralty courts' jurisdiction over trade and revenue matters. Thomas Dawes attempted to rebut these charges by stating that the allusion to the vice-admiralty courts was inapposite since those cases concerned criminal, not civil, cases. ${ }^{222}$ Dawes was wrong on this point, however. Perhaps taking his lead from Pennsylvania's James Wilson, Christopher Gore responded to these claims by asserting that the rules for the use of juries in the several states were so diverse that the framers could not have selected any one without offending some state. The best course of action therefore, was to leave it to the Congress to determine the procedures for the use and selection of juries when the time came to establish the inferior courts. ${ }^{223}$ Supporters of the Constitution also attempted to answer the complaint that the power to review fact and law would give the Supreme Court the power to review the findings of a jury. Thomas Dawes advanced a somewhat novel defense, arguing that the use of the word "court" in the Constitution does not exclude the use of a jury to try facts. After all, he asked, "[W] in common language, talk of a trial at the Court of Common Pleas, or the

HUNdRed AND EIGHTY SEvEN, FOR THE PURPOSE OF TAKING INTO CONSIDERATION OF THE CONSTITUTION FRAMED BY THE LATE FEDERAL CONVENTION FOR THE UNITED STATES OF AMERICA 12-13 (1787). The federalists had a clear majority in the Pennsylvania convention. The vote tallies usually reveal a $46-23$ margin in favor of the federalist position.

221. Six days after Pennsylvania's convention adjourned, New Jersey ratified the Constitution by unanimous vote, leaving the mid-Atlantic states firmly in the federalist camp. Delaware had ratified a few days before Pennsylvania, on December 7, 1787. New Jersey ratified on December 18, 1787. 1 ELLIOT'S DEBATES, supra note 40, at 319, 320.

222. 2 id. at $113-14$.

223. Id. at 112 . 
Supreme Judicial Court, do they not include all the branches and members of such court-the jurors as well as the judges? They certainly do, whether they mention the jurors expressly or not. ${ }^{224}$

This debate helped highlight the concern that, without a bill of rights, the Constitution lacked basic protections for individual liberty. Massachusetts eventually ratified the Constitution, but only after passing a list of "recommendatory" amendments, ${ }^{225}$ three of which consisted of revisions to the judicial power. These included specific guarantees for jury trials in civil cases, a jurisdictional amount on diversity cases, and a requirement that no person be tried for serious offenses unless he first be indicted by a grand jury. ${ }^{226}$

\section{South Carolina}

Much of the debate in South Carolina took place in the legislature as it was deciding whether to call a ratifying convention. ${ }^{227}$ As they had elsewhere, antifederalists questioned the absence of provisions granting jury trials in civil cases. ${ }^{228}$ In so doing, they made a direct connection between the right to jury trial and the need to protect debtors. ${ }^{229}$ Somewhat surprisingly, however, South Carolina's federalists did not seem to feel the need to rely on sophistry to defend the Constitution's apparent failure to include provisions guaranteeing the right to trial by jury. Indeed, unlike those who claimed that the Convention simply found it too difficult to set forth a general rule, South Carolina's federalists practically admitted that the Convention intended to limit the right to jury trial-at least in some civil cases, particularly admiralty and debt actions. Robert Barnwell answered the

224. Id. at 113. Alexander Hamilton put forth a similar argument in The Federalist No. 83.

225. The lack of a bill of rights was a real concern to members of the Massachusetts Ratifying Convention. However, many also feared that insisiting on amendments as a condition of ratification would doom the chances of the Constitution being ratifyied by all 13 states, since each state would likely insist on different amendments. To forestall the possibility of a conditional ratification, the convention's president, John Hancock, proposed that the convention give its assent to the Constitution but recommended that certain alterations be made at the earliest opportunity. See 1 MASS. CONVENTION J. (1788), in 6 DocuMENTARY HistoRY OF THE RATIFICATION OF THE CONSTITUTION 1380-81 (John P. Kaminski \& Caspare J. Saladino eds., 2000).

226. The convention voted to ratify the Constitution on February 7, 1788 by a vote of 187 in favor and 168 opposed. 2 Ellior's DEBATES, supra note 40, at 181. There was great disagreement over whether the convention was authorized to propose amendments, and some delegates wanted to make the ratification conditional on the inclusion of the proposed revisions. A compromise was finally reached requiring Massachusetts's representatives in the proposed federal Congress to "exert all their influence, and use all reasonable and legal methods, to obtain a ratification of said alterations and provisions." Id. at 178.

227. The assembly debate lasted from January 16 to January $19,1788.4 \mathrm{id}$. at 253-342.

228. Id. at 290.

229. Id. at 289-90 (statement of Rawlins Lowndes, S.C.) (linking emission and tender laws to debt relief). 
antifederalists' objections by pointing out the practical difficulties of using juries in diversity cases, and asserted that it might be appropriate to limit the right to a jury trial. What would happen, he asked, if a citizen of South Carolina was forced to sue a citizen of Georgia in the Georgia courts? "Why, the citizen of this state must rest his cause upon the jury of his opponent's vicinage, where, unknown and unrelated, he stands a very poor chance for justice against one whose neighbors, whose friends and relations, compose the greater part of his judges. ${ }^{230}$ Would this hypothetical Carolinian not prefer to put his case to "an impartial and responsible individual" rather than "a jury with whom he is unacquainted[?]" General Charles Coatsworth Pinckney echoed this response, asking, "In a dispute between a citizen of Carolina and a citizen of Georgia, if a jury was to try the case, from which state are they to be drawn?" ${ }^{232}$ Pinckney also reminded his listeners of the difficulties created by the use of juries in prize cases during the Revolution. ${ }^{233}$ Trial by jury was, therefore, expressly preserved in criminal cases, but Congress was left to determine the circumstances under which juries would be used in civil trials. ${ }^{234}$ In any event, concerns about the right to a jury trial were not enough to prevent South Carolina's convention from ratifying the Constitution by a large margin. ${ }^{235}$

\section{North Carolina}

In North Carolina, land claims dominated the debate over the lack of a civil jury trial provision. The fear that federal courts would be able to try land cases without a jury raised the spectre of poor farmers being ousted from their lands by out-of-state speculators-or worse, former tories. James M'Dowall went further and complained that even if a jury were empaneled in the first instance, a wealthy litigant would be able to use the Supreme Court's appellate jurisdiction over law and fact to win out in the end,

230. Id. at 295.

231. 4 ELLIOT'S DEBATES, supra note 40 , at 295.

232. Id. at 307 .

233. Id:

[O]n the first establishment of the admiralty jurisdiction, Congress passed an ordinance requiring all causes of capture to be decided by juries: this was contrary to the practice of all nations, and we knew it; but still an attachment to a trial by jury induced the experiment. What was the consequence? The property of our friends was, at times, condemned indiscriminately with the property of our enemies, and the property of our citizens on one state by the juries of another. Some of our citizens have severely felt these inconveniences. Citizens of other states and other powers experienced similar misfortunes from this mode of trial. It was, therefore, by universal consent and approbation, laid aside in cases of capture.

234. Id. at 307-08.

235. See id. at 341 (noting that the Convention ratified the Constitution by vote of 149 in favor and 73 against). 
especially when a poor man was unable to defend the appeal in the far-off capital:

We know that the trial by jury of the vicinage is one of the greatest securities for property. If causes are to be decided at such a great distance, the poor will be oppressed; in land affairs, particularly, the wealthy suitor will prevail. A poor man, who has a just claim on a piece of land, has not substance to stand it. Can it be supposed that any man, of common circumstances, can stand the expense and trouble of going from Georgia to Philadelphia, there to have a suit tried? And can it be justly determined without the benefit of a trial by jury? These are things which have justly alarmed the people. ${ }^{236}$

Richard Spaight answered M'Dowall's objection, but ignored its substance. The most Spaight could offer in response was the oft-heard refrain that it was simply "impossible to make any one uniform regulation for all the states. ${ }^{237}$

Concerns about individual liberty convinced many in the North Carolina convention that the Constitution required substantial amendment. North Carolina thus failed to ratify the Constitution until 1790.

\section{Virginia}

Eight states had ratified the Constitution by the time the Virginia convention met in June 1788. Antifederalists did not, therefore, have the luxury of arguing for the status quo. A single ratification from the North would mean that the old order was no more. As Governor Edmund Randolph noted on the last day of the debate, the assent of eight states reduced Virginia's "deliberations to the single question of Union or no Union." 238

George Mason proved to be Virginia's most vigorous opponent of an extensive federal judiciary. Echoing comments he had already made in the press, ${ }^{239}$ Mason argued that the federal courts' jurisdiction was so broad that it would leave nothing to those of the states. ${ }^{240} \mathrm{He}$ also touched on two subjects guaranteed to keep the interest of Virginia's planters: debts and land claims. Mason argued that the federal courts' diversity jurisdiction would mean the oppression of local farmers at the hands of British

236. 4 ELLIOT'S DEBATES, supra note 40 , at 143.

237. Id. at 144 .

238. Id. at 652 .

239. See George Mason, Objections to the Constitution of Government Formed by the Convention, VA. J., Nov. 22, 1787, reprinted in 2 ANTI-FEDERALIST, supra note 163, at 12 (arguing that the judiciary of the United States would destroy those of the states).

240. 3 ELLIOT'S DEBATES, supra note 40 , at 521-22, 525 . 
creditors. ${ }^{241}$ After all, by 1787, Virginia farmers were indebted to British merchants in an amount exceeding $£ 2$ million. ${ }^{242}$ Virginia's courts had long been closed to British creditors seeking to recover pre-war debts, ${ }^{243}$ so the possibility that Virginians might be subject to federal jurisdiction could not have been a welcome one. Mason also noted that federal courts would have jurisdiction over land claims as well, thus leaving many Virginians uncertain as to whether they had proper title to lands on which they had made their living for some years. ${ }^{244}$ Mason even went so far as to raise the specter that a federal court might extinguish the titles of Virginians living on lands formerly belonging to Lord Fairfax. ${ }^{245}$

Mason also challenged the argument that trial by jury was preserved in the new Constitution. Like other antifederalists before him, Mason worried that giving the Supreme Court appellate jurisdiction over both law and fact would result in appeals being decided "according to the Roman law"-which is to say without juries. ${ }^{246}$ Far more troubling, however, was the idea that Congress should be left to determine the circumstances under which jury trials would be available in civil cases. Ever the republican, Mason warned against leaving the protection of individual rights to a legislative body. "We are told," he said, "that we are to part with that trial by jury which our ancestors secured their lives and property with, and we are to build castles in the air, and substitute visionary modes of decision for that noble palladium." ${ }^{247}$ Trial by jury was a right "which our ancestors secured their lives and property with;" it was "essential[] to the preservation of liberty" and could not be alienated by a free people without inviting the most dire consequences. ${ }^{248}$ Mason recalled the long history of the jury as a bulwark against oppression and warned his listeners of the dangers of leaving rules concerning juries to Congress's discretion:

Why do we love this trial by jury? Because it prevents the hand of oppression from cutting you off. They may call any thing rebellion, and deprive you of a fair trial by an impartial jury of your neighbours.... [S]hall Americans give up that which nothing could induce the English people to relinquish? ${ }^{249}$

For Mason and others, therefore, the Framers' intent was clear. The

\footnotetext{
241. Id. at 526 .

242. See supra note 104 (detailing the amount of debt owed by various colonies to British commercial interests).

243. See text accompanying notes 121-26 (describing Virginia's opposition to permitting recovery of British debts).

244. 3 ELLIOT'S DEBATES, supra note 40 , at 530.

245. Id at 528-29.

246. Id at 546 .

247. Id. at 544 .

248. Id.

249. 3 ELLIOT'S DEBATES, supra note 40 , at 545 .
} 
Constitution "was not intended to have jury trials at all; because, difficult as it was, the name was known, and it might have been inserted."250

James Madison responded to these objections by pointing out that the vast majority of lawsuits would still be brought in state, rather than federal, courts. ${ }^{251} \mathrm{He}$ also defended the courts' federal question jurisdiction, arguing that the judicial power should be coextensive with that of the national government as a whole. ${ }^{252}$ Leaving state courts to interpret or enforce acts of Congress would impede the ability of the federal government to effect national aims. ${ }^{253}$ In addition, he said, intercourse with foreign nations requires that the decisions of courts be uniform. ${ }^{254}$ This could only be done by giving the federal courts jurisdiction over cases involving treaties, ambassadors or foreign ministers. ${ }^{255}$ Diversity jurisdiction was made necessary because a "citizen of another state might not chance to get justice in a state court, and at all events he might think himself injured. ${ }^{256}$ No doubt referring to the numerous pending claims for debt, Madison noted "what tardy, and even defective, administration of justice has happened in some states." ${ }^{257}$ For Madison, then, concerns that the federal court would be an instrument of oppression were overblown. It made little sense, in his view, to assume that the judges of the national courts would care less for concerns of the people than those of the states. Madison claimed that "the general government will do what is for the interest of the United States; because they have no substantial reason or inducement to violate their duty, nor are they warranted by this part of the plan to commit the oppressions" dreaded by the Constitution's opponents. ${ }^{258}$ The aim of the judiciary article was "to prevent all occasions of having disputes with foreign powers, to prevent disputes between different states, and remedy partial decisions. I believe this to be wise and salutary." ${ }^{259}$

For his part, Edmund Pendleton disputed Mason's charge that the Constitutional Convention intended to eliminate the right to trial by jury. He assured the delegates that he "never could see such intention, or any tendency towards it" while in Philadelphia, nor had he "heard any arguments of that kind used in favor of the Constitution." ${ }^{260}$ As for worries that Congress might use its legislative powers to eliminate jury trials in

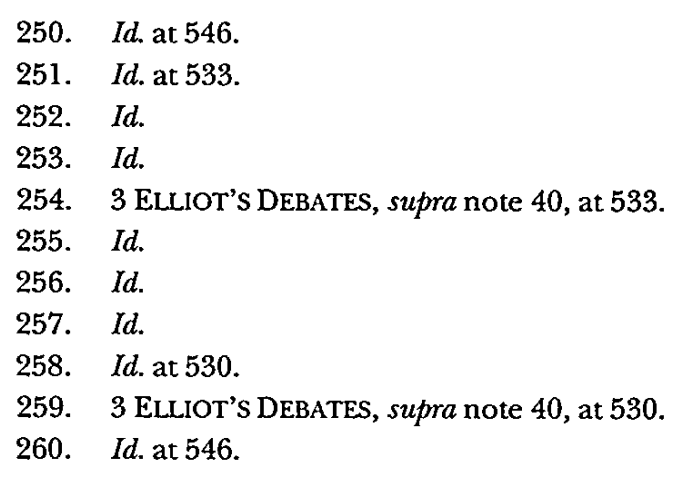


federal courts, Pendleton asserted that the people could reasonably leave the business to "our agents and rulers." America's revolutionary fervor was, he argued, the best defense against government oppression. ${ }^{262}$ "So great is the spirit of America," Pendleton proclaimed, "that it was found sufficient to oppose the greatest power in the world." ${ }^{263}$ Would not that same spirit, then, "protect us against any danger from our own representatives?"264

On June 21, 1788, word reached Virginia that New Hampshire had ratified the Constitution. The tone of the debate changed rapidly as a result; no longer was it a question of union or confederation. ${ }^{265}$ It was instead one of whether Virginia would remain outside the union formed by the other states. ${ }^{266}$ Virginia's isolation in such a case would not only be political, but geographic as well, because the states to its north and south-with the exception of North Carolina-had already ratified. As a result, Virginia narrowly voted to ratify the Constitution on June 25, 1788, but only after putting forward a proposed bill of rights consisting of twenty articles in addition to twenty other amendments to the Constitution itself. ${ }^{267}$

\section{JURIES AND THE FIRST JUDICIARYACT}

When the first Congress met in the spring of 1789, a considerable segment of the population still had not been reconciled to the new frame of government. Many continued to believe that the Constitution would eventually result in the annihilation of the state governments and the extermination of liberty. Although the Constitution had been ratified by the requisite number of states, many had ratified only on the closest of margins. Indeed, in more than a few states, ratification had been made possible only by federalist promises to amend the Constitution immediately after it came into effect. Meanwhile, the disaffected continued to call for a second constitutional convention. In addition, two states, North Carolina and Rhode Island, still refused to ratify and remained outside the union. Congress thus faced a daunting challenge. It had to establish the new nation on a firm footing without further alienating the antifederalist segment of the population. Congress also had to show that the new government would be an effective, but benign, influence. Among the first tasks confronting the new Congress, therefore, was the creation of a national judiciary.

The shape of the federal courts was of great importance to the new Republic. Thus, while the House took up a revenue bill, the Senate

261. Id. at 550 .

262. Id.

263. Id. at 550 .

264. 3 Eluiot's DeBATES, supra note 40 , at 550 . Pendleton was followed by John Marshall, who also spoke at length on the subject of juries. Id. at 551-62.

265. Id. at 652-53.

266. Id.

267. Id. at 657-59. 
appointed a committee to establish a national judiciary. The judiciary committee's deliberations were watched very closely by those both in and out of Congress. Although the committee's debates were kept secret, it is clear that during the course of their work, the members were careful to consider the objections made to the Constitution in general, and to the judiciary article in particular. They took special note of the complaints about diversity and alienage jurisdiction, jury trials in civil cases, and the appellate jurisdiction of the Supreme Court. These issues were, after all, immensely important, not only as a matter of political ideology, but also because committee action on each would have important economic consequences. After all, the federal courts were considered an essential part of the government regime. Not only would they provide a forum for the trial of crimes against the government, but they were destined to serve other significant national interests. They were designed to be the primary means by which the federal government could enforce its revenue laws and were expected to take jurisdiction over cases involving important federal questions. Even more ominous for some, however, was the fact that the courts would provide a forum for the resolution of the British debt claims.

As a result, the members of the judiciary committee were keenly aware that the choices they would make in creating the courts would have significant-and potentially explosive-consequences. Accordingly, they were forced to weigh their options carefully and strike an appropriate balance between vigor and conciliation. Most of the members of the committee seem to have recognized that giving the courts all of the jurisdiction conferred by Article III would not only antagonize the antifederalists, but might also endanger the chances for ratification in North Carolina and Rhode Island, two states that still remained outside the union. Moreover, the controversy over the perceived failure of the Constitution to provide a right to trial by jury was not lost on the drafters of the Judiciary Act. Their efforts culminated in several provisions designed to ensure that jury trials would be available in a wide range of civil and criminal actions. They also decided to limit the jurisdiction of the courts in significant ways. In so doing, the drafters of the first judiciary act traded away maximum efficiency in an effort to neutralize the concerns of those who still had reservations about the new constitutional scheme.

\section{A. CREATING THE COURTS}

Aside from a few general provisions, the Constitution gave the first Congress very little textual guidance as to how the judiciary should be structured. ${ }^{268}$ This was mainly because the delegates at Philadelphia could

268. As noted above, the Constitution provided only the barest outlines of a judicial system.

The judicial power of the United States was to be vested in "one Supreme Court" and in "such inferior courts as the Congress may from time to time ordain and 
not agree among themselves on whether to establish an extensive national judiciary. Although most members of Congress did not think Article III required the creation of lower federal courts, the judiciary committee determined rather early on that such courts were necessary to effect several important governmental aims.

The committee's final draft provided for a three-tiered judicial system. The apex of the structure was the Supreme Court, which, in addition to the original jurisdiction conferred on it by Article III, would have appellate jurisdiction over cases brought from both the lower federal courts as well as the courts of the states. ${ }^{269}$ The bill then divided the United States into thirteen districts, and a district court was established in each. ${ }^{270}$ The district courts had original jurisdiction over minor crimes, admiralty cases, and suits at common law brought by the United States in which the amount in controversy was over one hundred dollars. ${ }^{271}$ The Act also divided the United States into three circuits, and a circuit court was to be held twice each year in every district in the circuit. ${ }^{272}$ The circuit courts were to be composed of two justices of the Supreme Court and the judge of the district in which the circuit court was sitting at the time. ${ }^{273}$ These courts had original jurisdiction over diversity and alienage cases in which the amount in controversy was over five hundred dollars, as well as suits at common law brought by the United States and involving a similar amount. The criminal jurisdiction of the circuit courts included "all crimes and offences cognizable under the authority of the United States." ${ }^{274}$ The circuit courts

establish." The judges were to "hold their offices during good behavior, " and their salaries could not be "diminished during their continuance in office." The judicial power was defined to extend to [a wide array of cases] ... "with such exceptions, and under such regulation, as the Congress shall make."

David P. Currie, The Constitution in Congress: The Federalist Period 1789-1801, at 47 (1997) (citing U.S. CONST. art. III).

269. Judiciary Act of $1789, \S 13$, I Stat. 73, 80 (1789).

270. Each of the eleven states comprised a district; and separate districts were created for Maine, which was then a part of Massachusetts, and Kentucky, which was still a part of Virginia. Id. at $\S 2,1$ Stat. at 73. Because Rhode Island and North Carolina had not yet ratified the Constitution, the Judiciary Act did not make any provision for them. The district courts were to convene four times each year at stated intervals. $I d$. at $\$ 3,1$ Stat. at 73-74.

271. Id. at $\S 9,1$ Stat. at $76-77$.

272. The states of New Hampshire, Massachusetts, Connecticut, and New York comprised the Eastern Circuit. The Middle Circuit consisted of Pennsylvania, New Jersey, Delaware, Maryland, and Virginia. South Carolina and Georgia formed the Southern Circuit. Id. at \$ 4, 1 Stat. at 74-75. Maine and Kentucky were not made part of any circuit. The district court in each was to exercise the powers of a circuit court, except with respect to the power to hear appeals and issue writs of error. Appeals from Maine were taken to the circuit court for the Eastern Circuit. Appeals from Kentucky were taken directly to the Supreme Court. Id. at $\$ 10,1$ Stat at $77-78$.

273. Id. at $\$ \S 4-5,1$ Stat. at 7475 .

274. Judiciary Act of $1789, \S 11,1$ Stat. 73, $78-79$ (1789). 
also had appellate jurisdiction over cases from the district courts, provided certain jurisdictional amounts were met. ${ }^{275}$

When it came to allocating the civil jurisdiction among the several courts, the judiciary committee obviously paid careful attention to the concerns about federal courts raised by antifederalists during the course of the ratification debates. Giving the circuit courts jurisdiction over cases brought by the United States allowed the federal government to proceed in its own courts to recover fines and forfeitures resulting from violations of its laws and to recover damages from breaches of contracts made with government suppliers. The judiciary committee clearly designed the diversity and alienage provisions to allay concerns that British creditors would flood the new federal courts with actions for debt. While the continuing refusal of many state courts to entertain such cases made the resolution of British debt claims of paramount importance to the drafters of the Judiciary Act, there was a great deal of concern that small debtors not be subjected to vexatious litigation in courts distant from their homes. The judiciary bill addressed these concerns by vesting diversity jurisdiction exclusively in the circuit court. The amount in controversy limitation ensured that cases brought in federal court to recover debts would be limited to controversies of substance. ${ }^{276}$ The bill also prevented the use of assignments to avoid the diversity limitations. An assignee could not bring suit against a citizen of the United States on a promissory note or chose in action unless the action might have been commenced in the district without the assignment. ${ }^{277}$ This rule prevented making assignments merely for the purpose of creating diversity between the parties.

The judiciary committee designed the circuit court to serve as the primary trial court. The district court, on the other hand, was intended to function as "an American exchequer court." It did not have either diversity or equity jurisdiction. Instead, its civil jurisdiction generally concerned revenue and trade matters, although it had a modest alienage jurisdiction that allowed an alien to sue "for tort only in violation of the law of nations." 278 The district courts were thus destined to serve as the primary forum for admiralty cases, as well as for trials for seizures under the trade and revenue laws. They were vital, therefore, to ensuring the stability of the new nation's revenue.

275. Id. at $\$ 21,1$ Stat. at 83 .

276. Charles Warren surmises that the jurisdictional amount of five hundred dollars was intended to defeat any claims for quit rents due the assignees of Lord Fairfax. Charles Warren, New Light on the History of the Federal Judiciary Act of 1789, 37 HARV. L. REV. 49, 78 (1923).

277. Judiciary Act of $1789 \$ 11$.

278. Id. at $\$ 9,1$ Stat. at 77. Tort cases, after all, were not among the categories of cases that so aroused indignation about foreign plaintiffs. 


\section{B. TRIAL BY JURY AND APPEALS OF FACT}

In crafting the judiciary bill, the committee addressed the antifederalists' concerns about the lack of a civil jury trial guarantee in several ways. The bill began by providing that an action at law against a citizen brought by virtue of the Supreme Court's original jurisdiction should be tried by jury. ${ }^{279}$ The Judiciary Act further strengthened the jury trial right by restricting the Supreme Court's power to hear appeals to civil actions and suits in equity. The Court had no jurisdiction over criminal appeals, and appeals in civil cases were subject to a jurisdictional amount. ${ }^{280}$

In the circuit and district courts, the judiciary bill provided that the trial of all questions of fact in actions brought at law would be by jury. ${ }^{281}$ The qualifications and mode of selecting jurors were to conform as much as possible to that used in the courts of the state wherein the trial was held. ${ }^{282}$ These provisions did not satisfy everyone, however. For, while the judiciary bill provided basic protections for jury trial in cases brought at common law, senators from states with more generous jury trial provisions were concerned with what they believed were holes in the bill-holes which would allow crafty lawyers and overreaching judges to extend the scope of admiralty or equity so as to deprive litigants of their right to a jury trial. ${ }^{283}$ Among the most vocal of the bill's critics on this issue was Pennsylvania Senator William Maclay, whose concerns reflected his state's long tradition of using juries to try a wide variety of cases, whether brought at law, in equity, or in admiralty. ${ }^{284}$ Maclay's concern with the judiciary bill was that it apparently only protected the right to jury trial in common-law cases. The bill did not mention juries in admiralty and equity cases, and thus appeared to limit the right to jury trial already available in many states. In the end, however, Maclay was unsuccessful in convincing the Senate to expand the right to trial by jury to admiralty or equity cases. Maclay's complaint in this regard casts substantial doubt on Professor Amar's theory of dynamic nonconformity. It seems that Maclay and most others in the Senate understood that state rules would not determine when juries would be available in federal courts. On

279. Id. at $\$ 13,1$ Stat. at 80 . The interesting point about this provision, however, was its limitation to cases brought against citizens. Foreigners were denied the same right. The jury trial provision was interpreted liberally, however. In Georgia v, Brailsford, 3 U.S. (3 Dall.) 1, 3-4 (1794), the Supreme Court ordered a jury trial even though only one of the four defendants was a citizen.

280. Judiciary Act of $1789 \S 22$.

281. Id. at $\$ 9,1$ Stat. at 77 .

282. Id. at $\$ 29,1$ Stat at 88 .

283. Alexander Hamilton surveyed varying jury trial practice in the several states in The Federalist No. 83.

284. See, e.g., Act of May 13, 1968, I Pa. Stat. 227, 229 (1698), in THE STATUTES AT LARGE OF PENNSYlVANIA IN THE TIMES OF William PENN: 1680-1700 (Gail McKinght Beckman ed., 1976) (preventing frauds and regulating trade abuses); An Act for Establishing Courts of Judicature, in ChARTERS AND LAWS OF PENNSYLVANIA, supra note 67, at 311. 
the contrary, Maclay's attack on the judiciary bill indicates that most senators understood that federal, rather than state law would dictate the availability of jury trials. ${ }^{285}$

The drafters also limited the opportunity for appeals to the Supreme Court because of antifederalist complaints that wealthy litigants would be able to force a poorer opponent to travel many hundreds of miles to defend their cases. ${ }^{286}$ As a result, the bill allowed Supreme Court review in suits at law and equity that had been brought in a circuit court "by original process, or removed there from courts of the several States, or removed there by appeal from a district court," provided that the amount in controversy exceeded the sum of $\$ 2000 .^{287}$ However, suits appealed to the circuit court from the district courts by writ of error were not appealable to the Supreme Court. ${ }^{288}$ There was, in other words, to be one opportunity for review in most cases. The bill provided an exception which permitted review in the Supreme Court of admiralty cases after an appeal to the circuit court, provided that the litigants satisfied the requisite amount in controversy. ${ }^{289}$

\section{ADMIRALTY, EQUTTY, AND THE COMMON LAW}

While there was general agreement that admiralty jurisdiction must be vested in some federal court, many in Congress remained concerned about the relationship between admiralty jurisdiction and the right to trial by jury. The judiciary bill sought to protect the federal interest in admiralty uniformity while permitting jury trials in some admiralty cases by allowing certain common law claims to proceed in state courts with juries even though they might have a maritime connection. The result was the inclusion of what has since become known as the "Savings Clause," which provided that the district courts would have "exclusive original cognizance" of all civil causes of admiralty and maritime jurisdiction, "saving to suitors, in all cases, the right of a common law remedy, where the common law is competent to give it.",900

285. See supra notes $35-43$ and accompanying text (discussing Amar's theory of dynamic nonconformity).

286. See, e.g., Letter from Richard Henry Lee to Governor Edmund Randolph (Dec. 6, 1787), reprinted in 5 ANTI-FEDERALIST, supra note 163, at 112, 115:

[I]f [Congress does] not regulate the right of appeal reasonably, the people will be exposed to endless oppression, and the necessity of submitting in multitudes of cases, to pay unjust demands, rather than follow suitors, through great expence, to far distant tribunals, and to be determined upon there, as it may be, without a jury.

287. Judiciary Act of $1789 \S 22$.

288. This anomaly was not corrected until 1840. See Act of July 4, 1840, 5 Stat. 392, 393 (1840).

289. This was, perhaps, owing to the fact that the circuit court might reconsider facts in admiralty cases tried in the district court. An appeal to the Supreme Court would, therefore, be the first opportunity to appeal after the final determination of the facts. Judiciary Act of $1789 \S$ 21.

290. Id. at $\$ 9,1$ Stat. at 77 (emphasis added). 
The Savings Clause has become the "source of most of the federalism problems that have arisen in admiralty," generating a long line of cases attempting to discern what exactly was meant by the term "common law remedy. ${ }^{299}$ At the same time, however, the Clause succeeded in satisfying those who feared the extensive powers of courts vested with admiralty jurisdiction by preserving the right to jury trial in state courts. After all, while most senators recognized the need to ensure that federal courts had primary responsibility for prize and piracy cases, private litigation was another matter altogether. Congress settled upon the Savings Clause as the means most likely to satisfy legitimate foreign relations concerns while still preserving long-established jury trial rights. Many states remained firmly attached to the widespread use of juries and continued to use juries to try commercial admiralty cases. As a result, some in Congress feared that vesting federal courts with "exclusive" admiralty jurisdiction would eliminate the right to trial by jury in private law actions, which had less potential to implicate the rights of foreigners. ${ }^{292}$ Allowing a common-law remedy in these kinds of cases effectively meant that a plaintiff had several options when deciding where to bring suit. A plaintiff desiring a federal forum might sue in the district court in admiralty or bring an action in diversity in the circuit court, provided, of course, that the jurisdictional amount of $\$ 500$ was satisfied. ${ }^{293}$ He might also proceed at law in one of the state courts. ${ }^{294}$ The Savings Clause thus became simply one more compromise between the proponents of a strong national judiciary and those who sought broad limitations on the powers of the federal government.

Nevertheless, in what must certainly be regarded as one of the most ironic twists of the founding era, the Judiciary Act provided that the category of "civil causes of admiralty and maritime jurisdiction" was to include "all seizures under the laws of impost, navigation or trade of the United States." 295 This clause gave federal district courts sitting in admiralty the power to try all seizures under the revenue laws. This was the case notwithstanding all of the vitriol directed against precisely the same jurisdiction when vested in the colonial vice-admiralty courts. It appears that, once free from British control, American legislators forgot most of the rhetoric about the evils of trying trade cases in admiralty. ${ }^{296}$ This is no doubt

291. DAVID W. ROBERTSON, ADMIRALTY AND FEDERALISM 18-19 (1970).

292. The rather odd result, therefore, is that the Judiciary Act gives district courts "exclusive original cognizance ${ }^{n}$ of admiralty matters without really meaning it.

293. Judiciary Act of $1789 \S 12$.

294. Cf. Camberling v. McCall, 2 U.S. 280, 281, 2 Dall. 245 (Pa. 1797) (marine insurance); Waters v. Collot, 2 U.S. 247, 248, 2 Dall. 214 (Pa. 1796) (wrongful arrest); Thurston v. Koch, 4 U.S. 348, 348, 4 Dall. 301 (G.C.D. Pa. 1800) (marine insurance); Pollock v. Donaldson, 3 U.S. 510, 511, 3 Dall. 403 (C.C.D. Pa. 1799) (insurance).

295. Judiciary Act of $1789 \S 9$.

296. It seems clear that the erstwhile revolutionaries lost some of their suspicions of the 
because the drafters of the Judiciary Act recognized the desirability of having some way to protect the new nation's revenue. ${ }^{297}$ Indeed, one of the very first bills signed into law provided for the seizure and forfeiture of vessels involved in smuggling, and enforcement became an immediate concern. ${ }^{298}$ Congress clearly thought that some departure from the principle of trial by jury was necessary if the new union was to survive. ${ }^{299}$ The drafters of the Judiciary Act did make a concession to the earlier controversy, however, by providing that the trial of seizures made on land and of "all suits for penalties and forfeitures incurred under the laws of the United States" would be had on the law side of the district court. ${ }^{300}$ As a result, land-based seizures were to be tried with juries. ${ }^{301}$

admiralty once the judges ceased to be Crown appointees. As a result, no longer were the admiralty courts prerogative courts, employing foreign procedures and enforcing onerous trade regulations. Rather, they were now representative of the people at large; they were a truly American institution. The Supreme Court explained the distinction some years later:

[T]here is a wide difference between an English admiralty judge and one appointed under the Constitution of the United States. The reasons for entertaining a jealousy against the former do not apply to the latter. In the United States, admiralty judges, as well as common law judges, are appointed by and responsible to the people, in some form or other. [Likewise,] if our American ancestors were jealous of the jurisdiction of the vice-admiralty courts of the colonies, the reason for that jealousy ceased when we became an independent people. A vice-admiralty judge of the colonies was the representative of the crown; the people of the colonies had no voice nor participation in his proceedings. It was a foreign tribunal .... But when the people of the United States came to frame a government for themselves, and to establish a judiciary which should be ultimately responsible to them ... the Convention and Congress understood their change of position.

N. J. Steam Navigation Co. v. Merchant's Bank, 47 U.S. (6 How.) 343, 374-75 (1845).

297. Fisher Ames argued for the importance of a steady revenue stream, noting " $[t]$ hat money is power, [and] a permanent revenue is permanent power." Letter from Fisher Ames to George Richards Minot (May 16, 1789), in 1 WORKS OF FISHER AMEs 39 (Seth Ames ed., 1854) (1809).

298. Act of Sept. 1, 1789, ch. 11, 1 Stat. 55 (1789).

299. Years later, Justice Chase recalled that "[ $t]$ he reason of the legislature for putting seizures of this kind on the admiralty side of the court was, the great danger to the revenue, if such cases should be left to the caprice of juries." The Betsey \& The Charlotte, 8 U.S. (4 Cranch) 442,446 (1808). A long line of Supreme Court cases has since firmly established that seizures made on navigable waters do not require trial by jury. See, e.g., LaVengeance, 3 U.S. (3 Dall.) 297, 299 (1796); see also The Samuel, 14 U.S. (1 Wheat) 9, 14 (1816). At the same time, however, the Judiciary Act excluded seizures made on land or inland, nonnavigable waters from the district court's admiralty jurisdiction. Judiciary Act of $1789 \S 9$. As a result, in the trial of seizures made on land, the district court was to sit as a common law court, and the suit tried to a jury. The Sarah, 21 U.S. (8 Wheat) 390, 391 (1823).

300. Judiciary Act of $1789 \S 9$.

301. See The Sarah, 21 U.S. at 392:

In the trial of all cases of seizure, on land, the courts sits as a court of common law. In cases of seizure made on waters navigable by vessels of ten tons burden and upwards, the court sits as a court of admiralty .... In cases of admiralty and 
Equity jurisdiction was also controversial. This was because equity courts, like admiralty courts, utilized procedures derived from the civil law. The fact that suits in equity were traditionally tried to the court, without the aid of juries, had long made them targets of hostility. As a result, fully functioning equity courts existed in only four states, and suspicions about the power of equity courts permeated the debates over the Judiciary Act. ${ }^{302}$ Much of the discussion focused on concerns about both the lack of juries and the expense traditionally associated with chancery proceedings. Senator Maclay argued against chancery on both grounds. In the judiciary bill, he said, " $[\mathrm{T}]$ he barr between chancery and common law is broken down," with the result that every action might "be tried in the Federal courts by the judges without the intervention of a jury. ${ }^{303}$

The opponents of equity jurisdiction won a partial victory. The bill gave the district courts neither equity nor diversity jurisdiction. The circuit courts, on the other hand, were vested with power to hear "all suits of a civil nature at common law or in equity, ${ }^{304}$ and the Supreme Court was given appellate

maritime jurisdiction, it has been settled, . . that the trial is to be by the court.

See also The Samuel, 14 U.S. at 13-14 (prosecutions under the embargo laws are in admiralty); The Betsey, 8 U.S. at 452 (seizures under the revenue laws made on waters are in the admiralty jurisdiction). But see I KENT, supra note 138, at 350-51:

Congress had a right, in their discretion, to make all such seizures and forfeitures cognizable in the district courts; but it may be a question whether they had any right to declare them to be cases of admiralty jurisdiction, if they were not so by the law of the land when the constitution was made. The constitution secures to the citizen trial by jury in all criminal prosecutions, and in all civil suits at common law, where the value in controversy exceeds 20 dollars. These prosecutions for forfeitures of large and valuable portions of property, under revenue and navigation laws, are highly penal in their consequences; and the government and its officers are always parties, and deeply concerned in the conviction and forfeiture. And if by an act of [C]ongress, or by judicial decisions, the prosecution can be turned over to the admiralty side of the district court, as being neither a criminal prosecution nor a suit at common law, the trial of the cause is then transferred from a jury of the country to the breast of a single judge. It is probable, however, that the judicial act of 1789 did not intend to do more than declare the jurisdiction of the district courts over these cases; and that all prosecutions for penalties and forfeitures upon seizures under laws of impost, navigation and trade, were not to be considered of admiralty jurisdiction ....

302. Only New York, Maryland, South Carolina, and Virginia had fully functioning chancery courts. Pennsylvania, Delaware, and North Carolina lacked any such courts, although common-law courts had some equity powers. Massachusetts and New Hampshire had only common-law courts with limited equity power. The legislatures in Rhode Island and Connecticut exercised some chancery powers, but Georgia had only common-law courts.

303. William MAClaY, JOURNAL of WILliaM MACLAY, UNITEd STATES SENATOR FROM PENNSYLVANIA, 1789-1791 [hereinafter MACLAY'S JOURNAL], reprinted in 9 DOCUMENTARY History OF THE First Federal Congress, 1789-1791, at 109 (Kenneth R. Bowling \& Helen E. Uzit eds., 1988).

304. Judiciary Act of $1789 \$ 11$. 
jurisdiction over decrees in equity from the circuit courts. ${ }^{305}$ Although the drafters deleted a provision requiring jury trials in equity cases from the final bill, the Judiciary Act did provide that "suits in equity shall not be sustained in either of the courts of the United States, in any case where plain, adequate and complete remedy may be had at law. ${ }^{306}$ On its face, this provision had the effect of limiting equity jurisdiction to cases within the traditional purview of the chancery. ${ }^{307}$ The provision was designed to ensure that the common law was the first resort, although the remedy at law must have been "as practical and as efficient to the ends of justice... as the remedy in equity" to obtain dismissal of the bill. ${ }^{308}$

Some senators were also concerned about the possibility that the Supreme Court would have the power to rehear issues of fact on appeal. Because admiralty matters often had important consequences for foreign relations, many other senators were convinced that the Supreme Court should have the ultimate authority to review all aspects of admiralty cases. Thus, when the judiciary bill reached the Senate floor, New Jersey's William Paterson moved to include a provision requiring the circuit courts "to cause the evidence exhibited at the hearing [in admiralty and equity cases] to be reduced to writing." ${ }^{309}$ The provision was probably designed to permit the Supreme Court to have the opportunity to review all the evidence in admiralty cases. Presumably, it would have required the trial court to record the testimony verbatim. The Supreme Court might then be able to determine the facts for itself. Pennsylvania's Maclay led the charge against this proposal, warning that under such a system "delay is so firmly established, and the certainty of procrastination such, that Justice can never be obtained." ${ }^{310}$ Moreover, allowing the Supreme Court to redetermine facts in this way, Maclay said, would result in interminable delays and unreasonable expense. ${ }^{311}$ Maclay's objections won out, so that the final bill contained a provision merely requiring the circuit court "to cause the facts on which they found their sentence or decree, fully to appear upon the record."

305. Id. at $\$ 22,1$ Stat. 73 , at 84 .

306. Id. at $\$ 16,1$ Stat. 73 , at 82 .

307. The clause was "merely declaratory" and made "no alteration whatever in the rules of equity on the subject of legal remedy." Boyce's Ex'rs v. Grundy, 28 U.S. (3 Pet.) 209, 209 (1830).

308. $\quad l d$.

309. Committee Bill $\S 18$, as amended, 5 DoCUMENTARY HISTORY OF THE FIRST FEDERAL CONGRESS 1789-1791, Legislative Histories: Funding Act Through Militia Bill 1183 n.76 (1986) (emphasis added) [hereinafter DHFFC]; 4 DOCUMENTARY HISTORY OF THE SUPREME COURT OF THE UNITED STATES, 1789-1800, at 77 (Maeva Marcus ed., 1992) [hereinafter DHSC]; SENATE LEGISLATIVE JOURNAL, in 1 DOCUMENTARY HISTORY OF THE FIRST FEDERAL CONGRESS, 1789-1791, at 134-135, 138 (1972) [hereinafter 1789 SENATE JOURNAL].

310. MACLAY'S JOURNAL, supra note 303 , at 108.

311. Id.

312. Judiciary Act of $1789, \S 19,1$ Stat. 73,83 (1789) (emphasis added). 
As a result, the Supreme Court would have the benefit of being fully appraised of the factual basis of the lower court's decision without having the power to reconsider the facts themselves.

Continuing sensitivity to the concerns about jury trials eventually led the Senate to include a provision limiting the Supreme Court's appellate power over civil cases to review upon a writ of error. The English form of this particular writ was directed to a lower court of record, and was designed to correct "some supposed mistake in the proceedings." According to Blackstone, a writ of error was available only "upon matter of law arising upon the face of the proceedings; so that no evidence is required to substantiate or support it. ${ }^{314}$ The writ did not reach errors in fact, for such errors could only be reversed by an attaint or a new trial. ${ }^{315}$

\section{ANECONOMIC COMPROMISE}

In the final analysis, the judiciary bill's jury trial provisions amounted to a structural compromise between federalists and antifederalists based on economic lines. In giving the circuit courts jurisdiction over diversity cases, the strong federalists succeeded in preserving a forum for the adjudication of the troublesome British debt cases. However, in preserving jury trial rights in cases brought at law, they sacrificed a degree of legal certainty and opened the door to having such claims nullified by local juries. In the end, it would be left to federalist judges to devise some means of controlling jury verdicts. ${ }^{316}$

Similarly, in giving the district court exclusive cognizance of admiralty matters brought in rem, the judiciary bill ensured that prize cases, the most troublesome admiralty claims, would be heard by federal judges. The Savings Clause, on the other hand, would allow traditional commercial admiralty cases, which had less of a tendency to involve foreign interests, to be commenced in either the federal or state courts with the possibility of a

313. 3 WiLliaM BLACKSTONE, COMMENTARIES *405.

314. Id.

315. Nonetheless, while the drafters of the Judiciary Act took pains to ensure that the Supreme Court would not have the power to review facts on appeal, they did allow the circuit courts just such a power-at least in admiralty cases. Section 19 of the Judiciary Act provided that "an appeal shall be allowed" to the circuit court in admiralty cases if the sum in controversy was in excess of three hundred dollars. Judiciary Act of $1789 \$ 21$. In actions at law, however, the Act required that review of district court judgments be "upon a writ of error." Id. at $\$ 22,1$ Stat. at 73,85 . The difference in terminology cannot have escaped the drafters, and seems to indicate their willingness to continue the practice of reviewing facts on appeal in admiralty (at least in the circuit court), while restricting the circuit courts to reviewing errors in law and procedure in other civil cases. The distinction was most likely calculated to ensure that admiralty cases would be given careful consideration, since admiralty matters were generally thought to have the potential to directly impact the conduct of foreign relations.

316. This they eventually did, as courts made readier use of orders for new trial to prevent what they believed to be erroneous verdicts. See Harrington, Law-Finding, supra note 10, at 41423. 
jury trial in each. However, the fact that admiralty cases were appealable to both the circuit and Supreme Courts-while other cases were appealable only once-ensured that important maritime matters would be fully reviewed by the highest court in the land.

Finally, the realization that the new nation's fiscal security depended on its ability to control the revenue led the judiciary committee to give the district courts jurisdiction over violations of the trade and revenue laws. Although the bill allowed land-based seizures to be tried to juries, and thus minimized complaints about admiralty's role in enforcing inland revenue laws, the fact that seizures made on water would be tried without juries remained a departure from the principles espoused by the erstwhile revolutionaries.

Yet, when all was said and done, no one was completely satisfied with the judiciary bill. Strong federalists thought it too weak, while the advocates of states rights worried that the state courts would be entirely supplanted by the new federal judicial system. Senator Maclay of Pennsylvania complained that the Judiciary Act created a "vile law system, calculated for expense and with a design to draw by degrees all law business into the Federal courts."317 Even James Madison, who at the time of the bill's passage was still firmly in the federalist camp, expressed disappointment in the Judiciary Act. Writing to Edmund Pendleton, Madison asserted that the Act was "defective both in its general structure, and many of its particular regulations," but that "the difficulty of substituting another plan, with the consent of those who agree in disliking the bill, [along with] the defect of time ... will however prevent any radical alteration." ${ }^{, 18}$ It was merely to be hoped "that the system may speedily undergo a reconsideration under the auspices of the Judges who alone will be able perhaps to set it to rights." 319

\section{THE JUDICIARY BILl AND MADISON'S AMENDMENTS}

Fears about the powers of an extensive system of federal courts led to over two hundred amendments being proposed by the various state ratifying conventions. Among these were provisions guaranteeing the right to juries in civil actions and limitations on the exercise of federal question or diversity jurisdiction. Although many federalists in the first Congress remained unconvinced of the need to revise the Constitution, they were willing to accept some modest amendments in the hope that addressing antifederalist concerns would blunt calls for a second constitutional convention. After all, the promise of amendments was all that secured ratification in some of the state conventions, and some federalist candidates for Congress were forced

317. MACLAY'S JOURNAL, supra note 303, at 116.

318. Letter from James Madison to Edmund Pendleton (Sept. 14, 1789), in 12 MADISON PAPERS, supra note 126, at 402.

319. Id. 
to promise that they would support amendments to the Constitution in the event they were elected. ${ }^{320}$ In April 1789, Madison wrote Edmund Randolph advising that "[o]n the subject of amendments nothing has been publicly and very little privately said." ${ }^{321}$ Nonetheless, Madison was sure that "[s]uch [amendments] as I am known to have espoused, will as far as I can gather, be attainable from the federalists, who sufficiently predominate in both branches; though with some, the concurrence will proceed from a spirit of conciliation rather than conviction." 322

Accordingly, in June of 1789, Madison brought before the House a proposal for nine amendments to the Constitution. ${ }^{323}$ The amendments included several changes to Article III as well as a bill of rights. ${ }^{324}$ Predictably, Madison's amendments were met with limited enthusiasm. Fisher Ames complained that Madison had "hunted up all the grievances and complaints of newspapers, all the Articles of Conventions, and the small talk of their debates." ${ }^{325}$ There was, Ames said, "too much of it." ${ }^{326}$ Yet, "[u]pon the whole," Ames thought, "it may do some good towards quieting men who attend to sounds only, and may get the mover some popularity which he wishes." ${ }^{327}$

Virginia's Senator Richard Henry Lee was more cautious. In a letter to Patrick Henry, Lee surmised that "[Madison's] ideas, and those of [Virginia's] Convention, on this subject, are not similar. ${ }^{328}$ Nonetheless, he promised, "We shall carefully attend to this, and when the plan comes to the [S] enate, we shall prepare to abridge, or enlarge, so as to effect, if possible, the wishes of [Virginia's] Legislature. ${ }^{329}$ Further, Lee warned, "from what I hear and see,... many of gur [A]mendments will not succeed, but my hopes are strong that such as may effectually secure civil liberty will not be refused." ${ }^{330}$

The fate of the judiciary bill was, therefore, intimately tied to the

320. See, e.g., Letter from James Madison to George Eve (Jan. 2, 1789), in 11 MADISON PAPERS, supra note 126, at 404; ROBERT RUTLAND, THE BIRTH OF THE BILL OF RIGHTS, 17761791 , at 194-95 (1955).

321. Letter from James Madison to Edmund Randolph (Apr. 12, 1789), in 12 MADISON PAPERS, supra note 126, at 75-76.

322. Id.

323. HOUSE JOURNAL, in 3 DHFFC, supra note 309, at 84; see also 1 ANNALS OF CONG. 424 (Joseph Gales ed., 1789) [hereinafter ANNALS]. Madison's proposals were renumbered and subdivided by the House and Senate before passage.

324. 1 ANNALS, supra note 323 , at 434-35.

325. 1 WORKS OF FISHER AMES, supra note 297 , at 53 .

326. Id.

327. Id.

328. Letter from Richard Henry Lee to Patrick Henry (May 28, 1789), reprinted in 2 THE

LETTERS OF RICHARD HENRY LEE 486 (James C. Ballagh ed., 1914) [hereinafter LEE'S LETTERS].

329. Id.

330. Id. 
success of the amendments because a limited judiciary would lessen the need to craft extensive revisions to the Constitution's judiciary article. The question before Congress in its first session was whether revisions to Article III were necessary to protect the people from an oppressive judiciary or whether the same ends might be achieved by means of well-drafted legislation. Many federalists clearly thought the latter the best course. Others thought differently, however. Richard Henry Lee summed up this second view in a letter to Patrick Henry. "I am satisfied," Lee said, "to see a spirit prevailing that promises to send this system out; free from those vexations and abuses that might have been warranted by the terms of the Constitution." " N31 Nevertheless, he cautioned, "[I]t must never be forgotten ... that the liberties of the people are not so safe under the gracious manner of government, as by the limitation of power." ${ }^{332}$

There is little direct legislative history surrounding the passage of the Seventh Amendment's guarantee of the right to trial by jury in civil casesor indeed, of any of the amendments proposed in the House by James Madison. What is clear is that the jury trial right, like the other proposed amendments, was designed to allay the fears of those who believed that the Constitution did not contain adequate protections for individual liberty. Much of the debate focused on whether it was wise, or practical, to amend the Constitution immediately or whether some trial period might be in order. Madison originally introduced a proposed list of amendments in the House on June 8, $1789 .{ }^{333}$ After some debate about the propriety of considering amendments at this point in its deliberations, the House eventually agreed to refer Madison's amendments, along with proposed amendments submitted by the various state ratifying conventions, to a select committee composed of one member from each of the eleven states then represented in Congress. ${ }^{334}$

\section{Id.}

332. Id.

333. HOUSE JOURNAL, in 3 DHFFC, supra note 309, at 84.

334. Madison first moved that the House resolve itself into a Committee of the Whole to consider the amendments. Id. Some members opposed this suggestion, arguing that there was more important business at hand. At that point in time, the House was already considering several revenue bills and as well as bills establishing the war, treasury, and state departments. Having spent so much time on this work, the members were not inclined to interrupt consideration of "measures which the public were so anxiously expecting." 1 ANNALs, supra note 323 , at 424 (comments of William Smith, S.C.). Others, however, thought that the question of amendments ought to be put off until there was some further experience with the new government. Thus Georgia's James Jackson urged members to "[1] et the Constitution have a fair trial; let it be examined by experience, discover by that test what its errors are, and then talk of amending." Id. at 426. South Carolina's William Smith agreed, noting that "it must appear extremely impolitic to go into the consideration of amending the Government, before it is organized, [and] before it has begun to operate." Id. at 424. It was far more important that Congress set about the work of getting a government up and running before dealing with technical structural change. 
Among Madison's proposals were two amendments to the Judiciary Article dealing with the right to a jury trial in civil cases. The first sought to clarify the Supreme Court's jurisdiction to consider both law and fact. It would have added an additional sentence to Article III, Section 2, Clause 2, and provided that "no appeal to [the Supreme Court] shall be allowed where the value in controversy shall not amount to ___ dollars: nor shall any fact triable by jury, according to the course of the common law, be otherwise re-examinable than may consist with the principles of common law." ${ }^{335}$ Madison's second proposal would have explicitly provided for a right to a jury trial in civil cases. He proposed to strike the third clause of the second section of Article III, ${ }^{336}$ and insert a new one guaranteeing, inter alia, that "[i]n suits at common law, between man and man, the trial by jury, as

Madison responded to these complaints by assuring members that he did not expect the House to interrupt its work entirely. Nevertheless, he said, the amendments had been put off for almost six weeks so as to allow the House to attend to other business, and still the business was not complete. After all, on May 4, 1789, Madison served notice to the House that he would shortly propose amendments to the Constitution and moved that May 25 be set aside for debate. When the date agreed to arrived, Madison moved to postpone the debate until June 8. N.Y. DAILY GAZETTE, May 5, 26, 1789, reprinted in 10 DOCUMENTARY HISTORY OF THE FIRST FEDERAL CONGRESS: DEBATES IN THE HOUSE OF REPRESENTATIVES, APRIL-MAY 1789, at 409, 780 (Charlene Bangs Bickford et al. eds., 1992). Consequently, he introduced the amendments in an effort to prove to their constituents that Congress was showing due deference to "a subject they have much at heart." 1 ANNALS, supra note 323, at 427. Further, Madison warned, "[I]f we continue to postpone from time to time, and refuse to let the subject come into view, it may occasion suspicions, which, though not well founded, may tend to inflame or prejudice the public mind against our decisions." Id. at 428. Madison's effort to convince the House to take up the amendments was supported by fellow Virginians Alexander White and John Page. White argued that consideration of the amendments would "tranquilize the public mind," while Page cautioned that those favoring extensive revisions would become impatient and demand a second constitutional convention. Id. at 428-29.

No doubt concerned about appearances, the House agreed to refer the proposed amendments to the Committee of the Whole. No further action was taken on them, however, until July 21, when Fisher Ames moved that a select committee be appointed for the purpose. Ames's motion passed, and a committee consisting of one member from each state was appointed to consider revisions to the Constitution. HOUSE JOURNAL, in 3 DHFFC, supra note 309 , at $84,117$.

335. 1 ANNALs, supra note 323, at 435 . Madison intended to leave to the House the precise limits of the jurisdictional amount. The proposed limitations on the Supreme Court's appellate jurisdiction was probably inspired by the amendments suggested by the Massachusetts and New Hampshire conventions. Cf. 1 ELLIOT's DEBATES, supra note 40, at 323, 326 (proposing a limitation of three thousand dollars).

336. The clause provides as follows:

The Trial of all Crimes, except in Cases of Impeachment, shall be by Jury; and such Trial shall be held in the State where the said Crimes shall have been committed; but when not committed within any State, the Trial shall be at such Place or Places as the Congress may by Law have directed.

U.S. CONST. art. III, § 2, cl. 3. 
one of the best securities to the rights of the people, ought to remain inviolate." 337

On July 28, 1789 , the committee to whom the amendments had been referred made its report to the House. ${ }^{338}$ It modified Madison's proposal concerning appeals of fact by inserting a jurisdictional amount in controversy requirement of $\$ 1000 .^{339}$ The committee edited Madison's jury trial amendment to provide that "[i]n suits at common law the right to trial by jury shall be preserved." 340 The House accepted the committee report and set aside August 13 for debate on the amendments. ${ }^{341}$

When the time for debate arrived, many members of the House again urged postponing consideration of the amendments. As it was, they noted, Congress was set to adjourn within a month, and a great deal of work was left to be done. South Carolina's William Smith argued that the House should devote its efforts to getting the government organized. By this time, the Senate had passed the judiciary bill and forwarded it to the House for passage. The Constitution, Smith said, "establishes three branches to constitute a whole; the Legislative and Executive are now in existence, but the Judicial is uncreated." ${ }^{342}$ For his part, therefore, Smith "could not conceive the necessity of going into any alterations of the Government until the Government itself was perfected." ${ }^{343} \mathrm{He}$ also warned the members that, without a system of courts, "not a single part of the revenue system can operate; no breach of your laws can be punished; illicit trade cannot be prevented." "344 It was essential, therefore, that the House attend to the judiciary bill, for " $[\mathrm{g}]$ reater harm will arise from delaying the establishment of the Judicial system, than can possibly grow from a delay of the other subject." ${ }^{345}$ Massachusetts' Elbridge Gerry joined in Smith's objection, and urged the House to put off consideration of the amendments until the

337. I ANNALS, supra note 323, at 435. Madison's new clause guaranteed a trial in the vicinage in criminal cases and presentment by a grand jury in capital cases.

338. HOUSE JOURNAL, in 3 DHFFC, supra note 309, at 124.

339. The committee version thus read as follows: "But no appeal to such court shall be allowed, where the value in controversy shall not amount to one thousand dollars, nor shall any fact, triable by a Jury according to the course of the common law, be otherwise re-examinable than according to the rules of common law." House Committee Report (July 28, 1789), in 4 DHFFC, supra note 309 , at 27, 29-30.

340. Id. at 30.

341. After the first reading, the committee report was ordered to lie on the table. On August 3, Madison moved to have the report made an order of the day for Wednesday, August 12, but the House spent most of that day debating a bill providing for expenses incurred due to negotiating with Indian tribes. The debate on the amendments was thus put off until Thursday, August 13. HOUSE JOURNAL, in 3 DHFFC, supra note 309, at 124, 130, 147, 148.

342. 1 ANNALS, supra note 323 , at 705.

343. Id.

344. Id.

345. Id. 
judiciary and revenue bills were complete. ${ }^{346}$ Madison responded to these entreaties by admitting the importance of the judiciary bill, and noted that "a great number of the community are solicitous to see the Government carried into operation." ${ }^{347}$ At the same time, he said, there was "a considerable part also anxious to secure those rights which they are apprehensive are endangered by the present Constitution." 348

The House put aside consideration of the judiciary bill and proceeded to debate the amendments. The first discussion of the jury trial proposals occurred on August 17, 1789, with the House sitting as a Committee of the Whole. When the House took up Madison's proposed jurisdictional limit on appeals, Egbert Benson of New York immediately moved to strike the limit on the grounds that an amount in controversy requirement would prevent cases of great constitutional moment from coming before the Supreme Court because only a small amount of money was involved. ${ }^{349}$ Although Madison in essence agreed with Benson's point, he insisted that some limit must be put on appeals. He thought there was "little danger" that any court in the United States would admit an appeal where the matter in dispute did not amount to a thousand dollars. Still, he recalled that "the possibility of such an event has excited in the minds of many citizens the greatest apprehension that persons of opulence would carry a cause from the extremities of the Union to the Supreme Court, and thereby prevent the due administration of justice." ${ }^{350}$ Shortly thereafter, the $\$ 1000$ limit was adopted. ${ }^{351}$ The part of the amendment concerning the review of facts on appeal drew no discussion. The Committee of the Whole took up Madison's second jury provision the following day. It adopted the committee's formulation, that "the right to trial by jury shall be preserved," without any apparent debate. ${ }^{352}$ Three days later, the House passed all the amendments and sent them to the Senate for its approval. ${ }^{353}$

The Senate considered the first of the proposed amendments concerning the civil jury on September 4,1789 . The final House version of

\footnotetext{
346. Id.

347. 1 ANNALS, supra note 323 , at 705.

348. Id. at 706 .

349. Id. at 755. In making this motion, Benson no doubt had in mind the Ship Money cases, in which Englishmen opposed the payment of an inland levy made on them by Charles I, without parliamentary authorization. John Hampden, a cousin of Oliver Cromwell, was eventually summoned before the Exchequer Court for refusing to pay the sum of twenty shillings. The King v. Hampden, 3 St. Trials 846 (1637).

350. 1 ANNALS, supra note 323 , at 755 .

351. Id. at 756 .

352. Id. at 760. A brief discussion was had over a series of amendments proposed by Thomas Tucker (S.C.), one of which would have limited Congress to establishing only lower courts. If adopted, such a provision would have made most of the discussion concerning jury trials a nullity, since, as noted elsewhere, admiralty courts did not use juries.

353. HOUSE JOURNAL, in 3 DHFFC, supra note 309, at 166.
} 
this amendment provided as follows:

No appeal to the Supreme Court of the United States, shall be allowed, where the value in controversy shall not amount to one thousand dollars, nor shall any fact, triable by a Jury according to the course of the common law, be otherwise re-examinable, than according to the rules of common law. ${ }^{354}$

The Senate deleted the language imposing a jurisdictional amount on appeals to the Supreme Court; so that the amendment read: "No fact, triable by a Jury according to the course of common law, shall be otherwise, reexaminable in any court of the United States, than according to the rules of common law." second proposal on juries to include a jurisdictional limit on jury trials. The Senate's version now read as follows: "In suits at common law, 'where the consideration exceeds twenty dollars' the right of trial by jury shall be preserved. ${ }^{356}$ On September 9, 1789 the Senate renumbered the articles and joined the two proposals concerning jury trials into a single amendment. The final Senate version was numbered as the ninth amendment and provided that:

In suits at common law, where the value in controversy shall exceed twenty dollars, the right of trial by Jury shall be preserved, and no fact tried by a Jury, shall be otherwise re-examined in any Court of the United States, than according to the rules of the common law. ${ }^{357}$

The Senate then returned amendments to the House for its concurrence.

The House originally rejected the Senate's version of the jury trial amendment on September 21, $1789 .{ }^{358}$ It appears that the sticking point remained the limit on appeals to the Supreme Court. The House, no doubt reflecting its populist composition, insisted on the need to prevent cases involving trifling sums from being lodged in the Supreme Court, thus forcing small debtors or farmers to expend large sums defending their suits many miles from their homes. The Senate, on the other hand, thought such a limitation was "unnecessary, and might be embarrassing in questions of

354. The amendments were read in the Senate on Tuesday, August 25, 1789. Echoing some of the arguments made in the House shortly after Madison introduced them, South Carolina's Ralph Izard immediately moved to postpone consideration of the amendments until Congress convened for its second session in December 1789. Izard's motion was defeated, although the Senate put off consideration of the amendments until September 2. SENATE JOURNAL, in 1 DHFFC, supra note 309 , at 134-35, 137.

355. Id. at 155 .

356. Id. at 158 .

357. Id. at 167.

358. HOUSE JOURNAL, in 3 DHFFG, supra note 309, at 217. 
national or constitutional importance. ${ }^{359}$ Perhaps recalling the Ship Money Cases, ${ }^{360}$ the Senate thought that important constitutional questions might be implicated in cases involving small amounts and refused to budge. The majority of senators believed that the problem was best handled by the judiciary bill's limitation on appeals in diversity cases. ${ }^{361}$ A conference committee, appointed to resolve the differences between the two bodies, eventually recommended that the House agree to the Senate version. The House and Senate adopted the articles of amendment within a few days, leaving the Senate's civil jury trial provision intact. The Congress then transmitted the amendments to the several states for their approval. ${ }^{362}$

\section{WHAT WAS PRESERVED?}

In drafting his jury trial provisions, Madison had a number of models from which to work. Several of the state ratifying conventions had passed "recommendatory amendments" dealing with jury trials, and defeated antifederalists in both Pennsylvania and Maryland issued minority reports containing amendments they thought necessary. Most of these proposals contained variations on the same theme, although each would have provided for a differing level of protection. Moreover, each of the different proposals would have resulted in dramatically different versions of jury practice in the federal courts. Indeed, in defending the Philadelphia Convention against the charge that it sought to abolish the right to trial by jury, Alexander Hamilton used the various amendments put forth by the conventions to show how "arduous" was the "task of fashioning a provision in such a form as not to express too little to answer the purpose or too much to be advisable. Or which might not have opened other sources of opposition to the great and essential objective of introducing a firm national government. ${ }^{363}$ In Hamilton's view, at least, none of the proposals put forward by the states was up to the task of resolving the difficulties posed by the variations in state court jury practice.

For example, the Pennsylvania convention's minority report proposed an amendment declaring that "in controversies respecting property, and in suits between man and man, trial by jury shall remain as heretofore, as well

359. Letter from James Madison to Edmund Pendleton (Sept. 23, 1789), in 12 MADISON PAPERS, supra note 126, at 418; see also James Madison to Edmund Pendleton (Sept. 14, 1789), in 12 MADISON PAPERS, supra note 126, at 402 (discussing a fear of inconvenience with the limitations of the amendments).

360. The King v. Hampden, 3 St. Trials 846 (1637).

361. The judiciary bill limited appeals in diversity cases to actions involving the sum of $\$ 2000$. Judiciary Act of 1789, § 22, 1 Stat. 73, 84 (1789).

362. HOUSE JOURNAL, in 3 DHFFC, supra note 309, at 228, 233; SENATE JOURNAL, in 1 DHFFC, supra note 309 , at 192, 198.

363. THE FEDERALIST No. 83 (Alexander Hamilton). 
in the federal courts, as in those of the several states." ${ }^{364}$ According to Hamilton, this amendment would have required that cases brought in federal court be tried by a jury if the courts of the state in which the federal court sat would have empaneled a jury. However, as Hamilton noted, state court jury practices differed greatly. In Connecticut, for example, admiralty cases were tried by juries, while in Pennsylvania, the common-law courts exercised equity jurisdiction. Consequently, the rule proposed by Pennsylvania's minority was "capricious" in the extreme, for "[w] hether the cause should be tried with or without a jury, would depend, in a great number of cases, on the accidental situation of the court and parties." ${ }^{365}$

The Massachusetts convention, on the other hand, recommended that "[i]n civil actions between citizens of different States, every issue of fact arising in actions at common law, shall be tried by a jury, if the parties, or either of them, request it." ${ }^{366}$ In his effort to convince readers that a Bill of Rights was unnecessary, Hamilton treated this proposal as if it meant the same thing as Pennsylvania's. In his view, the term "actions at common law" was too vague to provide any clear rule as to when juries would be required in civil cases. ${ }^{367}$ This was because the rules for distinguishing between a common-law action and a suit in equity differed widely in the several states. As a result, the Massachusetts provision could not "operate as a general regulation, until some uniform plan, with respect to the limits of common law and equitable jurisdiction, shall be adopted by the different states." According to Hamilton, the Pennsylvania and Massachusetts proposals were defective because each made the right to jury trial dependent on state law. The result, therefore, would be a disparity in the right to jury trial in the various federal courts. ${ }^{369}$

364. The Address and Reasons of Dissent of the Minority of the Convention of the State of Pennsylvania to Their Constituents, (Dec. 18, 1787), reprinted in 3 ANTI-FEDERALIST, supra note 163 , at $145,151$.

365. THE FEDERALIST NO. 83 (Alexander Hamilton).

366. 1 ELLIOT'S DEBATES, supra note 40 , at 323. New Hampshire passed an amendment identical to that proposed by Massachusetts. Id. at 326.

367. In drafting this proposal, the Massachusetts convention likely had in mind the provision in that state's bill of rights, which clearly made distinctions between actions at law, where juries were used, and those in equity and in admiralty. In Massachusetts, the right to jury was preserved "[i]n all controversies concerning property, and in all suits between two or more persons, except in cases in which it has heretofore been otherwise used and practised." MASSACHUSETTS DECLARATION OF RIGHTS art. XV (1780), in 3 AMERICAN CHARTERS, CONSTITUTIONS AND ORGANIC LAwS 1492-1908, at 1891-92 (Francis Newton Thorpe ed., 1909).

368. Id.

369. Whether because he was trying to win an argument or because he did not believe elaboration necessary, Hamilton's assertion that the Pennsylvania and Massachusetts amendments meant the same thing is clearly erroneous. At a minimum, Massachusetts's version would have applied to diversity cases only. It might not have been applicable to other cases, and thus juries would have been used in federal question cases as Congress saw fit. See, e.g., Krauss, supra note 35 , at 417-19. 
Two other states, Maryland and New York, proposed amendments which seemed to provide a uniform rule for federal cases. The Maryland convention's minority proposed that the trial by jury be available "in all actions on debts or contracts, and in all other controversies respecting property" as well as "in all cases of trespasses done within the body of a county. ${ }^{370}$ This proposal might have simplified matters somewhat because it provided for a jury trial only in those cases which would have traditionally been regarded as suits at common law, such as suits in debt, assumpsit and trespass. New York's amendment-while less of a proposal than a declaration-would have provided for a jury trial whenever such a right existed according to the common law of England. ${ }^{371}$

In no state was the right to a civil jury trial more hotly debated than in Virginia. Virginia's convention proposed a bill of rights which declared that "in controversies respecting property, and in suits between man and man, the ancient trial by jury is one of the greatest securities to the rights of the people, and to remain sacred and inviolable. ${ }^{\text {"372 }}$ Virginia's proposal was unlike the others in that it merely declared that civil jury trials ought to be preserved and would not have resulted in any specific change to the text of Article III. ${ }^{373}$ However, the Virginia convention also proposed that the jurisdiction of the lower federal courts be limited to admiralty cases. In addition, the Virginia convention proposed that no federal court would have

370. 2 ELLIOT'S DEBATES supra note 40 , at 550.

371. The New York amendment read as follows: "That the trial by jury, in the extent that it obtains by the common law of England, is one of the greatest securities to the rights of a free people, and ought to remain inviolate." 1 ELLIOT'S DEBATES, supra note 40 , at 328.

372. 3 ELLIOT'S DEBATES, supra note 40 , at 658 . In fact, the Virginia jury trial provision was itself modeled on a similar provision in that state's own 1776 Declaration of Rights. That clause provided that in controversies respecting property, and in suits between man and man, the ancient trial by jury is preferable to any other, and ought to be held sacred." VIRGINIA DECLARATION OF RIGHTS \$11 (1776).

373. Moreover, to some extent, at least, Virginia's declaration was a nullity, because that state's ratifying convention had also proposed limiting the jurisdiction of the lower federal courts to admiralty cases only. Virginia's convention proposed altering Article III to provide only that "the judicial power of the United States ... be vested in one Supreme Court, and in such courts of Admiralty as Congress may from time to time ordain and establish." 3 ELLIOT'S DEBATES, supra note 40 , at 660 . A jury trial might only be available, therefore, in suits arising under treaties or cases involving ambassadors, both of which would have remained within the Supreme Court's original jurisdiction. All other civil suits would have been tried in state courts in the first instance. Virginia also proposed that the judicial power extend only to

\begin{abstract}
cases in law and equity arising under treaties made, or which shall be made, under the authority of the United States; to all cases affecting ambassadors, other foreign ministers, and consuls; to all cases of admiralty and maritime jurisdiction; to controversies to which the United States shall be a party; to controversies between two or more states, and between parties claiming lands under the grants of different states.
\end{abstract}

Id. The Supreme Court had original jurisdiction only over cases involving treaties and ambassadors. In all other cases, its jurisdiction was appellate only. Id. 
jurisdiction over claims arising before ratification of the Constitution. As one contemporary observer noted, the "obvious effect of these restrictions would have been to divest the general government of all control over many questions arising under the Constitution and Laws of the United States, [as well as] all questions relative to infractions of the fourth article of the treaty of peace [concerning recovery of British debts]."

As a result, it appears that Virginia's convention did not intend its amendments to protect jury trial rights in the federal courts. Rather, the Virginia amendment was probably designed to ensure that the verdicts of state court juries would be protected from reversal on appeal to the Supreme Court. Debtor interests clearly hoped to leave the trial of British debt cases in the state courts which had thus far proved quite hospitable to their interests. Debtors thus thought that provisions limiting the jurisdiction of the federal courts were necessary to prevent creditors from circumventing the state courts. After all, there was a great deal of anxiety during the course of the ratification debates over the possibility that the Supreme Court would use Article III's grant of appellate jurisdiction over law and fact to redetermine facts found by a jury. Virginia's provision was crafted to forestall just that possibility.

Some scholars believe that Madison relied on the Virginia convention's proposal when drafting the Seventh Amendment. This is only partly true. In preparing his civil jury trial guarantee, Madison borrowed only the part of the Virginia convention's proposal that was drawn from the Virginia bill of rights and which declared that the right to jury trial "ought to remain sacred." ${ }^{375}$ He ignored the remaining provisions, especially those parts that would have severely limited the power of the federal courts. Nevertheless, one is left to wonder why Madison chose to rely on Virginia's rather vague assertion of jury rights when other state conventions had put forth far more concrete proposals. Given the long-running controversy over the scope of the federal courts' jurisdiction and the continuing agitation over the omission of a civil jury trial right, would it not have been better to specifically define the circumstances under which that right was to be "preserved?"

In fact, however, Madison largely ignored the proposals put forth by the various state conventions, many of which would have resulted in substantial shifts in the balance of power between the state and federal governments. Instead, in selecting his proposed amendments, Madison decided to "exploit [the] seams in the Antifederalist position," ignoring alterations in the institutions defined by the Constitution, and opting instead for "a list of

374. OLIVER WOLCUTT, BRITISH INFLUENCE ON THE AFFAIRS OF THE UNITED STATES, PROVED AND EXPLAINED 10 (1804).

375. Amendments Proposed by the Virginia Convention (July 27, 1788), reprinted in 4 DHFFC, supra note 309 , at $15,16$. 
rights that would connect clearly with the preferences of state governments but would not increase state power." ${ }^{376}$ Madison's sources, therefore, were not the amendments proposed by the state conventions. They were, rather, the state bills of rights adopted between 1776 and 1787. Madison "effectively extracted the least common denominator from these state bills of right, excepting those rights that might reduce the power of the national government." 377

Madison's choice of language was consistent with the state bills of rights on which he relied. Those bills had a long history of "laying out the common values, interests, and goals that bound [Americans] as a people" in terms that were hortatory in scope and structure. ${ }^{378}$ In the earliest years, state bills of rights tended to rely on the Scriptures for their formulations until the growing diversity of the population made the use of biblical references problematic. In time, therefore, state bills of rights abandoned scriptural references and utilized "admonitory language" designed to set forth the "fundamental, shared values" of the people in very general terms. ${ }^{379}$ Thus, the North Carolina Bill of Rights proclaimed that the freedom of the press is "one of the great bulwarks of liberty" which "ought never to be restrained;";30 and Maryland's bill of rights provided that the executive, legislative, and judicial branches of government "ought to be forever separate and distinct from each other." ${ }^{\text {,31 }}$ Similarly, Pennsylvania's Constitution of 1776 declared that general warrants "ought not to be granted," 382 while Virginia's Declaration of Rights asserted that "excessive bail ought not to be required."

Such language was deliberately open-ended, as a statement of shared values often must be, and did not confer any right that was legally enforceable by the populace. ${ }^{384}$ The admonitory form allowed the people to set forth their ideals without the need to establish black-letter rules applicable in any particular case. In drafting his amendments, therefore, Madison relied on this well-known admonitory form, especially with regard to the Seventh Amendment. Madison's proposed jury trial amendment mirrored similar clauses in state bills of rights, none of which contained

376. Donald S. Lutz, The Pedigree of the Bill of Rights, in THE BILL OF RIGHTS: GOVERNMENT PROSCRIBED 42, 52-53 (Ronald Hoffman \& Peter J. Albert eds., 1997).

377. Id. at 54 .

378. Id. at 64 .

379. Id.

380. NORTH CAROLINA DECLARATION OF RIGHTS $§$ XV (1776).

381. MARYLAND DECLARATION OF RIGHTS $§$ VI (1776).

382. PENNSYLVANIA DECLARATION OF RIGHTS $§ X ~(1776)$.

383. VIRGINIA DECLARATION OF RIGHTS $\$ 9$ (1776).

384. See, e.g., DELAWARE DECLARATION OF RIGHTS $\$ 13$ (1776) ("That Trial by Jury of Facts where they arise is one of the greatest Securities of the Lives, Liberties and Estates of the People."); MARYLAND DeClaration OF Rights $\$ 18$ (1776) ("That the trial of facts, where they arise, is one of the greatest securities of the lives, liberties, and estate of the people."). 
anything like a black-letter rule. Instead, state jury trial clauses merely declared that the right to a jury trial in civil cases "ought to be held sacred," 385 or should "remain inviolate forever."

The use of the admonitory form provided the means by which passage of a civil jury trial guarantee might be assured. In drafting his proposals, Madison's first task was to find a formula by which a uniform rule might be adopted for federal trials while still accommodating the various approaches already present in state court practice. There was no consensus on the exact extent of the jury's power. ${ }^{387}$ Indeed, whether the jury would continue to have the power to find both law and fact, and whether the courts or Congress would have the power to craft mechanisms to control jury verdicts were not discussed in any of the state ratifying conventions. This is probably because the practice of instructing and controlling juries differed so greatly among the various states. ${ }^{388}$ Therefore, knowing that a specific statement would be bound to arouse opposition from either side, Madison found a solution in ambiguity.

After all, Madison himself seems not to have believed that amendments were necessary. While he may not have been entirely happy with the Constitution's final form, Madison clearly believed that it was the best that could have been obtained at the time. As a result, he feared any attempt to alter it so soon and was especially concerned about the continuing calls for a second constitutional convention. ${ }^{389}$ As far as Madison was concerned, the amendments were an attempt to quiet the minds of the "great number of our constituents who are dissatisfied with [the Constitution]." "In his view, "a great body of the people" were "inclined to join their support to the cause of Federalism," if the Constitution provided more definite protections for the liberty of the citizen. ${ }^{391}$ Although Madison thought that such written guarantees were unnecessary, he nonetheless urged their inclusion in the

385. PENNNSYLVANIA DECLARATION OF RIGHTS $§$ XI (1776); VIRGINIA DECLARATION OF RightS $\S 11$; see also MASS. CONST. of 1780 , pt. 1 , art. $1 \mathrm{~b}$ (declaring that the right to a jury trial "shall be held sacred"); N.H. CONST. of 1784, pt. 1, art. I, $\$ 20$ (trial by jury "shall be held sacred"); VT. CONST. of 1786 , ch. I, $\$ 14$ (trial by jury "ought to be held sacred").

386. N.Y. CONST. of $1777, \S 41$; see also N.C. CONST. of $1776, \S 14$ ("[T] he ancient mode of trial by jury, is one of the best securities of the people, and ought to remain sacred and inviolable."); S.C. CoNST. of 1790 , art. $9, \S 6$ (trial by jury "shall be inviolably preserved").

387. Henderson, supra note 177, at 299.

388. See id. at 299-320 (discussing a variety of jury trial practice in civil cases).

389. See, e.g., I ANNALS, supra note 323 , at 433 :

I should be unwilling to see a door opened for a reconsideration of the whole structure of the Government-for a re-consideration of the principles and the substance of the powers given; because I doubt, if such a door were opened, we should be very likely to stop at that point which would be safe to the Government itself.

390. Id. at 432 .

391. Id. 
spirit of "amity and moderation." 392 Of equal importance to Madison was the fact that two states had not yet ratified the Constitution. Consequently, amending the Constitution in the manner proposed would, he argued, produce a reunion with North Carolina and Rhode Island "as soon as possible." 393

On introducing the amendments, Madison paid homage to the importance of the right to trial by jury, noting that such a right "is as essential to secure the liberty of the people as any one of the pre-existent rights of nature. ${ }^{394}$ However, nothing in his speech to the House indicates that Madison was attempting any grand synthesis or design. ${ }^{395}$ With respect to the jury trial amendments, at least, he seems not to have had any particular theory or purpose other than to neutralize the political opposition. Indeed, Madison hinted that his proposals were intended merely to "satisfy the public mind" concerning the "inconvenience" that "has been apprehended to suitors from the distance they would be dragged to obtain justice in the Supreme Court of the United States, upon an appeal on an action for a small debt. ${ }^{2396}$ Consequently, he suggested a jurisdictional limit on appeals, although he himself had no particular sum in mind. With respect to the "regulations" concerning jury trials, Madison merely hoped that the alterations he proposed would "quiet and reconcile the minds of the people to [the judiciary article]. ${ }^{397}$

Madison's proposed amendments were also the result of political calculation. As a candidate for Congress from Virginia, Madison found himself compelled to support amendments similar to those proposed by his state's convention. Moreover, in letters to various correspondents, Madison repeatedly asserted that his choice of amendments and language was "limited to points which are important in the eyes of many and... objectionable in those of none." ${ }^{398}$ Madison was keenly aware that "[n] othing of a controvertible nature [could] be expected to make its way thro' the caprice \& discord of opinions which would encounter it in Congs. when $2 / 3$ must concur in each House, $\&$ in the State Legislatures $3 / 4$ of which will be requisite to its final success. ${ }^{399} \mathrm{He}$, therefore, sought amendments that would "remov[e] the fears of the discontented" while "avoiding all such alterations as would either displease the adverse side, or

392. Id. at 433 .

393. Id. at 432 .

394. 1 ANNALS, supra note 323 , at 441 .

395. One commentator has noted that Madison's speech "was perhaps the most lukewarm introduction in political history." Lutz, supra note 376, at 69.

396. 1 ANNALS, supra note 323 , at 441.

397. Id.

398. Letter from James Madison to Edmund Randolph (June 15, 1789), in MADISON PAPERS, supra note 126, at 219.

399. Id. 
endanger the success of the measure." ${ }^{400}$ Seen in this light, Madison's decision to rely on the language of state bills of rights was a masterstroke. In mimicking the language that the states themselves had used to protect the right to jury trial, Madison neutralized opposition to his jury trial amendment. Antifederalists could not reasonably complain about the lack of specificity in Madison's jury trial guarantee when those in state bills of rights were no stronger. Similarly, federalists could not really condemn a clause in the federal Constitution that used language identical to those of their own states.

The diversity in state court jury practice made specificity a liability. Consequently, Madison was faced with precisely the same problem that supporters of the Constitution asserted had prevented the Philadelphia Convention from reaching agreement when it considered the civil jury question. His proposal, therefore, merely "preserved" the status quo and allowed both proponents and opponents of the Constitution to read into it as they were wont. ${ }^{401}$ Clearly, Madison had other more concrete proposals with which to work. The Pennsylvania proposal might have provided for a dynamic conformity along the lines discussed by Professor Amar, but that proposal was quite soundly rejected by Hamilton and others. ${ }^{402}$ Similarly, the Massachusetts and Maryland amendments would have specified certain classes of cases in which jury trials would be required. ${ }^{403}$ The New York proposal, on the other hand, contained language that would have preserved the right to trial by jury to "the extent that it obtains by the common law of England." had truly intended to adopt the common law of England as the test of jury rights, it is more than a little strange that they would have ignored the New York language. As it is, there is not a single shred of evidence in the written record indicating that anyone in the first Congress ever intended the language of the Seventh Amendment to refer to the common law of England.

400. Letter from James Madison to Samuel Johnson (June 21, 1789), in MAdison PAPERs, supra note 126, at 249; see also Letter from James Madison to Tench Coxe (June 24, 1789), in MADISON PAPERS, supra note 126, at 257; Letter from James Madison to Thomas Jefferson (May 27,1789 ), in MADISON PAPERS, supra note 126, at 185-86 (writing about the troubles with the Houses of Congress and proposed amendments).

401. In describing the difficulties of getting the Senate to agree on a definition of "vicinage" applicable to criminal juries, Madison noted that "in most of the States the practice is different" and thus there was an "irreconciliable [sic] difference of ideas on the subject." Letter from James Madison to Edmund Pendleton (Sept. 23, 1789), in MADISON PAPERS, supra note 126 , at $418-20$.

402. See supra notes $39-42$ and accompanying text (discussing Hamilton's objections to "dynamic conformity").

403. Massachusetts's proposal would have provided for jury trials in diversity cases brought at law. 1 ELLIOT'S DEBATES, supra note 40, at 323. Maryland's would have required a jury trial in contract and property actions. 2 ELIIOT'S DEBATES, supra note 40, at $\mathbf{5 5 0}$.

404. 1 ELIIOT'S DEBATES, supra note 40 , at 328. 
In truth, Madison rejected all of these suggestions in favor of the jury trial formula in the Virginia bill of rights. ${ }^{405}$ As noted above, the Virginia convention passed several resolutions dealing with jury trials. One would have eliminated the jurisdiction of federal courts in common-law cases and cases arising before ratification of the Constitution. ${ }^{406}$ The other declared that the right to trial by jury "ought to remain sacred and inviolable. ${ }^{807} \mathrm{Read}$ together, these clauses indicate an intention to protect state court jury trial verdicts from reversal by the Supreme Court, because the only cases left to lower federal courts under Virginia's plan would have been those in admiralty which were tried without juries. Therefore, the most that could be said of Madison's original choice of language is that it was meant to answer antifederalist concerns about the Supreme Court's jurisdiction over law and fact. Of course, using Virginia's phrasing had the added benefit of allowing Madison to pay due deference to the wishes of his own constituents. Still, the most likely scenario is that Madison preferred Virginia's language because it was the most ambiguous. This language was repeated in the proposals of the Virginia ratifying convention and would also be easily recognizable to congressmen from other states, such as Pennsylvania, New York, and Massachusetts, where bills of rights contained nearly identical phrasing. ${ }^{408}$ The proposals put forward by the various state conventions, on the other hand, were far more substantive, each providing for vastly differing requirements concerning juries, and each likely to arouse opposition from some segment of the political spectrum.

It must also be remembered that the issue at the heart of the entire controversy over civil jury trials was the right of juries to find both law and fact. The antifederalist critique of the Constitution was based on a desire to protect the people from oppressive government, and more specifically, to prevent the government from altering legal rules or regimes to disturb the tenuous economic balance between debtors and creditors. Antifederalists valued juries not merely because they were a check on the arbitrary actions of corrupt judges. Rather, juries were desirable precisely because of the expectation that they would use their law-finding function to effect change in the law outside of the legislative process. Where debtors and revenue laws were concerned, therefore, the antifederalists expected juries to use their

405. As noted above, however, Madison only adopted that part of Virginia's proposed amendment which was drawn from the Virginia bill of rights and which declared that the right to a jury trial ought to remain "sacred." He rejected the remaining portions of Virginia's amendments which would have made substantial changes to the Constitution's judiciary article. See supra text accompanying notes 372-74.

406. See supra note 373 (discussing Virginia convention jury trial amendment).

407. Amendments Proposed by the Virginia Convention (July 27, 1788), reprinted in 4 DHFFC, supra note 309 , at 15, 16.

408. See supra text accompanying footnotes 364-74 (discussing the text of the states' bills of rights). 
power to come to conclusions opposite those that might be reached by judges trying the case alone. Federalists understood this problem as well. It was because they, too, believed that juries had a law-finding function that most federalists feared allowing juries to dispose of prize, debt, and revenue matters. Therefore, the debate over the right to jury trial in civil cases was really a debate about the power of juries to find both law and fact in cases having significant economic consequences.

It is important to bear in mind, however, that this debate was over by the time the subject of the amendments came before the House. Realizing that the successful creation of the third branch of government depended on reaching compromises between strong and weak federalists, the Senate crafted the judiciary bill in such a way as to strike a balance between those who favored broad powers for the federal courts and those who advocated a more limited role. In any event, the trade-offs in the judiciary bill went a long way toward mollifying antifederalist fears. As a result, by the time the House took up the amendments in late-July 1789, the terms of the judiciary bill were a matter of public record. Nearly everyone both in and out of Congress knew that the Senate had preserved the right to jury trial in diversity cases, while leaving admiralty and revenue suits to be tried, in most instances, ${ }^{409}$ without a jury. The deal had been struck and, to a large degree, the antifederalists had won: suits that might have a direct effect on national interests, such as prize cases or civil prosecutions under the revenue laws, would be tried by judges sitting alone, while cases based on private-law rights would continue to be heard by juries. Strong federalists thus gave up their goal of limiting jury trial rights in all cases that might have an impact on the nation's economic and commercial development in exchange for the acquiescence of the weaker federalists in the creation of an extensive system of lower courts.

With respect to protections for the civil jury, therefore, there was really little left for the House to debate. While no one was fully satisfied by the judiciary bill, it was clear that the courts had to be established quickly in order for the government to function effectively. Moreover, Congress was set to adjourn in early September, and the Congress still needed to complete a revenue bill, along with bills to compensate federal officials, conduct treaty negotiations with the Indians, establish a permanent seat of government, and regulate trade. As a result, comparatively little time was actually spent debating the amendments in the House. ${ }^{410}$ Indeed, the House seems to have

409. See Judiciary Act of $1789, \S \S 9,12,1$ Stat $73,77,80$ (1789) (requiring juries in diversity actions in circuit courts, while permitting admiralty cases to be tried in the district courts without juries).

410. For example, most of the first day of debate (August 13) was devoted to the question of whether the amendments were to be incorporated into the body of the Constitution as drafted in Philadelphia, or whether they were to be appended. The second day (August 14) saw a debate over an amendment to the preamble and the apportionment of representatives. 
passed over Madison's two proposals concerning jury trials with almost no discussion. ${ }^{411}$

The "battle" over the right to jury trial was, after all, not fought at the level of political theory. No one in the House or Senate ever put forward a coherent synthesis of the Seventh Amendment or what it attempted to "preserve." In reality, the Amendment was something of a sop, designed to mollify the antifederalists without arousing too much hostility from federalists who thought no amendments were necessary. Madison repeatedly admitted as much in letters written to various correspondents during the debates themselves. Writing to Philadelphia's Richard Peters, Madison acknowledged that he thought amendments protecting rights were "less necessary in a republic," and repeated his assertion that something had to be done to head off calls for a second convention. ${ }^{412}$ With no little irony, he also noted that passing the proposed amendments would go a long way toward strengthening the powers of the federal government, because they would "kill the opposition every where, and by putting an end to the disaffection to the Govt. itself, enable the administration to venture on measures not otherwise safe. ${ }^{413}$ Others, both federalist and antifederalist, were equally indifferent to passage of Madison's amendments. Federalists continued to argue that no amendments were necessary, while antifederalists despaired that the passage of rights-related amendments would close the door to more needed amendments limiting the powers of the federal government and strengthening those of the states. ${ }^{414}$ Both federalists and antifederalists thus derided Madison's amendments as a "tub

Guarantees for freedom of speech and religion along with the right to bear arms dominated the debates of August 15. 1 ANNALS, supra note 323, at 703-49.

411. There was, of course, a very brief colloquy concerning the limitation on appeals on August 17, but this seems to have lasted but a few minutes. Id. at 755 .

It is important to note, however, that the lack of printed sources does not necessarily mean there was no debate. On the other hand, it should not be assumed that there was a lengthy debate and that the sources have not survived. On the contrary, contemporary newspapers contained extensive reports of the House debates during the relevant period. And, while they contain voluminous commentary on relatively arcane matter, such as whether to append or incorporate the amendments into the text, they contain very little discussion of any debate concerning what had become of the Seventh Amendment. Rather than conclude the histories of debates were lost, therefore, it seems more logical to assume that the lack of printed sources is a reflection of the fact that little debate was had. See THE CONGRESSIONAL REGISTER, reprinted in 11 DHFFC, supra note 309, at 1285, 1297, 1304 (containing extensive reports of House debates); GAZETTE OF THE UNITED STATES, reprinted in 11 DHFFC, supra note 309, at 1316, 1325 (same). This is because the amendments themselves were really something of an anticlimax. The right to jury trial had already been "preserved" in the judiciary bill-at least to the extent that anyone had given the matter any thought.

412. Letter from James Madison to Richard Peters (Aug. 19, 1789), in MADISON PAPERS, supra note 126 , at 347 .

413. Id.

414. Kenneth R. Bowling, Overshadowed by States' Rights: Ratification of the Federal Bill of Rights, in THE BILL OF RIGHTS: GOVERNMENT PROSCRIBED, supra note 376, at 77, 79. 
to the whale." ${ }^{415}$ The allusion was to Jonathan Swift's Tale of $a$ Tub in which he described a custom of seaman who, "when they meet a whale, ... fling him out an empty tub by way of amusement, to divert him from laying violent hands upon the ship." ${ }^{416}$ Pierce Butler described Madison's proposals as "milk-and-water amendments" designed to simply "keep [a] promise [to] his constituents." heretofore been \& still profess to be the greatest Sticklers for Amendments ... have hitherto thrown every Obstacle they could in their way $\&$. . . have endeavoured to mar their progress."

In the final analysis, it appears that few in Congress really thought there was much to be gained by taking up the subject of amendments so late in the session. By and large, the federalists acquiesced in an effort to quiet the opposition and to entice North Carolina and Rhode Island to join the union. For those with antifederalist tendencies, on the other hand, Madison's amendments did not go far enough. Men like Elbridge Gerry and Thomas Tucker appeared "determined to obstruct \& embarrass the Business as much as possible." ${ }^{419}$ The amendments were largely an attempt to gain political leverage in the ongoing effort by each side to attract supporters, and those that were finally proposed were carefully designed to obtain "the concurrence of "of both Houses" and " $3 / 4$ of the State Legislatures." "20

It is not surprising, therefore, that little debate attended what was to become the Seventh Amendment as it progressed through the Congress. The right to a jury trial had been adequately protected by the judiciary bill, and it is only in the context of the judiciary bill's provisions that we can really understand the Seventh Amendment. Although the House made several alterations to the text of the judiciary bill, none of these altered the

415. See, e.g., GazetTE OF THE UNITED STATES (N.Y.), Aug. 15, 1789, reprinted in CREATING THE BILL OF RIGHTS: THE DOCUMENTARY RECORD FROM THE FIRST FEDERAL CONGRESS 157, 175 (Helen E. Veit et al. eds., 1991) [hereinafter CREATING THE BILL OF RIGHTS] (comments of Aedanus Burke describing Madison's amendments as "little better than whip-syllabub, frothy and full of wind, formed only to please the palate, or they are like a tub thrown out to a whale"); Letter from Pacificus [Noah Webster] to James Madison, in N.Y. DAILY ADVERTISER, Aug. 17, 1789, reprinted in CREATING THE BILL OF RigHTS, supra, at 275, 276 (regretting that "Congress should spend their time in throwing out an empty tub to catch people, either factious or uninformed, who might be taken more honorably by reason and equitable laws").

416. JONATHAN SWIFT, GulliveR's TRAVELS 359 (Merritt \& Hatcher 1947).

417. Letter from Pierce Butler to James Iredell (Aug. 11, 1789), reprinted in 1 LIFE AND CORRESPONDENCE OF JAMES IREDELL 265 (Griffith J. McRee ed., 1949).

418. Frederick A. Muhlenberg to Benjamin Rush (Aug. 18, 1789), reprinted in CREATING THE BILL OF RIGHTS, supra note 415, at 280.

419. Letter from John Brown to William Irvine (Aug. 17, 1789), reprinted in CREATING THE BILL OF RIGHTS, supra note 415, at 279. For federalist opposition to the amendments, see Letter from Pacificus (Noah Webster) to Mr. Madison, in N.Y. DAILY ADVERTISER, Aug. 17, 1789, reprinted in CREATING THE BILL OF RIGHTS, supra note 415, at 175.

420. Letter from James Madison to Samuel Johnston (June 21, 1789), in MADISON PAPERS, supra note 126, at 250. 
basic economic and political compromises inherent in the judiciary bill, and none significantly affected the Senate's allocation of jury trial rights. The limitations on the jurisdiction of the lower federal courts contained in the judiciary bill helped quiet antifederalist objections to Article III. The House eventually passed the judiciary bill on September $17,{ }^{421}$ and the Judiciary Act was signed into law by President Washington on September $24,1789 .^{422}$ The amendments were approved by both Houses a few days later. Together, they set forth the basic economic and political compromise that still defines the right to jury trial in federal civil cases.

\section{OF JUSTICE STORY AND HIS CRITICS}

Antifederalist objections to the Constitution's failure to provide explicit protections for the civil jury trial were molded by their belief that the common man had not been given his rightful role in the administration of the federal government. They clearly understood that the civil jury provides an essential connection between the government and the people in ways that could not be maintained by reliance on criminal juries alone. Thus, allowing the people a role in the administration of the laws provided an important safeguard against oppression by unelected judges. One advocate of the civil jury put the case thusly:

The body of the people, principally, bear the burdens of the community; they of right ought to have a controul in its important concerns, both in making and executing the laws, otherwise they may, in a short time, be ruined. Nor is it merely this controul alone we are to attend to; the jury trial brings with it an open and public discussion of all causes, and excludes secret and arbitrary proceedings. This, and the democratic branch in the legislature, ... are the means by which the people are let into the knowledge of public affairs-are enabled to stand as guardians of each other's rights, and to restrain, by regular and legal measures, those who otherwise might infringe upon them. ${ }^{423}$

Far more was at stake than the jury's role as safeguard, however. Juries preserved republican virtues, and thus ensured the nation's integrity in a variety of ways. Civil juries "instill some of the habits of the judicial mind into every citizen." ${ }^{224}$ They spread "respect for the courts' decisions and for the idea of right throughout all classes." 225 "Juries teach men equity in practice," for each man, "when judging his neighbour, thinks that he may be judged

421. HOUSE JOURNAL, in 3 DHFFC, supra note 309, at 212.

422. Judiciary Act of 1789, 1 Stat. 73 (1789).

423. Letter XV (Jan. 18, 1788), in LETTERS FROM THE FEDERAL FARMER TO THE REPUBLICAN 97, 102-03 (Walter Hartwell Rennett ed., 1978).

424. ALEXIS DE TOQUEVILLE, DEMOCRACY IN AMERICA 252 (J.P. Mayer et al. eds., 1966).

425. Id. 
himself." "Juries teach each individual not to shirk responsibility" for one's own acts. ${ }^{427}$ Most importantly, however, "[j] uries invest each citizen with a sort of magisterial office; they make all men feel that they have duties toward society and that they take a share in its government." ${ }^{428}$ By making the citizens "pay attention to things other than their own affairs, they combat that individual selfishness which is like rust in society." clearly spoke for many when he summed up the value of the civil jury: "I do not know whether a jury is useful to the litigants, but I am sure it is very good for those who have to decide the case."

Thus, like similar declarations in state bills of rights, the Seventh Amendment is best understood as a declaration of shared, fundamental values. It declared a commitment to government of the people by ensuring that the people would always have a role in their (federal) government. Such a declaration was thought particularly necessary when the government was deliberately designed to be less responsive to pressure from the "people out of doors." In a very real sense, the Seventh Amendment's protection of jury trial rights was more than a commitment to a particular dispute resolution mechanism. It was, rather, a statement of dedication to republican principles. It ensured that the people would be represented in the judiciary to the fullest extent possible. Indeed, the right to a civil jury can be likened to the right to vote, as both are a means by which the people are vested with "the control of society." ${ }^{431}$ As de Toqueville observed, the jury has "republican character" in so far as it "puts . . . real control of affairs [of government] into the hands of the ruled ... rather than into those of the rulers." ${ }^{432}$ Thomas Jefferson expressed a similar sentiment when he commented that were he "called upon to decide whether people had best be omitted from in the Legislature or the Judiciary department, [he] would say it is better to leave them out of the Legislative[,]" for the "execution of the laws is more important than the making [of] them."

On a more practical level, the Seventh Amendment was also about allocating power between the citizenry and the unelected judiciary. In keeping with the long history of the jury as a bulwark of liberty, a function whose value was demonstrated in Entick v. Carrington ${ }^{434}$ and Wilkes v. Wood, ${ }^{435}$

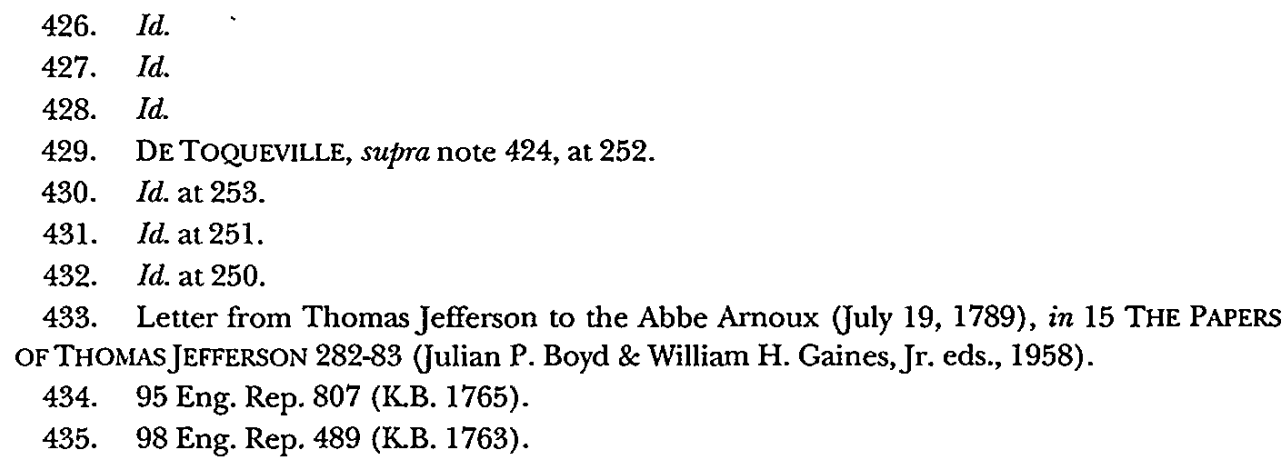


the amendment was designed to protect the "irresponsibility" of the jury and its attendant right to bring in a general verdict. Federal judges would not, therefore, be able to importune or coerce jurors to find a verdict against their conscience. In that regard the Seventh Amendment provides a defense against biased or corrupt judges. The amendment also protected the jury's right to find fact and reflected the ongoing concern that federal courts would take upon themselves the power to reverse both state and federal court juries if judges thought the jury had erred in its fact-finding function.

To be sure, although the framers of the Seventh Amendment obviously expected that both English and American practice would provide the template upon which the right to jury trial would be based, one should not lose sight of the fact that the Seventh Amendment is really about functionality. It was designed to resolve the immediate problem of how to reconcile the long-held attachment to civil juries with the reality that the jury had become something of an impediment to judicial efficiency. The need for stability in the development of the commercial law was thought to be paramount for the nation's future economic health. Yet the desire to limit the jury's role was at odds with the place that the jury had come to occupy in the American psyche. Ambiguity offered a solution to the problem. The Seventh Amendment resolved the problem of how to allay antifederalist fears about jury trial rights without cementing any particular rule into the constitutional text.

So what of Justice Story and his critics? As this Article has shown, there is little evidence that anyone in the first Congress ever understood the Seventh Amendment to refer to English law. ${ }^{436}$ More importantly, viewing the amendment in the context of the Judiciary Act of 1789 leads to exactly the opposite conclusion. Justice Story contended that Congress assented to the idea that English common-law jury practice defined the constitutional right to a civil jury trial. Yet this was the same Congress that passed the Judiciary Act, which created a set of jury trial rules at odds with that very view. After all, the Judiciary Act's provision, allowing "seizures under the laws of impost ... or trade ${ }^{\not 37}$ to be tried in federal courts without juries, was a violation of the English common-law rules, because in England such cases would have been tried in the Exchequer Court using juries. ${ }^{438}$

Given the political and economic considerations which marked the course and tenor of the debates over the Bill of Rights, the Seventh

436. Indeed, Story's assertion in Wonson is logically inconsistent, because he himself contended on other occasions that there was no way to accurately ascertain the extent to which English law was applicable to the condition of the United States. See, e.g., DeLovio v. Boit, 7 F. Cas. 418, 441-43 (C.R.D. Mass. 1815) (No. 3,776) (rejecting English limitations on American admiralty jurisdiction).

437. Judiciary Act of 1789, $\$ 9,1$ Stat. 73, 77 (1789).

438. See supra text accompanying notes 83-99, 295-301 (discussing controversy over use of vice-admiralty courts to try cases). 
Amendment is best understood as enshrining the founding generation's commitment to trial by jury without adopting any substantive rule. It is about principles not black-letter rules. No doubt the long-held assumption that Justice Story was right will cause some to hesitate. But why should the Seventh Amendment be treated differently than any other Amendment? Why should the word "preserve" have imported into the constitutional text a fixed meaning in a way that phrases such as "cruel and unusual punishments," "unreasonable searches and seizures," and "excessive bail" do not? In short, why should the Seventh Amendment be construed to have frozen our understanding of the right to trial by jury at a specific moment in time, when our understanding of the Fourth or Eighth Amendments remains more flexible? After all, the other nine amendments constituting the Bill of Rights were adopted at exactly the same time and in the same manner as the Seventh. More importantly, other than Justice Story's pronouncement in United States $v$. Wonson, ${ }^{439}$ delivered twenty years after the fact, there is nothing in the congressional record or the private letters of the participants to suggest that the Seventh Amendment was to be interpreted more restrictively than the other amendments. Moreover, there is nothing at all to suggest that practice in the English courts in 1791 was forever to serve as the yardstick by which to measure basic freedoms in the new Republic.

This is not to say that the rule Story announced in Wonson is necessarily illegitimate. On the contrary, it is certainly one way of "preserving" the right to jury trial in civil cases. However, it is not the only solution, nor is it necessarily mandated by either the text of the Constitution or the Framers' intent. In failing to provide a black-letter rule concerning juries, the founding generation left Congress and the Supreme Court free to fashion a functional approach to the use of juries in civil cases. Thus, Justice Story's "rule" is simply one way of going about the task. Admittedly, there was a great deal of merit to his approach, at least at the time Wonson was decided. Moreover, Story's rule was perfectly in keeping with his "expansive approach to judicial power" ${ }^{440}$ and, particularly, his "cry for national institutions"441 commensurate with the idea of national greatness. Story could not, after all, "tolerate the uncertainty and untidiness of the Constitution as it left the hands of the framers." ${ }^{442}$ He thus sought to use his office as a means for clarifying the law and also as a "force for rationality." bright line resolution to the problem of civil juries was consistent with Story's "effort to stimulate economic progress through law."

439. 28 F. Cas. 745 (C.C.D. Mass. 1812) (No. 16,750).

440. R. Kent NeWMYer, SUPREME COURT JUSTice JOSEPH StORY: Statesman OF THE Old REPUBLIC 114 (1985).

441. Id.

442. Id.

443. Id.

444. Id. at 116. 
should be seen as having been made on prudential grounds, however. It was one possible solution to the problem, but it may be a solution that has outlived its usefulness. As for Professor Amar's theory of dynamic conformity, it, too, is but one way of "preserving" a place for the people in their government. Although it arguably poses greater difficulties for uniformity of law and practice, there is nothing to say that the Supreme Court or Congress cannot adopt it.

It is clear, therefore, that one cannot fully grasp the full meaning of the Seventh Amendment without seeing it as part of the ongoing struggle to control the law-finding function of the American jury. Moreover, in assessing the impact of the struggle over the law-finding function, one cannot help but be struck by how economic considerations came to be at the center of the debate. The fact that the jury had become something of an obstacle to commercial success convinced many federalists of the need to find some way to restrain it. The economic compromise struck in the first Judiciary Act thus became the means for providing a measure of stability for the new national government, while still protecting the long-cherished right to jury trial in some cases. It is this compromise that is at the heart of the Seventh Amendment. Moreover, in failing to adopt any particular rules for jury trials, and more importantly, in failing to say anything about the role of the jury in the adjudicative process, the framers of the Seventh Amendment left Congress and the Supreme Court free to fashion a functional approach to the use of juries in civil cases in federal courts, without regard to the received wisdom of Justice Story. 
* * *

Heinonline -- 87 Iowa L. Rev. 234 2001-2002 